UNIVERSIDADE DE BRASÍLIA - UnB

FACULDADE DE DIREITO

TAINÁ MUNIZ CAMELO

O PAPEL DA RESPONSABILIDADE CIVIL EXTRACONTRATUAL A PARTIR DO ENFOQUE ECONÔMICO: ENTRE A PREVENÇÃO DE ACIDENTES E A COMPENSAÇÃO DA VÍTIMA 
UNIVERSIDADE DE BRASÍLIA - UnB

FACULDADE DE DIREITO

TAINÁ MUNIZ CAMELO

O PAPEL DA RESPONSABILIDADE CIVIL EXTRACONTRATUAL A PARTIR DO ENFOQUE ECONÔMICO: ENTRE A PREVENÇÃO DE ACIDENTES E A COMPENSAÇÃO DA VÍTIMA

\begin{abstract}
Monografia apresentada à Faculdade de Direito da Universidade de Brasília - UnB, como requisito parcial à obtenção de título de Bacharel em Direito.

Orientador: Prof. Doutor Othon de Azevedo Lopes
\end{abstract}




\title{
O PAPEL DA RESPONSABILIDADE CIVIL EXTRACONTRATUAL A PARTIR DO ENFOQUE ECONÔMICO: ENTRE A PREVENÇÃO DE ACIDENTES E A COMPENSAÇÃO DA VÍTIMA
}

\author{
Monografia apresentada à Faculdade de Direito \\ da Universidade de Brasília - UnB, como \\ requisito parcial à obtenção de título de Bacharel \\ em Direito. \\ Brasília-DF, 14 de dezembro de 2011.
}

\section{BANCA EXAMINADORA}

Professor Doutor Othon de Azevedo Lopes (Orientador)

Universidade de Brasília - UnB

Professora Doutora Ana de Oliveira Frazão

Universidade de Brasília - UnB

Professor Mestre Hércules Alexandre da Costa Benício

Universidade de Brasília - UnB 


\section{RESUMO}

O presente trabalho propõe uma discussão acerca do principal papel da responsabilidade civil extracontratual apontado pela teoria econômica. Entender como esse enfoque do Direito surgiu e quais são suas propostas é importante para compreender como a abordagem econômica da responsabilidade civil extracontratual estrutura o seu estudo. Valendo-se da metodologia e de alguns dos principais princípios da microeconomia, a teoria econômica fornece uma interessante análise do comportamento humano. Para os economistas, as pessoas respondem a incentivos e tal conclusão é bastante útil para avaliar o Direito e seus institutos, pois ajuda a compreender como os sujeitos reagem às regras jurídicas. A teoria econômica se propõe a analisar os incentivos criados pelo sistema de responsabilidade civil e a formular regras que contribuam para a consecução de metas socialmente relevantes, dentre eles, a prevenção de acidentes. Para tanto, construirá modelos teóricos que permitam avaliá-los. Tendo por base o exame dos incentivos proporcionados pelas regras de responsabilização, a abordagem econômica enfatizará o papel do sistema de responsabilidade civil sobre a prevenção de acidentes. Por outro lado, reservará um papel secundário à compensação da vítima, apontada pela teoria jurídica como o seu principal propósito. Este estudo analisará a função e os objetivos do mencionado instituto sob ambas as perspectivas, realçando os aspectos positivos e negativos de cada uma delas. Por fim, considerando o papel que desempenha, será questionada se sua manutenção se justifica diante dos altos custos que impõe.

Palavras-chave: Responsabilidade Civil Extracontratual. Análise Econômica do Direito. Regras de Responsabilidade Civil. Incentivos. Papel do sistema de responsabilização. Função preventiva. Função compensatória. 


\begin{abstract}
The present work proposes a discussion about the primary role of the Tort Law assumed by the economic theory. Understanding how this approach of Law emerge and what are its proposals is important to comprehend how the economic theory of Tort Law structures its study. Drawing on the microeconomics methodology and some of its main principles, such theory provides an interesting analysis of the human behavior. The economists argue that people respond to incentives and such conclusion is very useful to assess Law and its institutes because it helps to understand how the individuals react to the legal rules. The economic theory proposes an analysis of the incentives provided by the liability system and try to formulate rules that contribute to the achievement of socially relevant goals, among them, the prevention of accidents (deterrence). For that, it will build theoretical models to evaluate incentives provided by the liability rules. Based on them, the economic approach will enhance the role of the civil liability system on the prevention of accidents. On the other hand, it will reserve a secondary role to the victims' compensation, pointed out by the traditional Law theory as its primary purpose. This study will analyze the function and the goals of the mentioned institute under both perspectives and it will highlight the positives and the negatives aspects of each one. Finally, considering the role that Tort Law assumes, it will be asked if its maintenance is still necessary given the high costs it imposes.
\end{abstract}

Key-words: Tort Law. Economic Analysis of Law. Liability rules. Incentives. The role of the liability system. Deterrence. Victims' compensation. 


\section{SUMÁRIO}

INTRODUÇÃO...............................................................................................................................5

10 Enfoque Econômico do Direito ................................................................................................8 8

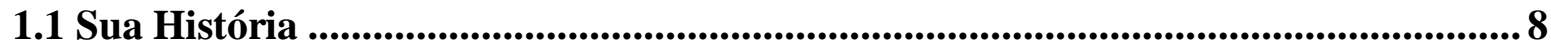

1.2 O que é a Análise Econômica do Direito? ............................................................... 11

1.2.1 Perspectivas normativa e descritiva da Análise Econômica do Direito............. 19

1.3 Críticas à abordagem econômica do Direito........................................................ 21

2 A Teoria Econômica da Responsabilidade Civil Extracontratual ................................ 22

2.1 Regras de direito de propriedade e regras de responsabilidade civil ....................23

2.2 Responsabilidade subjetiva e responsabilidade objetiva........................................ 30

3 Modelos econômicos de análise da responsabilidade civil ............................................ 36

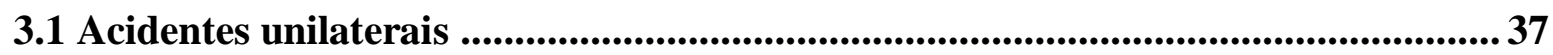

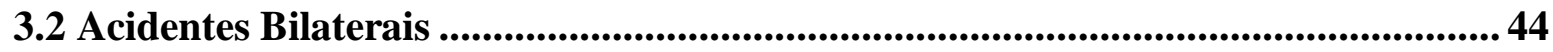

3.3 Flexibilização dos pressupostos considerados nos modelos....................................... 50

3.3.1 Nível de informação ............................................................................................ 50

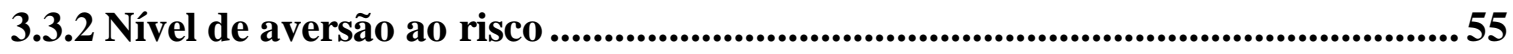

3.3.3 Custos administrativos ....................................................................................... 58

4 O papel da responsabilidade civil .................................................................................. 60

4.1 A função desempenhada pela responsabilidade civil sob a perspectiva da teoria

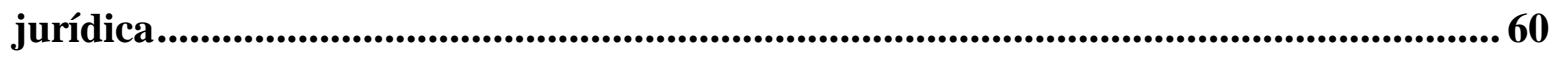

4.2 A função desempenhada pela responsabilidade civil sob a perspectiva da teoria

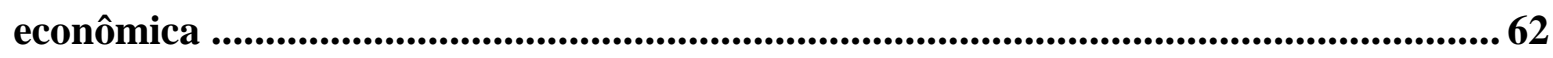

4.3 Qual é o verdadeiro propósito da responsabilidade civil? ................................... 65

4.4 A existência de um sistema de responsabilidade civil é justificável? ...................... 72

CONSIDERAÇÕES FINAIS ................................................................................. 75

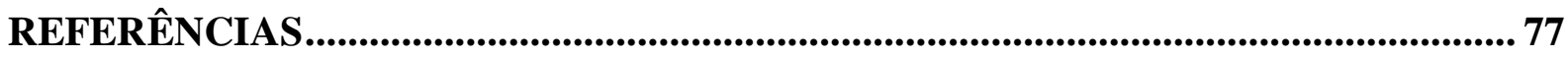




\section{INTRODUÇÃO}

A Análise Econômica do Direito (Law and Economics) se caracteriza pela aplicação das teorias e métodos econômicos à análise de instituições centrais do sistema jurídico. Embora tenha despertado o interesse de diversos estudiosos, o movimento de Direito e Economia ainda se revela tímido no Brasil.

Entender como essa abordagem do Direito surgiu e o que propõe é importante para compreender como a teoria econômica da responsabilidade civil extracontratual ${ }^{1}$ estrutura o seu estudo. No Capítulo 1, um breve histórico do movimento será esboçado, bem como serão apontadas suas principais propostas.

Tradicionalmente, a análise econômica se concentrava em questões relacionadas aos fenômenos de mercado, ou seja, restringia o seu campo de investigação a uma determinada parte da atividade humana. Contudo, desde a década de 60, a interação entre Direito e Economia tem, progressivamente, conquistado mais espaço, de modo que, atualmente, é difícil identificar qualquer domínio da atividade humana que não seja alvo de sua atenção.

A progressiva expansão do movimento, principalmente, no meio acadêmico norteamericano, conduziu a uma série de debates, que, por sua vez, permitiu a articulação de diversas pesquisas que partiam das mais variadas correntes de pensamento. Diversos campos do Direito passaram a ser objeto de estudo, dentre eles, o instituto da responsabilidade civil merece destaque.

A teoria econômica do Direito se propõe a analisar a estrutura do sistema jurídico, valendo-se da metodologia e de alguns dos principais princípios da microeconomia. Dentre eles, destacam-se a eficiência e a escolha racional. Para a Economia, tais noções são fundamentais para compreender o comportamento humano (RODRIGUES, 2007, p. 12).

Os economistas também descrevem diversas formas de "atuação racional". A que mais interessa à abordagem econômica do Direito é a de que o agente econômico, diante de uma escolha, opta por uma determinada alternativa se os benefícios esperados superam os seus respectivos custos, pois busca maximizar a utilidade que dela retira. Diante disso, a ciência econômica conclui que as pessoas respondem a incentivos, de modo que as mudanças nas circunstâncias que as cercam podem levá-las a alterar as suas escolhas, sempre de modo a maximizar seus interesses. Nesse sentido, a Economia fornece uma teoria comportamental

\footnotetext{
${ }^{1}$ No decorrer desse trabalho, a responsabilidade civil extracontratual será tratada apenas como "responsabilidade civil". É importante destacar que este instituto do Direito Privado é bastante amplo, porém, o exame se restringe às hipóteses de acidentes. Os elementos da responsabilidade civil (conduta, nexo de causalidade e dano) não serão abordados de maneira aprofundada.
} 
bastante útil para avaliar o Direito e suas instituições, pois, dentre outras coisas, ajuda a compreender como os sujeitos reagem às regras jurídicas.

A primeira parte do trabalho também tratará dos dois planos de investigação propostos pelo enfoque econômico do Direito: as abordagens descritiva e normativa. Eugênio Battesini ressalta que o ponto de distinção é o propósito de estudar o sistema jurídico como ele é e como ele deve ser (BATTESINI, 2011, p.96). A perspectiva descritiva apenas procura explicar as regras e as instituições jurídicas a partir de conceitos econômicos. A perspectiva normativa, por outro lado, procura formular regras e instituições mais adequadas em termos de bem-estar social ${ }^{2}$.

Os Capítulos 2 e 3 tratarão da análise econômica aplicada à responsabilidade civil. É importante mencionar que a teoria econômica desse campo do direito privado será abordada a partir de duas frentes de exame: a primeira parte tratará de duas distinções importantes (Capítulo 2) e a segunda tratará dos modelos econômicos (Capítulo 3).

A primeira distinção abordada será a existente entre regra de propriedade e regra de responsabilidade e será examinada apenas para fins didáticos. A superioridade entre uma e outra dependerá da existência de custos de transação. A segunda, por sua vez, diz respeito à diferença existente entre as regras de responsabilidade subjetiva e de responsabilidade objetiva.

A teoria econômica se propõe a analisar os incentivos criados pelo sistema de responsabilidade civil e a formular regras que contribuam para a consecução de objetivos socialmente relevantes, dentre eles, a prevenção de acidentes. Para tanto, construirá modelos que permitam avaliar tais incentivos, considerando cinco dimensões: o nível de precaução, o nível de atividade, o nível de informação, a distribuição dos riscos e os custos administrativos.

É importante ressaltar que os modelos teóricos são construídos a partir da adoção de um conjunto de hipóteses simplificadoras da realidade. A análise considera, por exemplo, que os acidentes envolvem apenas duas partes, autor e vítima. A partir disso, duas modalidades de acidentes serão consideradas: os unilaterais e os bilaterais. Serão unilaterais quando apenas uma das partes (geralmente, o autor) puder influenciar a probabilidade e a severidade dos danos, como nos desastres aéreos, e bilaterais quando as condutas do potencial autor e da vítima podem influir no evento danoso, como nas colisões entre motoristas e pedestres.

Todas as considerações levantadas nos capítulos anteriores serão importantes para compreender o papel da responsabilidade civil extracontratual proposto pelo enfoque

\footnotetext{
${ }^{2}$ Por exemplo, a análise normativa da responsabilidade civil se preocupa com a formulação de regras mais adequadas a consecução de determinados objetivos socialmente relevantes, como a prevenção de acidentes, a redução de seus custos, entre outros.
} 
econômico. Tendo por base o exame dos incentivos proporcionados pelas regras de responsabilização, a abordagem econômica enfatizará a atuação do sistema de responsabilidade civil sobre a prevenção de acidentes. Por outro lado, reservará um papel secundário à compensação da vítima, apontada pela teoria jurídica como o seu principal propósito. O Capítulo 4 tratará da função e dos objetivos desse instituto a partir da perspectiva econômica, mas também considerará alguns aspectos destacados pela teoria jurídica tradicional. Ambas apresentam pontos positivos e negativos. Este trabalho se propõe a analisá-los. Por fim, considerando o papel que o sistema de responsabilidade civil desempenha, será questionada se sua manutenção se justifica diante dos altos custos que impõe. 


\section{Enfoque Econômico do Direito}

\subsection{Sua História}

A relação entre Direito e Economia não é algo novo. Já foi objeto de análise dos economistas clássicos, principalmente Adam Smith, em sua obra A Riqueza das Nações (1776), em um movimento que viria a ser chamado de Iluminismo Escocês (Scottish Enlightenment). Em um momento anterior, foram encontrados alguns escritos nos quais o comportamento humano era analisado como um resultado de uma escolha racional e nos quais se discutia o cálculo dos custos e benefícios de certas políticas e regras (MACKAAY, 2000, p.68).

Nessa mesma época, David Hume já tinha uma clara compreensão das complexidades da interação humana, tal como fora articulada pela Teoria dos Jogos nos dias atuais. Ele entendia o Direito como um conjunto de convenções com as quais as pessoas aprendem a conviver a fim de viabilizar a cooperação em um mundo de escassez (MACKAAY, 2000, p.68).

Outros pensadores do final do século XVIII também apresentaram algumas reflexões sobre temas atualmente considerados parte do objeto de estudo da Análise Econômica do Direito (Law and Economics ou Direito e Economia). Entre eles, Beccaria e Bellamy merecem destaque ao tratarem do efeito dissuasivo das sanções criminais, e Bentham, ao defender que o indivíduo busca maximizar a utilidade em todas as áreas de sua vida. Contudo, não promoveram uma compreensão sistemática do Direito por meio do modelo da escolha racional (MACKAAY, 2000, p.68).

Um movimento, denominado por Mackaay de primeira onda de Direito e Economia ${ }^{3}$, ambicionava tal compreensão. Era uma corrente teórica que teve sua origem na Europa, entre os economistas, mas que alcançou os Estados Unidos por meio do movimento institucionalista. Seus pensadores mais proeminentes eram alemães, adeptos do que, posteriormente, ficou conhecida como Escola Histórica Alemã.

O principal questionamento era como a propriedade e os demais direitos eram determinados, histórica e funcionalmente, em diferentes sociedades. As respostas anteriores dadas pelos filósofos dos séculos XVI e XVII, que os direitos decorriam de uma Ordem

\footnotetext{
${ }^{3}$ Era um movimento, se assim poderia ser denominado, formado por autores vinculados à Escola Histórica Alemã, na segunda metade do século XIX, e vinculados ao movimento institucionalista norte-americano, na primeira metade do século XX.
} 
Natural, pareciam insatisfatórias, pois não explicavam as variações dos direitos no tempo e no espaço.

A tese central desse movimento era a de que as mudanças na formulação dos direitos, principalmente o de propriedade, deveriam ser encaradas como reflexo das alterações que ocorriam nas condições econômicas e sociais. Contudo, as conclusões que seus proponentes foram capazes de esboçar de seus modelos e de suas investigações históricas não convenceram os juristas.

Heath Pearson atribui o declínio do movimento conhecido como primeira onda de Direito e Economia a dois fatores principais. O primeiro seria a crescente especialização ocorrida entre os cientistas sociais, o que levou os economistas a restringir sua atenção a questões relacionadas a mercados. O segundo, diz respeito às excessivas críticas feitas ao movimento e à crescente imprecisão da metodologia econômica na qual se baseavam (MACKAAY, 2000, p.70).

Após um período de relativo afastamento, o movimento de Direito e Economia, "caracterizado pela aplicação das teorias e métodos econômicos na análise de instituições centrais do sistema jurídico" (COOTER; ULEN, 2010, p.17), começou a ganhar espaço novamente.

Por volta de 1940, na Universidade de Chicago, berço da versão contemporânea do movimento, já existia a proposta de introduzir noções de Economia no Direito, associada ao nome de Aaron Director, que fora convidado a ocupar uma cadeira na Faculdade de Direito. Director, um brilhante economista, aplicava o enfoque econômico principalmente ao Direito Antitruste, o que levou Richard Posner a destacar que:

\footnotetext{
Antes da década de 1960, a análise econômica do Direito era quase sinônimo de análise econômica do Direito Antitruste, apesar de já existirem trabalhos econômicos sobre Direito tributário (Henry Simons), Direito empresarial (Henry Manne), Direito industrial (Arnold Plant), Direito dos contratos (Robert Hale) e a regulação de transporte e outros serviços públicos (Ronald Coase e outros) (POSNER, 2003, p.23).
}

Anos mais tarde, Posner e outros autores designaram esse período de "antigo movimento" de Direito e Economia, em contraposição ao "novo movimento", que emergiu a partir da década de 60 (MACKAAY, 2000, p.72). Sua marca distintiva era a aplicação de conceitos e métodos econômicos ao sistema jurídico como um todo (campos como a responsabilidade civil; os contratos; a propriedade; os processos civil, penal e administrativo; o direito de família, entre outros). 
Um importante passo para a Análise Econômica do Direito foi a criação do Journal of Law and Economics (em 1958), que teve Aaron Director como seu primeiro editor. Posteriormente, Ronald Coase assumiu a sua posição e publicou seu artigo The Problem of Social Cost (1960), que, juntamente com os trabalhos de Guido Calabresi, Thoughts on Risk Distribution and Law of Tort (1961) e Gary Becker, Crime and Punishment: An Economic Approach (1968), viria a compor o marco teórico da proposição do paradigma contemporâneo de interação entre Direito e Economia.

Coase analisou os custos sociais e os efeitos externos das atividades econômicas, estabelecendo os limites para a análise da atribuição de direitos de propriedade e de responsabilidade. Além disso, destacou o papel da análise da relação custo-benefício no processo de tomada de decisões. Guido Calabresi, por sua vez, examinou a distribuição do risco como critério de imputação de responsabilidade por danos causados (ALVAREZ, 2006, p.52). Gary Becker foi mais longe. De acordo com o referido autor, o enfoque econômico é de tal modo abrangente que pode ser aplicado a todo e qualquer comportamento humano.

De acordo com Posner, a insistência de Becker quanto à relevância da Economia em áreas surpreendentes do comportamento não mercadológico (como a caridade, o amor e o vício), bem como as contribuições específicas para a análise econômica do crime, da discriminação racial, do casamento e do divórcio, abriu portas para o exame de temas jurídicos ainda mais amplos, não alcançados pelos estudos de Calabresi e de Coase (POSNER, 2003, p.24).

A criação do Journal of Legal Studies (1972) e a publicação do trabalho de Richard Posner, Economic Analysis of Law (1973), marcaram uma nova fase do movimento: a sua aceitação nas principais faculdades de Direito dos Estados Unidos.

O estudo de Posner foi escrito por um jurista para juristas, em uma linguagem direta e objetiva ${ }^{4}$. Já na primeira edição de sua obra, defendeu a tese de que as regras do Common Law refletiam uma certa lógica de eficiência e que, sob uma perspectiva normativa, era desejável que assim o fosse. Para ele, as normas deveriam induzir as pessoas a se comportarem de forma eficiente, não apenas nos mercados explícitos, mas em todos os domínios das interações sociais. Seu argumento central era o de que a busca por eficiência,

\footnotetext{
${ }^{4}$ Anteriormente, os trabalhos elaborados por economistas, principalmente os adeptos da economia neoclássica, predominavam. Poucos contribuintes eram juristas, dentre eles, merecem destaque Calabresi e Manne. "A participação de juristas é essencial desde que, como vimos acima, convencê-los se tornou um ponto crítico na evolução da primeira onda de Direito e Economia, um século antes. Calabresi desempenhou um papel fundamental aqui: 'a qualidade distintiva do trabalho de Calabresi demonstrou o poder de simples princípios econômicos na racionalização de todo um corpo de direito, e desenvolveu uma base coerente para a sua reforma (Veljanovski, 1990, p. 210)"” (MACKAAY, 2000, p.75).
} 
aqui ou em qualquer outra área, visa a evitar o desperdício e a maximizar a riqueza da sociedade (MACKAAY, 2000, p.76).

O programa de pesquisa de Posner era algo bastante atraente para os juristas, uma vez que o instrumental econômico neoclássico, da forma como foi apresentado em sua obra, parecia simples o suficiente para ser compreendido e aplicado aos problemas jurídicos (MACKAAY, 2000, p.77). Foi basicamente esse quadro teórico que ocupou a comunidade interessada em Direito e Economia durante a década de 70.

Anos mais tarde, o enfoque dado pela Escola de Chicago à Análise Econômica do Direito foi alvo de diversas críticas. Muitos questionavam qual a contribuição que esse movimento traria à teoria jurídica.

No entanto, os ataques à abordagem de Chicago não enfraqueceram o movimento. Alguns autores sustentam que a década de 80 pode ser descrita como a fase de seu amadurecimento e consolidação nos Estados Unidos (MACKAAY, 2000, p.80).

A progressiva expansão do movimento no meio acadêmico norte-americano, entre 1970 e 1990, conduziu a uma série de debates, que, por sua vez, permitiu a articulação de diversas pesquisas que partiam das mais variadas correntes de pensamento. Dentre elas, merecem destaque a Escola da Public Choice, as Escolas Institucional e Neo-Institucional de Direito e Economia, entre outras.

Outro fenômeno pode ser verificado a partir da década de 80: a progressiva internacionalização do movimento, bem como a criação de importantes periódicos responsáveis pela divulgação de pesquisas na área (COOTER; ULEN, 2010, p.18).

De acordo com Robert Cooter e Thomas Ulen, “o impacto do novo campo vai além das universidades, estendendo-se à prática do direito e à implementação de políticas públicas". Acrescentam que é um fenômeno tão impressionante que fez com que o professor Bruce Ackerman, da Faculdade de Direito de Yale, descrevesse a abordagem econômica do direito como "o mais importante desenvolvimento na ciência jurídica do século 20" (COOTER; ULEN, 2010, p.24).

\subsection{O que é a Análise Econômica do Direito?}

A Análise Econômica do Direito (Law and Economics ou Direito e Economia) é um movimento contemporâneo da teoria jurídica, que teve sua origem nos Estados Unidos, e que 
busca combinar as ciências econômica e jurídica a fim de formular um estudo interdisciplinar do Direito:

Análise Econômica do Direito, ou Direito e Economia, pode ser definida como "a aplicação da teoria econômica e dos métodos econométricos para examinar a formação, a estrutura, os processos e o impacto das normas e das instituições jurídicas" (ROWLEY apud MACKAAY, 2000, p.65).

Tradicionalmente, os economistas concentravam seus estudos em questões relacionadas aos fenômenos de mercado, ou seja, restringiam o seu campo de análise a uma determinada parte da atividade humana. Contudo, desde a década de 60, a Economia tem ampliado, progressivamente, o seu âmbito de investigação. Atualmente, é difícil identificar qualquer domínio da atividade humana que não seja alvo de sua atenção:

Se ainda é possível falar de um objecto da Economia, este pode talvez definir-se como sendo constituído por todos os fenômenos sociais que envolvem escolhas sobre a utilização de recursos. Inevitavelmente, muitos destes fenômenos são também estudados por outras ciências sociais (RODRIGUES, 2007, p.12).

Vasco Rodrigues sustenta que a Economia não se distingue tanto por seu objeto, mas, principalmente, por seu método. Este consistiria em três princípios básicos: 1) as pessoas fazem escolhas e atuam de forma racional; 2) os comportamentos coletivos podem ser deduzidos das escolhas individuais, a partir do conceito de equilíbrio; e 3) a eficiência é, no plano normativo, o critério fundamental para avaliar o comportamento humano (RODRIGUES, 2007, p. 12).

A necessidade de escolha decorre do confronto entre recursos limitados e desejos potencialmente ilimitados dos agentes econômicos. A escolha racional consiste em encontrar a alternativa que melhor satisfaça esses desejos, dadas as limitações que enfrentam.

Os economistas descrevem três formas de "atuação racional". A primeira diz respeito à consistência das escolhas. Os atores econômicos contam com um conjunto de preferências estáveis e pré-determinadas que lhes permite determinar se, diante de duas alternativas que lhes são apresentadas, prefere a primeira à segunda ou se ambas lhes são indiferentes. Também lhes permite optar entre alternativas situadas em momentos distintos (é preferível cortar uma árvore hoje para fazer lenha ou esperar que cresça e dê frutos?) e entre as que envolvam incerteza (é preferível aplicar minhas economias em uma poupança de rendimento certo, ou em ações que tanto podem valorizar substancialmente como perder todo o seu valor?). Sob este contexto, "atuar de forma racional" significa que, se o agente econômico prefere A a B e tem que escolher uma das opções, escolherá A. 
A segunda forma de "atuação racional" considera que cada escolha proporciona ao agente econômico uma determinada utilidade e que ele é capaz de ordenar as diversas alternativas que lhe são oferecidas a partir da utilidade que lhe proporcionam. Tendo que escolher entre duas opções, o indivíduo racional escolhe a que the proporciona maior utilidade $^{5}$. Posner sustenta que o homem se esforça para maximizá-la em todas as áreas de sua vida, não só quando se ocupa de assuntos "econômicos" 6 .

De acordo com Vasco Rodrigues, tais considerações levam a crer que a Economia pressupõe que as pessoas são egoístas, na medida em que admite que elas fazem suas escolhas pensando apenas na maximização de sua utilidade individual. No entanto, salienta que não há qualquer questionamento:

[...] sobre o que determina a utilidade de cada agente econômico. É perfeitamente compatível com todas as considerações anteriores que a utilidade, a satisfação, que um agente econômico retira de uma determinada situação seja, parcialmente, ou até na totalidade, determinada pela satisfação que julga proporcionar aos outros: o altruísmo não é incompatível com a escolha racional. Como não o é, igualmente, a maldade (um indivíduo pode obter utilidade com o sofrimento dos outros) ou qualquer outra característica psicológica que afecte aquilo que proporciona utilidade ao agente econômico (RODRIGUES, 2007, p.16).

Outro ponto merece destaque: assumir que os sujeitos atuam de forma racional não quer dizer que sejam racionais ${ }^{7}$. É importante salientar que a maximização racional não pode ser confundida com cálculo consciente. O comportamento é racional quando se conforma ao modelo da eleição racional, qualquer que seja o estado mental de quem faz a escolha, ou seja, o pressuposto diz respeito ao comportamento e não especificamente aos processos mentais que o originam (POSNER, 2003, p.3).

A terceira forma de "atuação racional" descrita pelos economistas alude ao fato de que, diante de uma escolha, o agente econômico opta por uma determinada alternativa se os benefícios esperados superam os seus respectivos custos. Entende-se por benefício qualquer acréscimo de utilidade para agente econômico e custo qualquer decréscimo dela.

Em rigor, custo é o benefício de que se abdica ao escolher uma determinada alternativa. Para os economistas, custo é "custo de oportunidade". Por exemplo, o custo da

\footnotetext{
${ }^{5}$ A utilidade, tal como empregada pelos economistas, é um termo técnico que indica a satisfação que o indivíduo obtém de uma dada situação. Contudo, é importante salientar que não tem uma conotação exclusivamente material, pois é possível, por exemplo, obtê-la com a observação de uma obra de arte (RODRIGUES, 2007, p.13).

${ }^{6}$ De acordo com Richard Posner, a tarefa da Economia consiste na exploração das implicações de se supor que o homem procura, de forma racional, aumentar ao máximo seus fins na vida, suas satisfações, o que ele chama de "interesse próprio". Acrescenta que, a fim de evitar qualquer confusão, os economistas preferem falar em "utilidade" antes de falar em "interesse próprio".

7 "Note-se que o princípio da escolha racional assenta na avaliação que cada indivíduo faz da utilidade que retira de cada situação, com a informação e a capacidade cognitiva de que dispõe. O facto de alguém fazer escolhas que parecem irracionais a quem dispõe de mais informação ou de maior capacidade para tratar a informação não viola este princípio. Um indivíduo que escolhe gastar o seu dinheiro em cocaína, em vez de comprar os medicamentos de que necessita, não está necessariamente a violar o princípio da escolha racional: dada a sua apreciação pessoal da situação, o indivíduo pode entender que a cocaína lhe proporciona mais utilidade do que os medicamentos". (RODRIGUES, 2007, p. 12)
} 
educação superior são os salários que o estudante deixa de ganhar por estar assistindo às aulas ao invés de estar trabalhando.

Posner destaca que essa discussão sobre custo ajuda a afastar uma das "falácias mais tenazes" acerca da Economia: que se ocupa apenas com dinheiro. Pelo contrário, ela trata do uso de recursos, o dinheiro é meramente uma unidade de referência objetiva. O economista distingue as transações que afetam o uso dos recursos, independentemente da transferência de dinheiro, das transações puramente pecuniárias. O trabalho doméstico, por exemplo, é uma atividade econômica, ainda que quem trabalhe em casa seja um cônjuge que não recebe qualquer compensação financeira, se tal atividade envolve um custo: o custo de oportunidade é o tempo de quem trabalha em casa (POSNER, 2003, p.6).

A aplicação mais famosa do conceito de custo, na Análise Econômica do Direito, é o Teorema de Coase. De maneira simplificada, o teorema enuncia que, se os custos de transação são iguais a zero, a atribuição inicial de um direito de propriedade não afetará o uso final desta $^{8}$.

Todas essas proposições acerca do homem como um maximizador racional de utilidades, diante das escolhas que faz, implicam dizer que as pessoas respondem a incentivos. As mudanças nas circunstâncias que as cercam podem levá-las a alterar as suas escolhas, sempre de modo a maximizar as suas satisfações.

As pessoas, por exemplo, reagem à modificação de preços, o que explica o mecanismo da Lei da demanda. Se o preço de um produto aumenta, o consumidor, sendo racional e interessado em si mesmo, reagirá investigando a possibilidade de substituí-lo por outros produtos. O resultado será uma diminuição da quantidade de consumidores interessados em comprá-lo, ou seja, um aumento de preço resulta na diminuição da quantidade demandada.

A lei da demanda não atua somente sobre bens com preços explícitos. Diz-se que o criminoso condenado que cumpriu a sua sentença "pagou a sua dívida perante a sociedade". Tal metáfora faz muito sentido para um economista, pois, para ele, a pena é o "preço" cobrado

\footnotetext{
${ }^{8}$ Suponhamos que um fazendeiro é proprietário de uma terra e que tal direito lhe confere a faculdade de impedir a destruição de sua plantação por faíscas decorrentes dos trilhos de trem adjacentes. Para ele, sua plantação vale \$100. Considere que o uso desimpedido dos trilhos de trem, ou seja, o direito de livre passagem, é muito mais valioso. Por um custo de \$110, contudo, a companhia ferroviária pode instalar um equipamento para conter as faíscas, o que eliminaria o perigo de queimada. Desse modo, os trens poderiam percorrer o quanto quisessem sem prejudicar a plantação do fazendeiro. Com base nessa suposição, o valor real da plantação para o fazendeiro é alguma soma entre \$100 e \$110, já que, por qualquer preço inferior a \$110, a companhia ferroviária preferiria comprar o direito de propriedade do fazendeiro ao invés de instalar o equipamento para conter faíscas (que teria um custo superior). O fazendeiro venderá a sua terra, que, então, será transformada em uma área destinada a algum uso que não esteja sujeito a eventuais queimadas (assim como teria feito o dono dos trilhos se fosse o proprietário inicial das terras). Se, por outro lado, o responsável pela ferrovia detivesse o uso irrestrito de seu direito de passagem, mas a plantação do fazendeiro fosse mais valiosa que o bloqueador de faíscas (e gerasse mais riqueza que o transporte ferroviário), o fazendeiro compraria o direito de uso de suas terras livres de possíveis danos ocasionados por faíscas e novamente a propriedade seria destinada a seu uso mais produtivo (POSNER, 2003, p.7).
} 
pela sociedade por uma ofensa criminal ${ }^{9}$. Os economistas chamam os preços não pecuniários de "preços de sombra" (shadow prices) ou preços implícitos (POSNER, 2003, p.5).

O segundo princípio da análise econômica, o princípio do equilíbrio, diz respeito à forma como as interações sociais determinam as alternativas a serem escolhidas. Por exemplo, o comportamento racional pode surgir como resultado de processos de aprendizagem e seleção:

\begin{abstract}
Os economistas tendem a admitir que, embora cada empresa possa não estar especificamente determinada em conseguir o máximo lucro, ao longo do tempo as empresas cujo comportamento é mais consentâneo com esse desiderato tendem a prosperar e a crescer enquanto que as que dele se desviam tendem a perder importância e a desaparecer. Por isso, o comportamento colectivo das empresas tenderia a ser semelhante ao que resultaria da maximização deliberada do lucro (RODRIGUES, 2007, p.15).
\end{abstract}

O exercício de autoridade e a livre negociação (ou mercado) são as duas formas de interação social que interessam à Economia. A autoridade, que permite a alguém ditar unilateralmente o resultado de uma interação, desempenha um papel importante na sociedade, principalmente no se refere à decisão acerca da alocação dos recursos disponíveis. O mercado, por sua vez, é a designação econômica para um arranjo institucional que determina a utilização de certo recurso a partir da livre negociação entre os que o detêm e os que estão interessados em obtê-lo (RODRIGUES, 2007, p.19). É sobre essa forma de interação que o princípio do equilíbrio é diretamente aplicável.

Para terem acesso a determinado recurso, os potenciais compradores terão que pagar um preço por ele. Diante do princípio da escolha racional, o comprador só terá interesse em adquiri-lo se o custo (o que irá pagar por ele) não exceder o benefício que espera retirar de sua utilização. Nesse sentido, o preço funcionará como incentivo que levará o agente a comprar o recurso ou a deixar de fazê-lo.

O preço que o comprador está disposto a pagar por uma determinada unidade do recurso funciona como uma medida monetária de sua utilidade. Em geral, um recurso não tem a mesma utilidade para todos os seus potenciais interessados ${ }^{10}$. Logo, se for muito elevado, apenas os potenciais compradores para os quais o recurso tem maior utilidade estarão dispostos a pagar. Em contrapartida, à medida que o preço diminui, o número de potenciais compradores para os quais a utilidade proporcionada pelo recurso justifica o seu pagamento

\footnotetext{
${ }^{9}$ O economista prevê que um aumento da severidade de uma sanção ou da probabilidade de sua imposição elevará o preço do delito e, portanto, reduzirá a sua incidência (POSNER, 2003, p.5).

${ }^{10}$ Nesse sentido, um carro será mais útil para quem mora longe de seu local de trabalho do que para quem mora apenas a 50 metros dele.
} 
irá aumentar. Nisto consiste a lei da demanda: quanto menor o preço de um bem, maior será a quantidade de pessoas interessadas em comprá-lo.

Tal como ocorre com os compradores, um recurso não terá a mesma utilidade para todos os potenciais vendedores. Por isso, se o preço for baixo, somente aqueles para os quais o recurso tem pouca utilidade é que estarão dispostos a vendê-lo. Entretanto, à medida que o preço sobe, o número de potenciais vendedores para os quais o benefício decorrente da venda (o preço recebido) supera o seu respectivo custo (a perda da utilidade proporcionada pelo recurso) aumenta.

Portanto, em um mercado em que compradores e vendedores podem negociar livremente, a sua interação tenderá a originar um preço para o qual a quantidade oferecida será igual à quantidade demandada. Desse modo, os preços criam o incentivo para que as escolhas de consumidores e produtores se ajustem mutuamente. Diz-se que o mercado estará em equilíbrio ${ }^{11}$.

Para os economistas, modelos como o da oferta e da demanda ajudam a compreender e a explicar inúmeros fenômenos da vida social. De acordo com eles, a unidade de análise fundamental são as escolhas feitas pelos indivíduos, de maneira que os comportamentos coletivos são analisados como resultado de um conjunto de escolhas individuais.

Ainda sobre o tema, Posner destaca que, por meio das transações voluntárias (mercado), os recursos tendem a se deslocar em direção a usos aos quais os agentes econômicos atribuem maior valor, que, por sua vez, será medido a partir de sua disposição para obtê-los ${ }^{12}$. Por que o fazendeiro A se dispõe a comprar a fazenda de B por um preço maior que o valor mínimo que B atribui a sua propriedade? Porque a propriedade vale mais para A do que para B. De acordo com ele, isso significa que A pode usá-la para produzir bens mais valiosos, uma vez que está disposto a pagar mais para obtê-la.

Posner conclui que, quando um recurso é utilizado em sua destinação mais valiosa, de modo que, uma nova realocação não aumentaria o seu valor, então, está sendo empregado de forma eficiente.

Tal discussão introduz um conceito fundamental para a Economia: a eficiência. Os economistas a descrevem de diversas maneiras. A primeira delas é a eficiência produtiva, que

\footnotetext{
${ }^{11}$ Cooter e Ulen destacam que "os economistas geralmente pressupõem que as interações tendem ao equilíbrio, independentemente de ocorrerem em mercados, eleições, clubes, jogos, equipes, empresas ou casamentos" (COOTER; ULEN, 2010, p.37). Quanto ao equilíbrio do mercado, sustentam que é, "em termos de bem-estar, um resultado tão desejável que seria útil conhecer as condições sob as quais ele irá vigorar. Sem entrar em detalhes, a condição essencial é que todos os mercados sejam competitivos". Quatro situações podem comprometer esse equilíbrio: monopólio e poder de mercado; externalidades; bens públicos e assimetria informacional grave (COOTER; ULEN, 2010, p.61).

${ }^{12} \mathrm{O}$ valor econômico de um bem é quanto alguém está disposto a pagar para obtê-lo ou, se já o tem, quanto pede para dele se desfazer. É importante ressaltar que nem sempre os valores são os mesmos nas duas situações. (POSNER, 2003, p.10)
} 
significa produzir mais com menos insumos ou com insumos mais baratos. A eficiência técnica, por sua vez, diz respeito ao desenvolvimento de tecnologia capaz de melhorar a produção (produzir mais com uma mesma combinação de insumos).

Contudo, a eficiência que interessa à Análise Econômica do Direito é a alocativa, também chamada de eficiência ou melhoria de Pareto, que se associa à ideia de satisfação de preferências pessoais:

\begin{abstract}
Diz-se que determinada situação é Pareto eficiente ou alocativamente eficiente se é impossível mudá-la de modo a deixar pelo menos uma pessoa em situação melhor (na opinião dela própria) sem deixar outra em situação pior (mais uma vez, em sua própria opinião). Para fins de simplificação, suponhamos que haja apenas dois consumidores, Smith e Jones, e dois bens, guarda-chuva e pão. Inicialmente, os bens estão distribuídos entre eles. Essa alocação é Pareto eficiente? Sim, se é impossível realocar o pão e o guarda-chuva de modo a deixar ou Smith ou Jones em situação melhor sem deixar o outro em situação pior (COOTER; ULEN, 2010, p.38).
\end{abstract}

Considere a possibilidade de alterar uma determinada situação, por exemplo, a legislação em vigor. Esta alteração será considerada uma melhoria de Pareto se beneficia, pelo menos, uma pessoa sem prejudicar ninguém. Quando isso ocorre, diz-se que a situação resultante da alteração é superior à situação inicial ou mais eficiente. Vasco Rodrigues salienta que este parece ser o critério menos subjetivo para comparar duas situações, pois seria necessário apenas saber se cada um dos indivíduos potencialmente afetados considera que a mudança o beneficiou ou o prejudicou.

Se depois de uma primeira melhoria de Pareto for possível aumentar a utilidade de uma pessoa sem prejudicar ninguém, esta segunda alteração configurará uma nova melhoria de Pareto, e assim por diante. Entretanto, inevitavelmente, após uma sucessão de melhorias de Pareto, atinge-se a situação em que já não é possível aumentar a utilidade de alguém sem prejudicar outrem. Estar-se-á, então, diante de um ótimo de Pareto ${ }^{13}$.

Contudo, os conceitos de Pareto não permitem hierarquizar duas situações Paretoeficientes, pois envolveria um juízo sobre a importância relativa dos custos e benefícios que os sujeitos envolvidos retiram de cada uma delas, ou seja, haveria uma comparação interpessoal $^{14}$. Não há, portanto, uma forma objetiva de fazer tal comparação.

Posner sustenta que o critério de Pareto enfrenta diversas limitações, dentre elas, a sua pouca aplicação no mundo real, uma vez que a maioria das transações tem efeitos sobre

\footnotetext{
13 “Dizer que uma situação é Pareto-eficiente, é um óptimo de Pareto, não é o mesmo que dizer que é justa, boa ou correcta. Por exemplo, se duas pessoas famintas tiverem que distribuir entre si dois quilos de arroz e uma se apoderar de toda comida, a situação resultante é um óptimo de Pareto: não é possível aumentar a satisfação da pessoa que não recebeu arroz sem prejudicar a da que dele se apropriou. No entanto, presumivelmente, a maioria das pessoas não considerariam esta distribuição justa”. (RODRIGUES, 2007, p. 27)

${ }^{14}$ Considere o exemplo dado na nota anterior. Comparando as situações em que uma pessoa se apropria de todo o arroz e em que este é dividido por igual entre os dois famintos, só é possível dizer se a segunda é preferível à primeira se considerarmos que o quilo de arroz dado à pessoa que não tinha nenhum proporciona maior utilidade do que à pessoa dele privada.
} 
terceiros. Considerando o fato de que as condições para que seja evidenciada uma melhoria de Pareto quase nunca são satisfeitas, o referido autor conclui que tal definição operativa de eficiência não deve ser empregada pela Economia (POSNER, 2003, p.13).

Insatisfeitos, os economistas desenvolveram um novo critério: a melhoria potencial de Pareto ou eficiência de Kaldor-Hicks. Considere a situação em que há uma mudança que beneficia alguns e prejudica outros. Existe, no entanto, uma compensação suficiente para que os prejudicados concordem com a alteração. De acordo com o critério de Kaldor-Hicks, tal modificação seria considerada uma melhoria se os que dela se beneficiam estiverem interessados em implementá-la ainda que tenham que compensar os eventuais prejudicados:

[...] uma melhoria potencial de Pareto permite mudanças em que haja tanto ganhadores quanto perdedores, mas exige que os ganhadores ganhem mais do que os perdedores perdem. Se essa condição for cumprida, os ganhadores podem, em princípio, indenizar os perdedores e ainda ter um excedente que sobre para eles mesmos. Para uma melhoria potencial de Pareto, a indenização não precisa ser feita efetivamente, mas tem de ser possível em princípio. Esta é, essencialmente, a técnica da análise de custo-benefício. Na análise custo-benefício, um projeto é empreendido quando seus benefícios excedem seus custos, o que implica que os ganhadores poderiam compensar os perdedores (COOTER; ULEN, 2010, p. 64).

É importante salientar que, para a satisfação do critério de Kaldor-Hicks, não é necessário que os beneficiados compensem efetivamente os prejudicados, mas apenas que estejam dispostos a fazê-lo, se isso fosse necessário para garantir a mudança. Portanto, se os benefícios obtidos com a alteração superarem os seus respectivos custos e se fosse viável uma negociação entre os beneficiados e os prejudicados, aqueles poderiam indenizar estes por seus prejuízos. Fala-se, então, em um ganho de eficiência.

Saber se é possível dizer com confiança se uma transação voluntária é eficiente e em que medida é um das principais preocupações da Análise Econômica do Direito. Quando os recursos são transferidos por meio de transação voluntária, é bem provável que essa alocação envolveu um aumento de eficiência, pois não teria ocorrido se ambas as partes não esperassem uma melhoria de sua situação. Isso implica que os recursos transferidos são mais valiosos nas mãos dos seus novos donos ${ }^{15}$.

Contudo, muitas das transações afetadas ou efetuadas pelo sistema jurídico são involuntárias. A maioria dos crimes e dos acidentes são transações involuntárias, o mesmo ocorre com a condenação ao pagamento de uma multa ou indenização. Como saber quando há um aumento de eficiência em tais situações? Posner sustenta que, se considerarem que uma transação antes de ser eficiente deve ser voluntária (verdadeiramente voluntária, em que todos

\footnotetext{
${ }^{15}$ Para Posner, o termo "eficiência" sempre será empregado para denotar a alocação de recursos em que o seu valor é maximizado.
} 
os envolvidos, inclusive os prejudicados, foram plenamente compensados), haverá poucas ocasiões para formular um juízo de eficiência, porque poucas serão voluntárias nesse sentido. Uma abordagem alternativa consistiria em adivinhar se a transação teria ocorrido se fosse viável. Este enfoque trataria de reconstruir os termos prováveis de uma transação de mercado em circunstâncias nas quais ocorreu, na verdade, uma transação forçada, em outras palavras, simularia o mercado ${ }^{16}$.

Diante do que foi exposto, pode-se concluir que a Economia fornece uma teoria comportamental bastante útil para avaliar o Direito e suas instituições, pois, dentre outras coisas, ajuda a compreender como os sujeitos reagem às regras jurídicas.

A Análise Econômica do Direito nada mais é do que a análise do Direito à luz dos princípios enunciados. Para compreendê-la melhor, será necessário conhecer as duas abordagens propostas pela teoria econômica do Direito: a descritiva e a normativa.

\subsubsection{Perspectivas normativa e descritiva da Análise Econômica do Direito}

Vasco Rodrigues sustenta que, onde há escolhas a serem feitas, existe a possibilidade de aplicação da teoria econômica. Há, certamente, no Direito, muitas escolhas a serem analisadas: Por que os legisladores escolhem fazer uma lei com um determinado conteúdo? Por que, dado o conteúdo de uma lei, alguns indivíduos escolhem respeitá-la e outros não?

A Análise Econômica do Direito tem buscado responder a dois tipos de questões: 1) Quais são os efeitos de um determinado enquadramento jurídico?; e 2) Qual o enquadramento jurídico deveria existir?

O primeiro questionamento parte de uma abordagem descritiva (o que é). Posner define o enfoque descritivo ou positivo da Análise Econômica do Direito como aquele que tenta explicar as regras e os resultados jurídicos tal como são, ao invés de tentar mudá-los para torná-los melhores (POSNER, 2003, p.25). Tal perspectiva decorre diretamente da definição de Economia como o estudo da escolha racional.

De acordo com os economistas, as escolhas feitas pelas pessoas são influenciadas pelos sistemas de incentivo a que estão sujeitas, pois alteram os custos e os benefícios das

\footnotetext{
16،'Se, por exemplo, a pergunta for 'a água limpa é mais valiosa como insumo na produção de papel ou na navegação?', nós poderemos tentar determinar, usando qualquer quantitativo ou outro dado que possa nos ajudar, se, em um mundo de custos de transação iguais a zero, a indústria produtora de papel compraria dos navegadores o direito de usar a água limpa". (POSNER, 2003, p.16)
} 
opções disponíveis. Por exemplo, se determinado comportamento é proibido e punido, a sua relação custo-benefício se torna menos atrativa do que se não o fosse ${ }^{17}$.

Nesse sentido, a lei pode ser encarada como um sistema de incentivos. Analisar os efeitos de diferentes sistemas de incentivos é uma das grandes preocupações da Análise Econômica do Direito.

O segundo questionamento, por sua vez, parte de uma abordagem normativa (o que deveria ser), que diz respeito à conveniência social de certas normas. Este enfoque decorre da preocupação dos economistas com a eficiência. Diferentes sistemas de incentivos e, portanto, diferentes enquadramentos legais, não são igualmente eficientes, de modo que, um regime jurídico mais eficiente é preferível a um menos eficiente ${ }^{18}$.

Posner defende que, embora o economista não possa dizer à sociedade se deve buscar limitar o roubo, pode demonstrar que seria ineficiente permitir roubos ilimitados. Assim, ele esclarece um conflito de valores, demonstrando quanto de um valor, a eficiência, pode ser sacrificado para que outro seja alcançado (POSNER, 2003, p.24). Ou, considerando a meta de limitação de roubo, o economista deve ser capaz de demonstrar que os meios adotados para a consecução de tal objetivo são ineficientes. Se os métodos mais eficientes não prejudicam outros valores, então, seriam socialmente desejáveis, ainda que a eficiência não ocupe uma posição relevante na escala de valores sociais.

O referido autor ressalta que a análise descritiva evidenciará que muitos campos do Direito caminham em direção à eficiência. Já a análise normativa, que se associa à teoria da eficiência $^{19}$, não afirma que as normas jurídicas e as decisões judiciais sejam eficientes. Isso seria muito improvável, principalmente diante da dificuldade das questões com as quais o Direito tem que lidar. Tal enfoque sustenta que o sistema jurídico pode ser explicado de maneira melhor como um sistema de maximização de riqueza social ${ }^{20}$. Posner aponta que direito constitucional, por exemplo, quando comparado com o direito comum, tem menos chances de promover a eficiência, mas mesmo esse campo está impregnado de preocupações econômicas e iluminado pela análise econômica do direito ${ }^{21}$ (POSNER, 2003, p.25).

\footnotetext{
${ }_{17}^{17} \mathrm{O}$ enfoque descritivo questionaria a influência de um regime de responsabilidade civil sobre o número de acidentes, entre outras coisas.

${ }^{18}$ Não deveríamos preferir um regime justo a um injusto?

${ }^{19}$ A "teoria econômica do direito" não pode ser confundida com a "teoria da eficiência do direito comum". A primeira trata de ex plicar o maior número possível de fenômenos jurídicos por meio do uso da Economia. A segunda, que está incluída naquela, postula uma meta econômica específica para um conjunto de regras e instituições jurídicas (POSNER, 2003, p.26).

${ }^{20} \mathrm{Na}$ verdade, Steven Shavell sustenta que a avaliação de políticas públicas e das regras jurídicas terá por referência uma medida de bemestar social, que será determinada a partir dos anseios de uma sociedade. Para Posner e seus seguidores, o parâmetro para a análise normativa será a maximização de riqueza, mas poderia ser qualquer outro. Para Shavell, o bem-estar social "is assumed to be a function of individuals" well-being, that is, of their utilities" (SHAVELL, 2003, Capítulo 1-p.2).

${ }^{21}$ Alguns autores não concordam com essa afirmação. De acordo com eles, a noção de eficiência se vincula à ética utilitarista, que é alvo de constantes críticas por não dar tanta relevância ao reconhecimento de direitos individuais.
} 
Tanto o aspecto normativo quanto descritivo da Análise Econômica do Direito têm sido alvos de constantes críticas. É importante conhecê-las para compreender melhor as propostas da teoria econômica do Direito.

\subsection{Críticas à Análise Econômica do Direito}

Posner destaca duas frentes de ataque: os que atacam o aspecto positivo da teoria econômica do direito (o Direito pode ser compreendido de maneira melhor a partir da noção de eficiência) e os que atacam o aspecto normativo (o Direito deve se ajustar ao máximo a essa noção).

Ronald Dworkin é autor de diversas críticas à Análise Econômica do Direito. Seu principal alvo é o aspecto normativo da teoria, embora também sustente que as suas falhas normativas são tão significativas que lançam dúvidas sobre suas pretensões descritivas.

No entanto, o cerne de toda a crítica dworkiana se concentra na ideia, sustentada por Posner, de que a maximização de riqueza é um valor social genuíno e que deve orientar as decisões judiciais ${ }^{22}$. Segundo Dworkin, tal proposição admite muitas variações e seus defensores não foram tão claros quanto a qual delas desejam promover, de modo que qualquer discussão detalhada sobre o tema deve considerar possibilidades diferentes, com nuances razoavelmente amplas.

Quanto ao argumento de que não se preocupa com a justiça ou com a equidade, os defensores do movimento asseveram que esses conceitos assumem significados muito mais amplos para a Análise Econômica do Direito. Aduzem que o termo "justiça", por vezes, é compreendido como justiça distributiva ${ }^{23}$, mas que também pode assumir o sentido de eficiência, tal como a teoria a descreve.

Por fim, Dworkin sustenta que o critério de Kaldor-Hicks deve ser interpretado de modo a levar em conta a quantidade de bem-estar conquistada ou perdida, bem como o

\footnotetext{
${ }^{22}$ É uma crítica que se direciona principalmente à proposta de Posner. Dworkin alega que não está claro por que a riqueza social é um objetivo digno. Questiona por que alguém pensaria que uma sociedade que tem mais riqueza, tal como definida, é melhor ou está em melhor situação que uma sociedade que tem menos. Ele aponta algumas respostas possíveis a essa pergunta: "(1) Pode-se pensar que a riqueza social é, ela própria, um componente do valor social - isto é, algo que por si só vale a pena ter. Há duas versões para essa afirmação. (a) A versão imodesta sustenta que a riqueza social é o único componente do valor social. Argumenta que o único aspecto em que uma sociedade pode ser melhor ou estar em melhor situação que outra é o da riqueza social. (b) A versão modesta argumenta que a riqueza social é componente entre outros do valor social. Uma sociedade, pro tanto, é melhor que outra se tem mais riqueza, mas pode ser pior, de modo geral, quando outros componentes são levados em conta, inclusive componentes de distribuição. (2) Pode-se pensar na riqueza social não como um componente, mas como um instrumento de valor. As melhoras na riqueza social não são valiosas em si mesmas, mas valiosas porque podem ou irão produzir outras melhoras que são valiosas em si" (DWORKIN, 2000, p.356).

${ }^{23}$ Justiça distributiva se preocupa com a forma com que os recursos são distribuídos em sociedade.
} 
número dos que ganham ou perdem, sob pena de converter-se em um critério utilitarista ${ }^{24}$. Contudo, quando tal variável (quantidade de bem-estar conquistada ou perdida) é introduzida, surgem os problemas de comparações interpessoais de utilidade e, de acordo com ele, "esse é o buraco da agulha, se a utilidade pode passar por esse buraco, ganha o céu" (DWORKIN, 2000, p.424).

Alguns autores propõem como alternativa para superar as dificuldades inerentes às comparações interpessoais converter as utilidades subjetivas em valores monetários que os indivíduos considerem equivalentes (converteria uma escala subjetiva em uma objetiva). No entanto, trata-se de uma solução imperfeita, uma vez que a utilidade marginal do dinheiro é decrescente ${ }^{25}$.

Outras objeções se direcionam ao aspecto descritivo. Muitos críticos afirmam que tal enfoque não pode ser realmente testado, pois os dados para a formação de um juízo quanto a se uma decisão ou regra jurídica é ou não eficiente são impossíveis de serem obtidos. Acrescenta-se o fato de que algumas das doutrinas ditas eficientes, na verdade, não o são. Em resposta, Posner destaca que dados necessários para testar a teoria positiva, como no caso da responsabilidade civil extracontratual (quantidade de acidentes, custos em ações judiciais, nível dos prêmios de seguros), podem ser obtidos:

O que é verdade, contudo, é que poucos testes estatísticos foram aplicados à teoria econômico-positiva do direito, e que, ao contrário, os analistas tem se dado por satisfeitos em fazer uma avaliação qualitativa das propriedades de maximização da riqueza das regras, doutrinas e decisões jurídicas em estudo (POSNER, 2007, p. 498).

Posner ressalta que muitas são as fraquezas e que não podem ser ignoradas. No entanto, um dos méritos pedagógicos da Análise Econômica foi alertar os juristas para a "possibilidade de se teorizar cientificamente sobre o direito, desafiando-os a procurar novas teorias" (POSNER, 2007, p.501), bem como que um estudo interdisciplinar tem muito a oferecer à teoria jurídica. Alguns campos do direito têm se mostrado mais receptivos a essa nova proposta, dentre eles, a responsabilidade civil merece destaque.

\footnotetext{
${ }^{24}$ Caso contrário, prejuízos devastadores para alguns poucos poderiam ser justificados diante de lucros triviais para a maioria (DWORKIN, 2000, p. 424).

${ }^{25} \mathrm{O}$ acréscimo de satisfação proporcionado pelo primeiro real tende a ser maior do que o proporcionado pelo segundo e assim por diante. $\mathrm{O}$ que significa simplesmente que quanto mais dinheiro se tem, menos satisfação adicional será obtida com outra unidade de dinheiro. Ou seja, um real significará menos para uma pessoa à medida que sua riqueza aumenta. A utilidade marginal decrescente é ilustrada mais claramente com bens menos versáteis que o dinheiro.
} 


\section{A Teoria Econômica da Responsabilidade Civil Extracontratual}

A responsabilidade civil extracontratual é "um dos primeiros campos do direito privado analisado com sucesso mediante a utilização de modelos econômicos formais" (COOTER; ULEN, 2010, p. 324). Nos últimos anos, o interesse por esse tema tem ganhado espaço, principalmente, diante do aumento do número de acidentes.

A abordagem econômica da responsabilidade civil se propõe a analisar a estrutura do sistema jurídico, a fim de formular regras que contribuam para a consecução de objetivos socialmente relevantes, dentre eles, a prevenção de acidentes ${ }^{26}$. Para tanto, construirá modelos que permitam avaliar os incentivos proporcionados pelas regras de responsabilidade civil, em especial, pelas regras de responsabilidade subjetiva e de responsabilidade objetiva. Também examinará as relações derivadas do sistema jurídico, interpretando e aplicando as normas de responsabilização à luz dos fundamentos teóricos disponibilizados pela teoria econômica (BATTESINI, 2011, p. 99).

\subsection{Regras de direito de propriedade e regras de responsabilidade civil}

Há duas importantes distinções na teoria econômica da responsabilidade civil. A primeira é a diferença existente entre as regras de direito de propriedade e as de responsabilidade civil ${ }^{27}$. De acordo com Posner e Landes, raramente, a propriedade e a responsabilidade civil são abordadas a partir de uma perspectiva unificada ${ }^{28}$ (LANDES; POSNER, 1987, p.30). Já a segunda diz respeito à diferença existente entre os dois regimes fundamentais da responsabilidade civil: o da responsabilidade objetiva e o da responsabilidade subjetiva.

De acordo com Posner e Landes, o direito de propriedade confere ao seu titular as prerrogativas exclusivas de usar, controlar e gozar de alguns recursos, ou seja, é o direito de excluir qualquer outra pessoa de se apoderar de um bem sem o consentimento de seu dono, independentemente de qualquer argumento (LANDES; POSNER, 1987, p. 29). Assim, se A tem o direito de propriedade sobre um carro, B não pode tomá-lo, com ou sem compensação,

\footnotetext{
${ }^{26}$ A teoria econômica também aponta outros objetivos da responsabilidade civil, como a redução dos custos dos acidentes, a dispersão social dos riscos, entre outros.

27 "O Estado tem a sua disposição duas maneiras básicas de proteger os direitos de propriedade. Por um lado, pode adotar regras de propriedade, sob as quais o direito de propriedade será protegido contra qualquer violação a partir da ameaça do uso de seu poder de polícia. Por outro lado, o Estado pode empregar regras de responsabilidade civil, sob as quais as violações são desencorajadas exigindo-se que os transgressores compensem as vítimas pelos eventuais danos que venham a sofrer" (KAPLOW; SHAVELL, 1996, p. 715).

${ }^{28}$ Embora, frequentemente, as regras de propriedade e de responsabilidade civil possam proteger o mesmo bem jurídico.
} 
convencendo o juiz de que o carro vale mais para ele (ou para a sociedade). Para tanto, B deverá persuadir A a vendê-lo, sob quaisquer termos que A estipule.

Contudo, fazem a ressalva de que o direito de propriedade nunca é tão absoluto como o exemplo possa sugerir. O direito de A sobre o carro pode ser absoluto contra tentativas privadas de usurpação, mas é relativo (qualifield) contra o governo, que pode tomá-lo diante da supremacia do interesse público, devendo apenas compensar A com valor compatível com o preço de mercado do carro. Apesar de tal consideração, os direitos de propriedade convencionais - a propriedade territorial, direitos de personalidade ${ }^{29}$, propriedade intelectual, entre outros - confere ao seu titular o poder de excluir outros de usar e gozar de tal propriedade.

A regra de responsabilidade, por sua vez, institui um direito não de excluir outro sujeito do uso de algum recurso, mas apenas de reivindicar compensação por eventuais prejuízos produzidos. Guido Calabresi e A. Douglas Melamed vão mais longe. Sustentam que "sempre que alguém puder destruir um direito inicial porque está disposto a pagar um valor objetivamente determinado por ele, esse direito é protegido por uma regra de responsabilidade civil” ${ }^{30}$ (CALABRESI; MELAMED, 1972, p. 1.092). Posner e Landes sustentam que:

\begin{abstract}
A maneira prática de distinguir o direito de propriedade de uma regra de responsabilidade é adotar como referência o remédio legal disponível para uma vítima real ou potencial de um dano. Aquele que possui o direito de impedir a conduta causadora do dano ou de obter punitive damages, tem uma regra de propriedade, porque a injunção ou a ameaça de punitive damages deve deter um potencial autor de dano de buscar se apropriar do direito sem negociar com o seu dono. Se, contudo, o titular conta somente com o direito de receber uma compensação, então está protegido apenas por uma regra de responsabilidade civil, pois qualquer um que estiver preparado para pagar o preço do prejuízo, não será dissuadido a não causá-lo (LANDES; POSNER, 1987, p. 30).
\end{abstract}

De acordo com as considerações de tais autores, sob a regra de responsabilidade civil, o potencial autor do dano pode causá-lo, desde que esteja disposto a pagar o seu preço: a indenização da vítima ${ }^{31}$.

Posner e Landes concluem que o sistema de direito de propriedade canaliza as transações para o mercado, na medida em que alguém, para se apoderar do direito de propriedade de seu titular original, deve negociá-lo. Em outras palavras, permite que cada parte diga quanto um direito vale para ela, conferindo ao seu detentor o veto se a oferta do interessado não for suficiente. O sistema da responsabilidade civil, por outro lado, permite

\footnotetext{
${ }^{29}$ Posner e Landes falam em "personal property” (1987, p. 30). Creio que deva corresponder aos direitos de personalidade, como o direito ao próprio corpo, à imagem, à integridade física e psíquica, à identidade, entre outros.

${ }^{30}$ Tradução livre do trecho: "Whenever someone may destroy the initial entitlement if he is willing to pay an objectively determined value for it, an entitlement is protected by a liability rule”. (CALABRESI; MELAMED, 1972, p. 1.092)

${ }^{31}$ De acordo com o critério de Kaldor-Hicks, desde que seus benefícios (ganhos) sejam superiores aos prejuízos da vítima, não é necessário que tenha que compensá-la efetivamente.
} 
que as transações sejam efetuadas pelo sistema legal, no sentido de que a violação de um direito é permitida com base no valor determinado pelo órgão do Estado ao invés de determinado pelas partes (LANDES; POSNER, 1987, p. 31).

Frequentemente, os custos para estabelecer o valor inicial de um direito, por meio de uma negociação, são tão elevados que, ainda que sua transferência venha a beneficiar todos os interessados, a transação não ocorrerá. Tal questão introduz um novo conceito na análise da distinção entre as regras de direito de propriedade e de responsabilidade: os custos de transação. Segundo Thráinn Eggertsson, custos de transação são "os custos que surgem quando os indivíduos comercializam direitos de propriedade sobre ativos econômicos e fazem valer seus direitos exclusivos" (EGGERTSSON apud BATTESINI, 2011, P. 47). De modo mais amplo, os custos de transação envolvem os custos com a obtenção de informação necessária (descobrir o titular do direito), com a negociação em si (custo de oportunidade, custo de consultores e advogados) e com a própria execução do acordo (custos de fiscalização, custos de recurso aos tribunais) (RODRIGUES, 2007, p. 50).

Como mencionado anteriormente, a aplicação mais famosa do conceito de custo de transação é o Teorema de Coase, o qual desempenha um papel fundamental na análise econômica da responsabilidade civil.

Ronald Coase propôs uma forma de estruturar o sistema jurídico de modo a proporcionar um aumento da eficiência alocativa. Para tanto, apresentou duas hipóteses de análise: a de ausência e a de presença de custos de transação. O referido autor sustenta que a eficiência com a qual os recursos serão empregados não é afetada pela atribuição inicial dos direitos, desde que os custos de transação sejam iguais a zero ${ }^{32}$. Em outros termos, em condições ideais de clara definição dos direitos de propriedade e de custos de transação nulos, as partes negociarão de forma a atingir uma solução eficiente, alocando os recursos em seus usos mais valiosos ${ }^{33}$.

\footnotetext{
${ }^{32}$ A atribuição inicial de direitos de propriedade pode não afetar a eficiência, tal como definida pela Análise Econômica do Dir eito, quando os custos de transação forem nulos, mas, certamente, terá efeitos sobre a riqueza, que pode afetar tantos os preços quanto a própria alocação de recursos. (LANDES; PONER, 1987, p. 35)

${ }^{33}$ Cooter e Ulen apresentam um exemplo simples da aplicação do teorema. Suponha que um pecuarista vive ao lado de um agricultor. Este cultiva milho apenas em uma parte de sua propriedade. O pecuarista, por sua vez, cria gado em toda a sua terra. A divisa entre a fazenda e a propriedade do agricultor é clara, mas não há cerca. De tempos em tempos, o gado invade a propriedade do agricultor e ocasiona danos à plantação. O prejuízo poderia ser reduzido se fosse construída uma cerca. Contudo, tal medida apresenta um custo. A lei pode atribuir o direito a um ou a outro: o direito do agricultor de ver a sua terra livre da invasão de gado ou o direito do pecuarista de manter o seu gado livre (ainda que na propriedade do agricultor). Se o regime adotado for o primeiro (direito do agricultor), o pecuarista deverá manter o seu gado longe da propriedade do agricultor, caso contrário, pagará por qualquer prejuízo provocado pela invasão não autorizada. Se o regime adotado for o segundo (direito do pecuarista), o agricultor deverá manter o gado fora de sua propriedade, sob pena de arcar com os prejuízos que vierem a ocorrer. Segundo Coase, o ideal seria uma regra jurídica que incentivasse a eficiência tanto na criação de gado quanto no cultivo de milho. De acordo com Cooter e Ulen, essa questão apresenta uma conclusão contraintuitiva, mas que pode ser explicada a partir de alguns números. Suponha que sem a cerca, a invasão do gado custe ao agricultor $\$ 100$ em danos. O custo de instalação de uma cerca ao redor do campo de cultivo de milho é de $\$ 50$ e o custo para cercar a fazenda do pecuarista é de $\$ 75$. Conclui-se que o dano de $\$ 100$ pode ser evitado a um custo de $\$ 50$ para o agricultor e de $\$ 75$ para o pecuarista. A eficiência exige que o agricultor construa a cerca para isolar o campo de cultivo. Sob a primeira regra jurídica (direito do agricultor), o pecuarista não arcará com o dano de $\$ 100$ a um custo de $\$ 75$, ou seja, economizará $\$ 25$. Sob a segunda regra (direito do pecuarista), o agricultor pode evitar o seu prejuízo de $\$ 100$ a um custo de $\$ 50$
} 
Essa conclusão também se aplica à escolha entre regras de direito de propriedade e de responsabilidade. Se não houver obstáculos para a consumação de acordos, não fará diferença qual o regime legal aplicado, ou seja, será irrelevante se a regra adotada é de responsabilidade civil ou de direito de propriedade. Mesmo que o regime escolhido não conduza a um resultado eficiente, as partes poderão, em princípio, negociar e incorporá-lo a um acordo ${ }^{34}$. Ainda que não seja alcançado, será possível uma diminuição dos custos totais e, assim, ambos os lados serão beneficiados.

Posner e Landes sustentam que o Teorema de Coase, implicitamente, evidencia a superioridade das regras de direito de propriedade em relação às regras de responsabilidade, sempre que os custos de transação são baixos (eles nunca serão iguais a zero no mundo real). Mais precisamente, sempre que os custos de transação forem mais baixos que os benefícios decorrentes do acordo. Concluem que:

Quando os custos das transações voluntárias no mercado são baixos, a abordagem do direito de propriedade é economicamente preferível em comparação à abordagem da responsabilidade, porque o mercado é um registro de valores mais confiável que o sistema legal. No entanto, quando os custos das transações voluntárias são altos, a abordagem do direito de propriedade será inferior porque irá impedir que os recursos sejam transferidos para os seus usos mais valiosos (LANDES; POSNER, 1987, p. $31)$.

Shavell e Kaplow acrescentam que a única conclusão que pode ser esboçada é a de que a escolha entre uma regra e outra, provavelmente, é menos importante quando as partes podem negociar do que quando não podem.

Cooter e Ulen destacam uma importante questão acerca da atribuição de direitos de propriedade: quando se tratar de atividades que, eventualmente, possam causar algum tipo de dano, o sistema legal (leis e juízes) precisará decidir se uma das partes tem o direito de causálo ou se a outra tem o direito de se ver livre dele. Acrescentam que, aparentemente, a justiça exige que a parte que causa o prejuízo pague por ele. A eficiência, por outro lado, exige que o direito seja alocado à parte que lhe atribui maior valor (COOTER; ULEN, 2010, p. 102).

\footnotetext{
(cercará a sua plantação). Aparentemente, a segunda regra, que economiza $\$ 50$, é mais eficiente que a primeira, que economiza apenas $\$ 25$. Contudo, Cooter e Ulen afirmam que essa eficiência é aparente. Suponha que o agricultor e o pecuarista tivessem criado uma sociedade e combinado os seus interesses empresariais. Neste caso, eles buscariam maximizar os seus lucros conjuntos; logo, construiriam uma cerca ao redor da plantação e não da fazenda, independentemente da atribuição inicial do direito, se ao pecuarista ou se ao agricultor. Suponha que não exista uma sociedade entre eles, mas que uma negociação entre ambos seja viável. Ainda que a regra aplicável seja a primeira (direito do agricultor), a cooperação conduz à construção da cerca ao redor da plantação, pois o pecuarista estará disposto a pagar qualquer valor entre \$50 e \$75 para que o agricultor construa a cerca, e este aceitará. (COOTER; ULEN, 2010, p. 100-102)

${ }^{34}$ Considere uma regra de propriedade em que a vítima tem direito a ficar livre de qualquer dano, mas a alocação de recursos não é eficiente porque o prejuízo é $\$ 1000$ e o custo de prevenção é $\$ 1200$. Se for viável um acordo que possibilite a manutenção da atividade do potencial autor, ele estará disposto a pagar uma soma entre $\$ 1000$ e $\$ 1200$ para mantê-la. Considere, agora, um prejuízo de $\$ 1500$ e um custo de prevenção de $\$ 1200$. No entanto, a indenização estipulada pela regra de responsabilidade subestima o prejuízo, fixando-o em $\$ 1000$. O autor optaria por causar o dano na ausência de negociação. Contudo, se as partes negociarem, a vítima faria uma oferta entre \$200 e \$500 para induzir o autor a não causar o dano. Esses exemplos demonstram que, sempre que a negociação for bem sucedida, o resultado alcançado será ótimo. Consequentemente, a escolha entre uma regra e outra não afeta a eficiência. (KAPLOW; SHAVELL, 1996, p.734)
} 
Essa discussão introduz outro conceito fundamental para a análise econômica da responsabilidade civil: o de externalidades. Segundo Vasco Rodrigues, externalidade é o impacto que a atividade de um agente econômico impõe a outro que não por via do sistema de preços $^{35}$. Será positiva ou negativa conforme o impacto se traduza em benefício ou em custo para quem a suporta. A teoria econômica da responsabilidade se ocupará, principalmente, com os efeitos das externalidades negativas.

Entende-se por externalidades negativas os "resultados adversos que ocorrem como subproduto da atividade desempenhada pelo potencial autor do dano, sendo um exemplo comum a poluição causada pelas indústrias" (KAPLOW; SHAVELL, 1996, p. 716). Steven Shavell e Louis Kaplow fazem uma comparação entre as regras de propriedade e as de responsabilidade como métodos de controle de externalidades negativas. Concluíram que a primeira é preferível à segunda.

Em sua análise, eles assumiram alguns pressupostos de simplificação: que só existe uma vítima e um autor em potencial; que o autor pode evitar o dano se arcar com o custo de prevenção (no caso da poluição, instalando filtros nas chaminés), entre outros. Como mencionado anteriormente, sob a regra de propriedade, dois fatores deverão ser considerados: a atribuição de um direito à vítima ou ao autor e a absoluta proteção desse direito ${ }^{36}$. Por outro lado, sob a regra de responsabilidade, o potencial autor pode, em princípio, causar o dano, mas terá que compensar a vítima pelo prejuízo.

As vítimas e os autores, normalmente, não negociam um com o outro porque os custos de transação são elevados, como nas hipóteses de poluição ou de acidente de trânsito ${ }^{37}$. Se as partes não negociam, a ocorrência de um dano será diretamente determinada pela regra jurídica aplicada. Sob uma regra de propriedade, haverá prejuízo se o ofensor é titular do direito de causá-lo, enquanto que, sob a regra de responsabilidade, haverá dano se ele escolher causá-lo e arcar com a indenização.

Se a informação do Estado acerca de um eventual dano e de seus respectivos custos de prevenção é perfeita, ambos os regimes são equivalentes, porque, sob qualquer um deles, o resultado eficiente será alcançado. Quando se tratar de uma regra de propriedade, o Estado

\footnotetext{
35 “Quando alguém fuma, a fumaça do cigarro implica em um custo para a saúde das pessoas que estão próximas (os fumantes passivos). Este custo é um exemplo de externalidade negativa. Contudo, se o fato dessa pessoa comprar cigarros contribui para o aumento do preço do tabaco e, dessa forma, prejudica, economicamente, o restante dos fumantes, esse prejuízo não é considerado uma externalidade, por ocorrer através do sistema de preços" (RODRIGUES, 2007, p. 41).

${ }^{36}$ De modo que, se a vítima tem o direito de ficar livre de qualquer dano, o potencial autor estará proibido de provocá-lo. Por exemplo, seria aplicada uma sanção tão severa que ele sequer se atreveria a causá-lo. Igualmente, se o autor é titular do direito de causar o dano, não há nada que a vítima possa fazer para impedi-lo. (KAPLOW; SHAVELL, 1996, p.723)

${ }^{37}$ Aqui não se trata da possibilidade de um acordo após o acidente, mas da viabilidade de se negociar um cuidado socialmente eficiente. Por exemplo, cada motorista não pode negociar com todos os demais para chegar a um acordo a respeito da forma como os cu stos dos acidentes futuros deverão ser alocados. Tampouco, pode firmar uma série de acordos privados (com os demais motoristas, com os ciclistas e com os pedestres) para garantir um cuidado socialmente eficiente.
} 
atribuirá o direito à vítima, se o prejuízo supera os custos com precaução, e ao ofensor, na hipótese contrária. Quando se tratar de uma regra de responsabilidade civil, o Estado estabelece que a indenização será equivalente ao prejuízo, assim o potencial autor somente causará o dano se os custos com a sua prevenção superarem aquele ${ }^{38}$.

Quando a informação do Estado é imperfeita, assume-se que não tem conhecimento sobre os custos de precaução, mas que pode determinar o prejuízo da vítima. Nesse caso, a regra de responsabilidade se mostra superior à regra de propriedade.

Sob este último regime, o Estado não saberá a quem atribuir o direito, uma vez que desconhece se os custos de precaução superam o prejuízo suportado pela vítima. Inevitavelmente, o Estado cometerá erros na atribuição de direitos quando não dispuser de informações suficientes ${ }^{39}$. Por outro lado, sob o regime da responsabilidade civil, o resultado sempre será eficiente, pois o autor somente causará o dano se os custos de prevenção superarem os benefícios em adotá-la ${ }^{40}$. Quanto a esse aspecto, Shavell e Kaplow identificam uma vantagem da regra de responsabilidade: o Estado poderá se aproveitar do conhecimento que o potencial autor do dano naturalmente dispõe sobre os seus gastos com prevenção (KAPLOW; SHAVELL, 1996, p. 725).

É provável, no entanto, que as dificuldades em delimitar o prejuízo favoreçam a proteção por regra de propriedade. Por exemplo, desconhecer os efeitos nocivos da poluição por exemplo, se pode causar apenas uma irritação nas vias respiratórias ou um câncer - faz com que as pessoas não queiram lidar com o risco de um dano considerável e, portanto, acabem concordando com o direito de propriedade da vítima, o direito a um ar limpo. Shavell e Kaplow sustentam que esse argumento desconsidera um importante ponto: que, sob uma regra de responsabilidade civil, tenderá a não haver tanta poluição se o risco de dano for alto, pois as indenizações também serão elevadas ${ }^{41}$.

$\mathrm{Na}$ verdade, em termos de proteção da vítima de um dano, uma regra de propriedade terá um resultado diferente daquele alcançado por uma regra de responsabilidade somente

\footnotetext{
${ }^{38}$ Presume-se que o potencial autor sempre conhece os seus custos de prevenção. Contudo, há hipóteses em que ele não terá conhecimento dos custos, principalmente, quando se tratar do desenvolvimento e do uso de novas tecnologias. Mesmo assim, as informações que detém, frequentemente, são melhores que as do Estado (KAPLOW; SHAVELL, 1996, p.725).

39 “Se o dano é $\$ 1000$, mas o Estado não sabe se os custos de prevenção são $\$ 800$ ou $\$ 1200$, cometerá um de dois erros: atribuirá à vítima o direito de se ver livre de qualquer prejuízo quando, de fato, o custo de prevenção é \$1200 (quando é socialmente desejável que o dano ocorra), ou atribuirá ao autor o direito de causar dano quando os custos de prevenção são apenas $\$ 800$ (quando seria socialmente desejável que ofensor se prevenisse)" (KAPLOW; SHAVELL, 1996, p. 725).

${ }^{40}$ Diante de um prejuízo de $\$ 1000$, o autor causará o dano se, e somente se, o seu custo com prevenção for $\$ 1200$; se o seu custo for apenas $\$ 800$, ele irá se precaver ao invés de causar o dano. Presume-se que o autor conhece os seus custos de precaução.

${ }^{41}$ Eles afirmam que sempre será possível proteger as vítimas, ainda que sob o regime da responsabilidade civil, fixando indenizações mais elevadas que o efetivo dano. Para alguns autores, esta proposição não se aplica ao direito brasileiro, tendo em vista que o dano é a medida da indenização (Art. 944 do CC/02 - "A indenização mede-se pela extensão do dano"), sob pena de enriquecimento sem causa da parte ressarcida. Há, contudo, autores e precedentes jurisprudenciais que vislumbram um caráter punitivo e preventivo das compensações por danos extrapatrimoniais, o que, para eles, autorizaria indenizações mais elevadas.
} 
quando os custos de precaução superarem o provável prejuízo (hipótese em que a prevenção do dano seria socialmente indesejável).

$\mathrm{O}$ argumento mais forte para a aplicação de regras de responsabilidade civil ao invés de direito de propriedade, quando se tratar de externalidades negativas, pode ser levantado quando a solução ótima para um problema de usos conflitantes requer, em certa medida, a restrição ao usufruto de um direito por parte do autor potencial de dano. Como salientado anteriormente, o regime de direito de propriedade pode se mostrar pouco eficiente se os custos de transação são proibitivos, pois, se o autor potencial de dano é titular do direito de propriedade (por exemplo, direito de poluir), muitos danos ocorrerão (LANDES; POSNER, 1987, p. 36).

Por fim, o comportamento da vítima pode ter implicações na escolha entre uma regra e outra. Quando as vítimas são compensadas por seus prejuízos, os incentivos para prevenir ou mitigar o dano são enfraquecidos. Nesse contexto, a regra de responsabilidade se torna menos atrativa. Contudo, há medidas que podem ser adotadas, como limitar as indenizações, adotar algumas defesas (culpa proporcional, contributiva e exclusiva da vítima), entre outras.

Por outro lado, os incentivos da vítima também serão diluídos caso a regra adotada seja a de propriedade. $\mathrm{Na}$ ausência de negociação, as vítimas não sofrem perdas, pois, sob o regime de regra de propriedade, o ofensor é proibido de causar qualquer dano (considerando os pressupostos assumidos na análise). Assim, as vítimas não fazem nada para reduzi-lo. Logo, é possível concluir que a conduta da vítima é igual sob ambas as regras.

Quando há negociação, a situação é mais complicada. Nesse caso, as regras de propriedade e responsabilidade geralmente não serão equivalentes no que diz respeito ao comportamento da vítima. Uma regra de propriedade que proteja o direito do ofensor de causar dano talvez seja atrativa, visto que a vítima terá fortes incentivos para evitar a exposição ao dano ou para reduzi-lo se já foi exposta a ele. Shavell e Kaplow falam em "talvez" porque o preço de um incremento nos incentivos da vítima é a diluição dos incentivos do autor (KAPLOW; SHAVELL, 1996, p. 738-739).

Tais considerações acerca do comportamento da vítima podem reduzir a atratividade da regra de responsabilidade, mas, tampouco, confere suporte às regras de propriedade. Ao invés disso, evidenciam a necessidade de novas formas de tutela de direitos ou de modificação das regras existentes. 


\subsection{Responsabilidade subjetiva e responsabilidade objetiva}

A teoria econômica também se ocupa com outra importante distinção: a existente entre a responsabilidade subjetiva e a objetiva. Sob a primeira regra, alguém será considerado responsável por um acidente que venha a causar se agiu com culpa (negligência, imprudência ou imperícia ${ }^{42}$ ), isto é, se adotou um nível de cuidado inferior ao denominado "devido cuidado" (due care). Sob a segunda regra, por outro lado, alguém será responsável por um prejuízo que venha a causar independentemente de culpa, desde que haja relação de causalidade entre a sua conduta e o dano.

A teoria jurídica da responsabilidade civil se articula em torno da noção de culpa. Eugênio Battesini ressalta que a maioria dos sistemas alçou a culpa à posição de princípio geral definidor da responsabilidade civil (BATTESINI, 2011, p. 204).

A ideia básica inerente à noção de culpa é a de erro de conduta, de falha na adoção de medidas apropriadas de precaução. Hans-Bernd Schäfer e Claus Ott destacam que a responsabilidade subjetiva se relaciona diretamente com a função de controle da conduta do indivíduo, uma vez que, “de acordo com o princípio da culpabilidade, será responsável pelo dano quem o houver causado por uma conduta deficiente, quer dizer, por um controle errôneo de sua própria conduta" (SCHÄFER e OTT apud BATTESINI, 2011, p. 205).

Carlos Roberto Gonçalves sustenta que, em qualquer de suas modalidades, a culpa implica a violação de um dever de diligência, ou seja, a violação do dever de previsão de certos atos ilícitos ${ }^{43}$ e de adoção das medidas capazes de evitá-lo. A responsabilidade subjetiva se refere, tanto do ponto de vista econômico quanto jurídico, ao controle do nível de diligência. Entretanto, a grande dificuldade da teoria da culpa está justamente em determinar o nível desse dever de cuidado.

No plano metodológico, a comparação entre o comportamento concreto e o abstrato demanda a fixação de critérios objetivos para a definição da licitude ou não da conduta. Nesse sentido, a teoria jurídica, tradicionalmente, recorre a noções como o nível de cuidado adotado pelo homem prudente, o comportamento do homem médio (do bonus pater familiae, ou, até mesmo, do homo economicus) na mesma situação, entre outras.

\footnotetext{
${ }^{42}$ De acordo com Carlos Roberto Gonçalves, "imprudência é a precipitação ou o ato de proceder sem cautela. Negligência é a inobservância de normas que nos ordenam agir com atenção, capacidade, solicitude e discernimento. E imperícia é a falta de habilidade ou inaptidão para praticar certo ato". (GONÇALVES, 2011, p. 317)

${ }^{43} \mathrm{O}$ autor sustenta que a correta conceituação de culpa não pode prescindir do elemento "previsibilidade". "Só se pode, com efeito, cogitar de culpa quando o evento é previsível. Se, ao contrário, é imprevisível, não há cogitar de culpa [sic]” (GONÇALVES, 2011, p. 317). Não há previsão na culpa, mas há previsibilidade. Culpa é a não previsão de algo previsível. Alguns autores propõem que a responsabilidade subjetiva seja definida como "a responsabilidade por danos razoavelmente previsíveis e evitáveis" e que a responsabilidade objetiva, por conseguinte, seja definida como a responsabilidade por danos "imprevisíveis e/ou inevitáveis" ou que "apenas possam ser prevenidos a custos excessivos" (BATTESINI, 2011, p. 228)
} 
Sob a perspectiva econômica, os juízes ${ }^{44}$ devem, inicialmente, buscar identificar o nível eficiente de precaução, para, em seguida, verificar a existência ou não de culpa. $\mathrm{Na}$ decisão do caso United States vs. Carroll Towing Company, o Juiz Learned Hand descreveu o dever de cuidado como uma função de três variáveis: (1) a probabilidade de ocorrência do dano ( $P$ - probability); (2) a gravidade do dano se o acidente vier a ocorrer $(L-$ losses $)$; e (3) o custo da precaução adequada ( $B$ - burden) (CALABRESI; HIRSCHOFF, 1972, p. 1.05657). Ele enunciou que a responsabilidade depende de que $B$ seja menor do que $L$ multiplicado por $P(B<P . L)$, ou seja, se o custo de prevenção for inferior ao custo esperado do acidente (produto entre o valor do dano efetivo e a respectiva probabilidade de sua ocorrência), a falha do agente pode ser considerada negligência (culpa para fins de responsabilização).

Robert Cooter e Thomas Ulen salientam que a formulação de Hand não deixa claro se as variáveis se referem a valores marginais ou a valores totais. Eugênio Battesini destaca que, sob a ótica econômica, a determinação do nível ótimo de precaução é elucidada de maneira mais satisfatória quando, ao invés de valores totais, são consideradas as variações incrementais das variáveis (BATTESINI, 2011, p. 128). Assim, os custos sociais dos acidentes (a soma dos custos de precaução e dos danos esperados) são minimizados quando os custos marginais (associados ao nível de precaução adotado pelo autor) se igualam aos benefícios marginais (associados à redução do dano esperado) ${ }^{45}$. Em outras palavras:

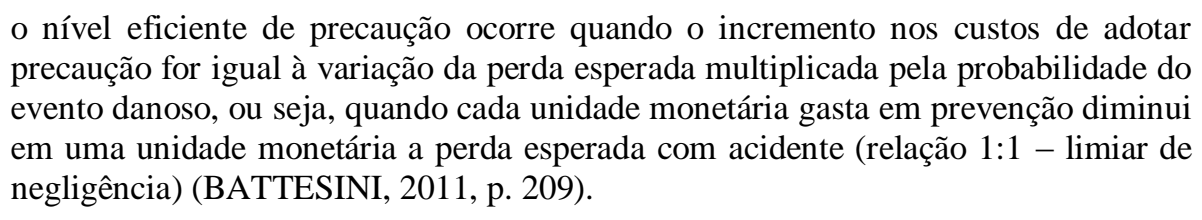

Diante de tais considerações, a fórmula de Hand enuncia que o autor do dano será considerado culpado se o custo marginal de sua prevenção for menor do que o benefício marginal resultante, ou seja, será responsável sempre que a precaução adicional se justificar em termos de custos.

Hans-Bernd Schäfer e Claus Ott apontam que o mérito da formulação da regra de Hand consiste em tornar explícita a existência de "uma particular quantidade de precaução que é economicamente razoável e é dependente da probabilidade ou do risco do dano" (SCHÄFER e OTT apud BATTESINI, 2011, p. 208). Richard Posner sustenta que, se essa fórmula algébrica, de fato, considera valores marginais, isso dará uma vantagem aos tribunais,

\footnotetext{
${ }^{44} \mathrm{Na}$ verdade, essa verificação não ocorre apenas no âmbito jurídico. O Poder Legislativo e as autoridades reguladoras também têm interesse em identificar o nível de precaução adequado, a fim de fixar parâmetros em leis e regulamentações.

${ }^{45}$ Quando os custos marginais do acidente se igualarem aos benefícios marginais, estar-se-á diante do nível ótimo de precaução (ponto em que os custos sociais serão minimizados de forma eficiente).
} 
uma vez que, usualmente, é complicado obter outras informações além de pequenas variações no nível de precaução adotado pelo potencial autor (POSNER, 2003, p. 168) ${ }^{46}$. Eugênio Battesini afirma que tal consideração evidencia dois pontos importantes: a obtenção das informações necessárias para a aplicação da fórmula de Hand e a atuação do Judiciário na determinação de parâmetros de cuidado apropriados.

A aplicação de uma regra de responsabilidade subjetiva, de acordo com Eugênio Battesini, requer que os juízes sejam capazes de tomar dois tipos de decisão: primeiro, devem estabelecer o parâmetro de diligência aplicável ao caso (qual o comportamento razoável em abstrato), e segundo, devem compará-lo à conduta efetivamente adotada (BATTESINI, 2011, p. 211). Sob a perspectiva econômica, a primeira decisão envolve a determinação de um nível razoável de precaução exigível para o caso concreto (algo equivalente ou aproximado ao nível ótimo), enquanto a segunda envolve uma confrontação entre o nível razoável estabelecido e o nível efetivamente adotado. Na prática jurídica, esse processo costuma ser mais simples:

com frequiência nós não observamos um processo em dois estágios no qual um
standard é estabelecido e então o comportamento é confrontado, mas, ao invés, um
processo de decisão em um estágio, [...] o litígio judicial envolve o exame de
alternativas concretas para evitar um particular acidente, sendo que em muitos casos
é suficiente que a corte possa determinar com certeza que era requerido que o réu
fizesse mais do que ele fez, ou que reste claro que o réu tenha tomado mais do que a
precaução suficiente (BATTESINI, 2011, p. 211).

$\mathrm{Na}$ verdade, a fórmula de Hand evidencia que, para a aferição de culpa, e consequente aplicação de uma regra de responsabilidade subjetiva, é relevante ponderar os custos e os benefícios de se evitar um dano. Contudo, tal análise exige a obtenção de uma grande quantidade de informações (seja por parte do autor, da vítima, do juiz, do legislador ou do órgão regulador), bem como a consideração de quem está em melhor posição para obtê-las.

A responsabilidade objetiva, por outro lado, prescinde de culpa, satisfazendo-se com a constatação do dano e do nexo de causalidade. Para Posner, a responsabilidade objetiva significa que alguém que cause um acidente será responsável pelo prejuízo da vítima ainda que não o pudesse ter evitado por meio do exercício do devido cuidado (POSNER, 2003, p. 177). No entanto, Guido Calabresi e Jon Hirschoff ressaltam que isso não quer dizer que a parte objetivamente responsável é uma seguradora universal da vítima não importa as circunstâncias em que o dano venha a ocorrer (CALABRESI; HIRSCHOFF, 1972, p.1.056).

Em muitos ordenamentos, a responsabilidade subjetiva convive com a objetiva (sistema dualista). Aquela subsiste como regra geral a presidir a responsabilidade civil, mas

\footnotetext{
${ }^{46}$ Ele ainda acrescenta que o problema central é encontrar o nível ótimo de precaução, isto é, o nível que minimizará os custos sociais dos acidentes (custos esperados do dano mais os custos de prevenção - P. $L+B$ ).
} 
tem se mostrado insuficiente em muitos aspectos. Esta, por sua vez, tem conquistado cada vez mais espaço. Contudo, mesmo tendo sido objeto de discussão por muitos anos, ainda há muita incerteza quanto ao seu significado e seus limites (BATTESINI, 2011, p. 228).

Ao contrário da responsabilidade subjetiva, que se respalda no sentimento de que o autor de um dano deve responder por sua ação ou omissão culposa, a responsabilidade objetiva apresenta diversos fundamentos que justificam o nexo imputação. Dentre eles, a teoria jurídica aponta os imperativos de política social (segurança e paz); o princípio de equidade; o abuso de direito; a teoria da garantia, baseada no dever de segurança impostos a determinadas pessoas (os pais em relação aos atos de seus filhos ou os empregadores pelos atos de seus empregados); e, sobretudo, a teoria do risco ${ }^{47}$.

De acordo com esta última, "a obrigação de reparar um dano surge do simples exercício da atividade que o agente desenvolve em seu interesse e sob seu controle, em função do perigo que dela decorre para terceiros" (GONÇALVES, 2011, p. 486). Tem-se, então, o risco como fundamento da responsabilidade.

Pietro Trimarchi, em citação realizada por Eugênio Battesini, faz uma interessante análise acerca da responsabilização objetiva pelo risco do empreendimento. Para ele, o risco introduzido na sociedade pela atividade empresarial é parte da responsabilidade do empreendedor e, como tal, deve ser suportado como parcela integrante de seus custos de produção, uma vez que os custos sociais de eventuais acidentes podem ser traduzidos em gastos economicamente administráveis e conhecidos. Caso contrário, tais custos serão transferidos a terceiros, o que conduz a resultados socialmente indesejáveis (BATTESINI, 2011, p. 56).

A aplicação da responsabilidade objetiva deve considerar alguns fatores, dentre eles, Posner e Landes apontam: elevados danos esperados com o acidente; a impossibilidade de evitá-los mediante o exercício de elevada precaução e a viabilidade de reduzi-los pela restrição ou realocação da atividade. $\mathrm{O}$ primeiro fator, quando presente, evidencia substanciais benefícios sociais associados à redução do nível de acidentes. O segundo, por sua vez, demonstra que tal diminuição não pode ser, economicamente, alcançada apenas conduzindo a atividade com maior precaução. Por fim, o terceiro fator indica que a redução das taxas de acidente talvez possa ser, economicamente, alcançada com a redução ou a

\footnotetext{
${ }^{47}$ A teoria do risco comporta diversas modalidades, dentre elas, a do risco integral (que admite o dever de indenizar até mesmo nas hipóteses em que não há a caracterização do nexo causal); a do risco criado (que atribui responsabilidade ao agente que desenvolve atividade potencialmente danosa); a do risco proveito (que atribui responsabilidade ao agente que tira proveito da atividade danosa, que usufrui de vantagens, não necessariamente econômicas), entre outras.
} 
eliminação da atividade, uma vez que não implicará grandes perdas sociais ${ }^{48}$ (LANDES; POSNER, 1987, p. 112).

A doutrina destaca que a responsabilidade objetiva também deverá ser empregada quando o controle do nível de atividade do potencial autor for o principal método de prevenção de acidentes; quando houver uma distribuição assimétrica de informações acerca do risco; quando se tratar de atividades novas (em que há pouca experiência no que diz respeito à segurança) ou de atividade perigosa "insubstituíveis"49, bem como em outros contextos.

A responsabilização objetiva tem conquistado espaço no campo da responsabilidade por fato do produto. Trata-se, contudo, de questão controvertida. Richard Posner sustenta que tal responsabilidade também pode ser explicada a partir da noção de negligência, mediante a aplicação da fórmula de Hand (análise dos custos e dos benefícios com a precaução). No entanto, a responsabilidade objetiva se justifica diante da assimetria de informações entre fabricante e o consumidor (BATTESINI, 2011, p. 234).

Todas essas considerações evidenciam uma importante questão: quais são os limites para a aplicação da responsabilidade objetiva? Apesar de reconhecerem que essa regra deve ser empregada com certos limites, raramente os juízes e o legislador estão seguros em tentar descrevê-los. Guido Calabresi e Jon Hirschoff ressaltam que os esforços, muitas vezes, conduzem a tentativas de equilibrar os custos do acidente e os custos em evitá-lo. Esta abordagem se assemelha a proposta expressa na fórmula de Hand (CALABRESI; HIRSCHOFF, 1972, p. 1.056).

A proposição de Hand parece cumprir a sua missão na teoria, porque, se aplicada corretamente, faria com que o autor arcasse com os custos do acidente sempre que os gastos para evitá-lo fossem menores. Nesse sentido, "todos os acidentes que valessem a pena evitar seriam evitados" (CALABRESI; HIRSCHOFF, 1972, p. 1.058). Ao mesmo tempo, todos os custos com danos decorrentes de acidentes que não valessem a pena ser evitados recairiam sobre as vítimas, o que ensejaria uma discussão sobre justiça.

Diante dessa questão sobre ponderar custos e benefícios, Calabresi e Hirschoff sugerem o "teste da responsabilidade objetiva". Este requererá apenas uma decisão acerca de qual das partes está em melhor posição para fazer a análise custo-benefício (ponderar os custos do acidente e os gastos em evitá-lo) e para agir nesse sentido ${ }^{50}$.

\footnotetext{
${ }^{48} \mathrm{Na}$ verdade, são fatores que evidenciam se uma atividade deve ou não ser considerada perigosa.

${ }^{49}$ Posner fala em atividades sem "bons substitutos" (POSNER, 2003, p.180).

${ }^{50}$ De acordo com Calabresi e Hirschoff, a pergunta dos juízes se reduziria a questionar quem pode evitar o acidente a um menor custo (the cheapest cost avoider). (CALABRESI; HIRSCHOFF, 1972, p. 1.060)
} 
De acordo com os referidos autores, o "teste da responsabilidade objetiva", aparentemente, parece ser de fácil aplicação. Ao invés de demandar um juízo sobre se o agente deveria ter evitado o dano porque os custos de precaução eram menores que os prováveis prejuízos com o acidente (proposição de Hand), o teste proposto simplesmente demandaria uma decisão quanto a se o autor ou a vítima estava em melhor posição para julgar se os custos de prevenção superavam os custos esperados com o acidente e, então, agir nesse sentido ${ }^{51}$.

Calabresi e Hirschoff sustentam que esse juízo, certamente, não é o mais simples. No entanto, sugerem que, na prática, é geralmente mais fácil de ser realizado corretamente do que o juízo proposto pelo teste de Hand.

Conclui-se que ponderar as circunstâncias da situação de risco, de um lado, e os esforços necessários para sua eliminação, de outro, constitui um importante aspecto da teoria econômica da responsabilidade civil. Para compreender como essas duas regras atuam na redução do número de acidentes, qual oferece maior proteção ou melhores incentivos para que as partes adotem comportamentos eficientes, a abordagem econômica da responsabilidade civil construirá diversos modelos.

\footnotetext{
${ }^{51}$ A questão não é mais "se" a prevenção vale a pena, mas qual da partes tem maiores condições de descobrir se a prevenção vale a pena. (CALABRESI; HIRSCHOFF, 1972, p. 1.060)
} 


\section{Modelos econômicos de análise da responsabilidade civil}

Os modelos teóricos básicos da análise econômica normativa da responsabilidade civil buscam identificar os incentivos que diferentes regras de responsabilização criam sobre as partes envolvidas em atividades com risco de acidentes, em especial, os proporcionados pelas regras de responsabilidade subjetiva e objetiva.

Verifica-se que, se potenciais autores de danos não são responsáveis, não contam com incentivos para adotar medidas de prevenção, uma vez que os custos da vítima representam para eles simplesmente uma externalidade. Por outro lado, se as vítimas esperam ser compensadas plenamente, tampouco terão incentivos para tomar precaução. Esse risco moral evidenciado de ambos os lados é um dos principais problemas enfrentados pela responsabilidade civil extracontratual, e os modelos econômicos tem por objetivo demonstrar como as regras de responsabilização e outros sistemas de controle podem contribuir para solucioná-lo.

Diversos autores, considerando o contexto do Common Law, propõem a análise dos efeitos dos regimes de ausência de responsabilidade, responsabilidade subjetiva e responsabilidade objetiva $^{52}$, bem como a combinação de tais regras com as diversas modalidades de defesa previstas: a negligência contributiva da vítima (contributory negligence), que enseja a perda do direito à indenização quando ela concorre culposamente para o evento; e a negligência relativa da vítima (comparative negligence), que não autoriza a perda do direito à indenização, mas somente a redução de seu valor, proporcionalmente a sua participação no evento danoso ${ }^{53}$.

O modelo básico de acidentes considerado pela teoria econômica da responsabilidade extracontratual envolve duas partes, o autor e a vítima. A partir disso, consideram-se duas modalidades de acidentes. Quando apenas uma das partes (geralmente, o autor) pode influenciar a probabilidade e a severidade dos danos, estar-se-á diante de um acidente unilateral, como os desastres aéreos. Quando, por outro lado, as condutas do potencial autor e

\footnotetext{
${ }^{52}$ Considerando o sistema brasileiro de responsabilidade civil, os modelos teóricos de análise econômica normativa podem ser aplicados às regras de: 1. ausência de responsabilidade, considerada para fins didáticos; 2 . responsabilidade subjetiva; 3 . responsabilidade objetiva; 4 . responsabilidade subjetiva com redução do valor da indenização proporcional à culpa da vítima; 5 . responsabilidade objetiva com redução do valor da indenização proporcional à culpa da vítima; 6. responsabilidade subjetiva com exclusão do nexo causal por culpa da vítima; e 7. responsabilidade objetiva com exclusão do nexo causal por culpa da vítima (BATTESINI, 2011, p. 124).

${ }^{53}$ Fábio Ulhoa Coelho sustenta que o direito da responsabilidade civil trata a concorrência da culpa da vítima de duas formas: como excludente de responsabilidade ou como fator de redução da indenização. Assevera que, no ordenamento brasileiro, a culpa concorrente da vítima não tem influência sobre a existência da obrigação, mas dá lugar à redução proporcional da indenização (COELHO, 2010, p.416-417). No sistema de responsabilidade civil brasileiro, afirma Eugênio Battesini, mesmo que a culpa da vítima não constitua fator excludente da responsabilidade (contributory negligence), afastando o nexo de imputação, ela é considerada para fins de exclusão do nexo de causalidade, na hipótese de culpa exclusiva da vítima, inclusive, quando se tratar de responsabilidade objetiva (BATTESINI, 2011, p. 123). O enunciado $\mathrm{n}^{\circ} 380$ da IV Jornada de Direito Civil do Conselho da Justiça Federal passou a prever a aplicação do parágrafo único do art. 944 do Código Civil de 2002, que trata da possibilidade de redução do montante indenizatório em face do grau de culpa do agente, às hipóteses de responsabilidade objetiva.
} 
da vítima podem influir no resultado danoso, estar-se-á, então, diante de um acidente bilateral, como as colisões entre motoristas e pedestres ${ }^{54}$.

Em termos gerais, os modelos teóricos permitem a análise dos incentivos proporcionados pelas regras de responsabilização sobre as partes envolvidas em atividades perigosas considerando cinco dimensões: o nível de precaução; o nível de atividade; o nível de informação; a distribuição dos riscos e os custos administrativos (BATTESINI, 2011, p. 124). É importante ressaltar que tais modelos são construídos a partir da adoção de um conjunto de hipóteses simplificadoras da realidade:

adotam como pressupostos que os agentes envolvidos em atividades com risco de acidentes, autor e vítima: são perfeitamente informados acerca da probabilidade e da severidade dos danos associados aos diversos níveis de precaução e de atividades passíveis de adoção; são neutros em relação ao risco; não consideram a influência dos custos administrativos em suas decisões; tomam decisões com vistas a maximizar sua utilidade esperada; enfrentam custos de transação elevados ${ }^{55}$, que impedem a prévia negociação dos danos decorrentes da atividade de risco; e não são influenciados por outras políticas sociais desenhadas para reduzir os custos dos acidentes. (BATTESINI, 2011, p.125)

A análise também assume que a redução dos custos sociais dos acidentes e a maximização do benefício social gerado pelo desenvolvimento das atividades de risco podem ser alcançadas por meio da formulação adequada de regras de responsabilidade civil.

\subsection{Acidentes unilaterais}

Em acidentes unilaterais, a conduta do autor é ativa, pois a adoção de medidas de prevenção de sua parte é determinante para a redução do risco de dano. O comportamento adotado pela vítima, por sua vez, não terá um peso significativo nesse sentido ${ }^{56}$.

De acordo com Robert Cooter e Thomas Ulen, o modelo econômico da responsabilidade civil tem por base dois elementos: o custo de precaução e o custo do prejuízo ou dano esperado (COOTER; ULEN, 2010, p. 332). Tal modelo considera que a

\footnotetext{
${ }^{54}$ É importante destacar que os modelos assumem que os acidentes podem ser determinados de forma probabilística, bem como que autor e vítima sabem, previamente, que ocuparão essas posições. Contudo, geralmente, as partes não sabem com antecedência se serão vítima ou autor.

${ }^{55}$ Como mencionado, em contexto de acidentes, os custos de transação se mostram bastante elevados, o que inviabiliza a negociação prévia (como a que determina a adoção de um nível eficiente de precaução) em muitos casos. Por exemplo, o condutor de um veículo teria que negociar a preferência nos cruzamentos com todos os outros motoristas, com os pedestres e com os ciclistas que pudesse vir a encontrar em seu trajeto. Ou mesmo, um fabricante teria que negociar as condições de garantia de seus produtos com todos os potenciais consumidores (BATTESINI, 2011, p.101).

${ }^{56}$ Steven Shavell destaca que, na primeira versão do modelo de acidentes, "será suposto que os acidentes são unilaterais por natureza: somente a adoção de medidas de cuidado por parte do potencial autor afeta o risco de acidentes; o comportamento da vítima não. Quando um avião colide com um prédio, por exemplo, ou quando a ruptura de um reservatório de água causa uma inundação, as vítimas, provavelmente, não poderiam ter feito muita coisa para prevenir o dano. Nesses casos, os acidentes podem ser encarados como quase literalmente unilaterais" (SHAVELL, 2003, Capítulo 2 - p.2).
} 
probabilidade de acidente diminui com o aumento da precaução. Contudo, adotar medidas de cuidado implica gastos ${ }^{57}$, de modo que, quanto maior o nível de cuidado adotado pelo autor, maiores serão os custos envolvidos.

Considere que o objetivo social seja a minimização da soma desses custos (custos sociais totais). Assim, antes de verificar como cada parte atuará diante de diferentes regras de responsabilidade, é importante determinar qual o nível de cuidado irá reduzi-los ${ }^{58}$.

Suponha que o acidente cause um prejuízo estimado em $\$ 100$ e ocorre com a probabilidade descrita na tabela1:

\begin{tabular}{|c|c|c|c|c|}
\hline $\begin{array}{c}\text { Nível de } \\
\text { Cuidado }\end{array}$ & $\begin{array}{c}\text { Custo de } \\
\text { prevenção }\end{array}$ & $\begin{array}{c}\text { Probabilidade de } \\
\text { dano }\end{array}$ & $\begin{array}{c}\text { Custos } \\
\text { esperados com o } \\
\text { dano }\end{array}$ & $\begin{array}{c}\text { Custos Sociais } \\
\text { totais }\end{array}$ \\
\hline Nenhum & $\$ 0$ & $15 \%$ & 15 & 15 \\
\hline Moderado & $\$ 3$ & $10 \%$ & 10 & 13 \\
\hline Elevado & $\$ 6$ & $8 \%$ & 8 & 14 \\
\hline
\end{tabular}

Fonte: SHAVELL, Steven. Analysis of Accident Law. Foundation of Economic Analysis of Law. Capítulo 2 p.2.

Nota-se que aumentar o nível de cuidado de nenhum para moderado reduz os custos esperados com danos em $5(15-10=5)$, mas envolve um custo de $\$ 3$. Por outro lado, adotar um nível de cuidado elevado reduziria os custos esperados com acidentes em apenas $2(10-8=2)$ e também envolveria um custo adicional de \$3. Assim, é possível concluir que adotar o nível moderado reduziria os custos sociais totais (13), enquanto que adotar um nível elevado não valeria à pena em termos de custos. Esse exemplo ilustra que o nível ótimo de cuidado pode não resultar do menor valor possível dos custos esperados com acidentes (SHAVELL, 2003, Capítulo $2-$ p.2).

Como mencionado anteriormente, sob a ótica econômica, a determinação do nível ótimo de precaução pode ser esclarecida de maneira mais satisfatória quando, ao invés de valores totais, são consideradas as variações incrementais das variáveis. Assim, os custos sociais dos acidentes são minimizados quando os custos marginais, associados ao nível de

\footnotetext{
${ }_{58}^{57}$ Implicam também outros custos, como perda de tempo e conveniência.

${ }^{58}$ Considere $\mathrm{x}$ como sendo o nível de cuidado a ser adotado, p como a probabilidade de acidente. Suponha que a probabilidade de acidente diminui com o aumento de precaução; logo, p é uma função decrescente de $x[p=p(x)]$. Além disso, todo acidente implica custos. D traduz o valor monetário do prejuízo que resulta de um acidente, de modo que D multiplicado por p equivale ao prejuízo esperado ("esperado" por causa do elemento probabilístico). Como p(x), o prejuízo esperado p(x).D é uma função decrescente de x, ou seja, quanto maior o cuidado menor será a prejuízo esperado. Para manter a análise simples, suponha que o valor da precaução c seja constante e não varia com a quantidade de $\mathrm{x}$, de modo que, c.x equivale à quantidade total gasta com a precaução. $\mathrm{O}$ x socialmente ótimo minimiza os custos sociais totais, c. $\mathrm{x}+\mathrm{p}(\mathrm{x})$. D, e pode ser descrito como $\mathrm{x} *$ (BATTESINI, 2011; COOTER e ULEN, 2010; SHAVELL, 2003).
} 
precaução adotado pelo autor, igualam-se aos benefícios marginais, associados à redução do dano esperado 59 . "Dito de outra forma, o nível ótimo de precaução ocorre quando, em termos incrementais, cada unidade monetária gasta em prevenção diminui em uma unidade monetária a perda esperada (relação 1:1)" (BATTESINI, 2011, p. 128).

Feitas tais considerações acerca do modelo formal que considera o nível de prevenção e caracterizada a existência de um nível ótimo de precaução, passa-se a analisar os incentivos necessários para atingi-lo (alocar os custos dos acidentes de forma eficiente) em contexto de acidentes unilaterais.

Em geral, ressalta Cooter e Ulen, os incentivos são eficientes quando quem toma a decisão acerca do nível de precaução a ser adotado internaliza os custos e os benefícios marginais de sua ação (COOTER; ULEN, 2010, p. 334). Na medida em que as regras de responsabilidade civil especificam como os danos dos acidentes são alocados, "o problema que se coloca é como o sistema jurídico pode induzir o autor a adotar a precaução em nível ótimo" (BATTESINI, 2011, p. 129).

É importante analisar quais são os efeitos das regras de responsabilização sobre a conduta do autor. Para tanto, serão considerados os incentivos gerados pelas regras de ausência de responsabilidade, responsabilidade subjetiva e responsabilidade objetiva.

Sob a regra de ausência de responsabilidade, a reparação dos danos decorrentes de acidentes não constitui encargo do autor, de modo que somente lhe interessam os custos de precaução. Por isso, a fim de maximizar o seu interesse privado, ele optará por não adotar qualquer medida de prevenção, uma vez que implicaria custos sem lhe trazer nenhum benefício. Portanto, tal regra induz o autor a se sentir "indiferente diante da ocorrência ou não de acidentes, ao desenvolver atividade de risco, optando por alternativa que minimize seus custos privados, relacionados tão somente com a prevenção" (BATTESINI, 2011, p. 130)

Verifica-se que, em contexto de ausência de responsabilidade, o autor não tem incentivos para adotar o nível ótimo de precaução, de modo que os custos do acidente (associados aos gastos com a adoção de medidas de cuidado) não são internalizados por ele. Diante disso, a vítima suportará os danos esperados, logo, terá incentivos para minimizar os custos com quais arcará, optando por adotar medidas de prevenção.

Conclui-se, então, que a regra de ausência de responsabilidade não constitui mecanismo eficiente de prevenção de acidentes unilaterais, uma vez que não proporciona

\footnotetext{
${ }^{59} \mathrm{O}$ custo de um pouco mais de precaução (custo marginal) equivale ao preço por unidade c. Um pouco mais de precaução reduz o cu sto esperado do prejuízo. Esta redução no custo esperado do prejuízo equivale à redução na probabilidade de um acidente, denominado -p' (x), multiplicado pelo custo do prejuízo D. Quando a precaução é eficiente, um custo de um pouco mais de precaução (custo marginal) equivale à resultante redução no custo esperado do prejuízo (benefício marginal). Assim, o nível eficiente de precaução $\mathrm{X}^{*}$ pode ser encontrado resolvendo-se a seguinte equação: c [custo marginal] = -p' $\left(x^{*}\right)$.D [benefício marginal]. (COOTER; ULEN, 2010, p.333)
} 
incentivos para que o autor adote precaução em nível ótimo. Contudo, como o custo total com que arcará a vítima equivale aos gastos com prevenção mais o prejuízo esperado, ou seja, a vítima internaliza os custos e os benefícios marginais da precaução, o regime de ausência de responsabilização lhe proporciona incentivos para adotar medidas de precaução eficientes.

Já sob o regime de responsabilidade objetiva, a reparação dos danos decorrentes de acidentes constituirá ônus do autor. Em tal situação, visto que arcará com a integridade dos custos relativos ao evento danoso, optará pela alternativa que irá minimizá-los, ou seja, irá se prevenir (BATTESINI, 2011, p. 131). Portanto, a regra de responsabilização objetiva cria incentivos para que o autor adote o nível ótimo de precaução, fazendo com que o seu objetivo coincida com o objetivo social de minimizar as perdas com acidentes.

Diante de uma regra de responsabilidade subjetiva, o autor do acidente será responsável pela reparação dos danos caso tenha agido sem observar o padrão mínimo de precaução exigível, de modo que, quando não caracterizada a sua culpa, os prejuízos serão suportados pela vítima ${ }^{60}$.

Se o sistema jurídico estabelecer que o padrão mínimo de precaução exigível equivale ao nível ótimo, o autor será conduzido a adotá-lo. Considere, como no exemplo ilustrado na tabela anterior, que o nível socialmente ótimo seja o nível moderado. Assim, caso o autor não adote nenhuma medida de cuidado, ele arcará com os danos esperados, enquanto que, se adotar o nível moderado ou elevado, não será responsabilizado. Como na regra de responsabilidade objetiva, o autor optará pela alternativa que minimize os custos de prevenção e os danos esperados (custos sociais totais), logo, optará pelo nível moderado:

[...] há duas razões para que os potenciais autores sejam conduzidos a adotar o devido cuidado se este for estabelecido pelos tribunais como igual ao nível ótimo ${ }^{61}$. Primeiro, os autores, claramente, não adotariam mais do que o devido cuidado, visto que escapariam da responsabilidade apenas adotando-o. Tomar mais precaução [adotar o nível elevado], portanto, não lhes trariam nenhuma vantagem e ainda envolveria custos adicionais. Segundo, os potenciais autores não desejariam adotar menos do que o devido cuidado se já fora fixado como equivalente ao nível socialmente ótimo. Se eles adotarem menos precauções do que o exigido, ficarão expostos ao risco de serem considerados responsáveis, hipótese em que seus custos esperados equivalerão aos custos totais com o acidente. Assim, eles optariam por

\footnotetext{
${ }^{60}$ Steven Shavell cita interessante reflexão acerca da regra de negligência: "[...] one may view the negligence rule as a hybrid of property rule granting a partial entitlement to cause harm and a liability rule (strict liability): provided that an injurer exercises due care, he effectively acquires a property rule entitlement to cause harm; only if he fails to take due care does he become liable for harm". Ele sustenta que essa característica da responsabilidade subjetiva - não há responsabilização se o devido cuidado for adotado - fornece aos potenciais autores um incentivo para exercitar o devido cuidado. Contudo, como todo regime de propriedade, apresenta o seguinte problema: quando a regra atribui direito, falha ao refletir o verdadeiro risco e custos de prevenção, um resultado desagradável. Além disso, o aspecto de regra de propriedade da responsabilidade subjetiva é incompleto quanto ao tipo de comportamento que busca controlar: autores não têm incentivos para reduzir a probabilidade de dano diminuindo o seu nível de atividade ou adotando outras medidas não previstas no padrão de cuidado estipulado (KAPLOW; SHAVELL, 1996, p.754).

${ }^{61}$ Assume-se que os tribunais, as leis e as regulamentações, podem determinar, com completa precisão, o nível de cuidado que deve ser adotado pelas partes. Caso contrário, seria mais prudente da parte adotar um nível mais elevado de precaução para não correr o risco de ser considerada responsável injustamente.
} 
adotar o nível de cuidado fixado a fim de minimizar seus custos (SHAVELL, 2003, Capítulo 2 - p.4).

Desse modo, constata-se que a regra de responsabilidade subjetiva cria incentivos para a adoção de nível ótimo de precaução, fazendo com que o objetivo do autor coincida com o objetivo social de minimizar as perdas com acidentes.

Conclui-se que, em contexto de acidentes unilaterais, a regra de ausência de responsabilidade não proporciona incentivos para que o autor adote nível ótimo de precaução. Por outro lado, as regras de responsabilidade objetiva e subjetiva criam incentivos para que ele o adote ${ }^{62}$. Contudo, a escolha entre uma regra e outra tem implicações distintas no que se refere à alocação de risco, à distribuição de recursos entre autor e vítima e à geração de custos administrativos ${ }^{63}$.

Além do nível de precaução que escolham adotar, as partes também podem afetar a probabilidade de acidentes quando alteram a frequência ou a intensidade com que desenvolvem suas atividades. $\mathrm{O}$ risco de acidentes pode ser reduzido pela adoção de medidas de precaução ou pela redução do nível de atividade.

O modelo formal de análise econômica que considera a influência do nível de atividade do autor assume que o seu aumento resulta em: 1) um incremento da utilidade dela decorrente; e 2) um aumento proporcional da probabilidade de ocorrência de danos. Considere que o objetivo social seja a maximização da utilidade que o autor retira de sua atividade menos os custos sociais totais (gastos com precaução e danos esperados) ${ }^{64}$.

Como antes, para que o bem-estar social seja maximizado, o autor deve adotar um nível de precaução que reduza os seus custos. Agora, também terá que optar por um nível de atividade apropriado, ou seja, que pondere a utilidade que obtém e o risco adicional que cria. Observe o exemplo descrito na tabela 2. Suponha que o autor adote o nível ótimo de precaução exposto na tabela 1 (custo de precaução $=3$ ) e que a adoção de mais uma unidade de precaução reduzirá os danos esperados em \$10 (SHAVELL, 2003, Capítulo 2 - p.13):

\footnotetext{
${ }^{62}$ Michael Faure, em citação realizada por Eugênio Battesine, destaca que, "se o cuidado da vítima não tem influência sobre o risco de acidentes e apenas o autor influencia o risco, ambas, as regras de negligência e de responsabilidade objetiva, vão conduzir a um resultado eficiente" (BATTESINI, 2011, p. 132).

${ }^{63} \mathrm{~A}$ adoção entre uma regra e outra também enseja uma discussão sobre justiça. Vasco Rodrigues ressalta que um regime de responsabilidade objetiva, "ao obrigar o causador a suportar danos que eventualmente não estava ao seu alcance evitar, é muitas vezes sentido como injusto". No entanto, em contexto de acidentes unilaterais, "não é óbvio em que sentido um regime de responsabilidade por negligência é mais justo", pois "isentar o causador de responsabilidade implica atribuí-la à vítima" e esta "nada podia fazer para evitar o acidente" (RODRIGUES, 2007, p.94).

${ }^{64}$ Incorporando ao modelo que considera o nível de precaução, em contexto de acidentes unilaterais, considere o nível de ativida de do autor y e o nível de utilidade U proporcionada por ela, tem-se que: a probabilidade de acidentes é função crescente do nível de atividade adotado pelo autor. Suponha que este adota nível constante de precaução (o nível moderado - custo igual a \$3), de modo que, se o autor desenvolve a sua atividade duas vezes, o seu custo de prevenção será igual a \$6 e assim por diante. O custo total de precaução do autor será descrito por c.x.y e o dano total por p(x;y).D (danos esperados, considerando o nível de precaução e o nível de atividade). O bem-estar social, agora, será descrito por BS, que equivalerá a $\mathrm{U}$ - [c.x.y + p(x;y).D], ou seja, será determinado pela utilidade proporcionada pela atividade menos a soma dos custos totais com precaução e dos danos esperados com o acidente.
} 


\begin{tabular}{|c|c|c|c|c|}
\hline $\begin{array}{c}\text { Nível de } \\
\text { atividade }\end{array}$ & Utilidade total & $\begin{array}{c}\text { Custos de } \\
\text { precaução }\end{array}$ & $\begin{array}{c}\text { Dano total com } \\
\text { acidentes }\end{array}$ & Bem-estar social \\
\hline 0 & 0 & 0 & 0 & 0 \\
\hline 1 & 40 & 3 & 10 & 27 \\
\hline 2 & 60 & 6 & 20 & 34 \\
\hline 3 & 69 & 9 & 30 & 30 \\
\hline 4 & 71 & 12 & 40 & 19 \\
\hline 5 & 70 & 15 & 50 & 5 \\
\hline
\end{tabular}

Fonte: SHAVELL, Steven. Analysis of Accident Law. Foundation of Economic Analysis of Law. 2003, Capítulo $2-$ p. 13.

Observa-se que o nível ótimo de atividade é o 2, no qual o benefício social é o mais elevado (34). Cada vez que o autor empreende a sua atividade, ele aumenta os custos sociais totais em $13(10+3)^{65}$. Desse modo, o bem-estar social somente será atingido quando empreende a sua atividade mais uma vez, se a sua utilidade marginal exceder 13. A utilidade que ele obtém quando desenvolve a sua atividade pela primeira vez é igual a 40; logo, a utilidade marginal quando ele a empreende mais uma vez será igual a 20 (60 - 40), e pela terceira vez será igual a $9(69$ - 60). Portanto, o nível dois oferece a melhor opção para o autor (SHAVELL, 2003, Capítulo 2 - p. 13).

Steven Shavell aponta que esse exemplo ilustra que o comportamento socialmente ótimo pode ser determinado a partir de dois passos: primeiro, descobrir qual é o nível ótimo de precaução (que minimiza os custos sociais totais cada vez que o autor empreende a sua atividade); segundo, aumentar o nível de atividade até o limite em que a sua utilidade marginal seja superior aos custos decorrentes do acidente.

Apresentado o modelo formal que considera tanto o nível de precaução quanto o de atividade e caracterizada a existência de um nível ótimo para ambas as variáveis, em contexto de acidentes unilaterais, passa-se a considerar os incentivos que o sistema jurídico oferece ao autor para que ele o adote.

Sob a regra de ausência de responsabilidade, o autor não tem incentivos para adotar qualquer medida de precaução, bem como para considerar os efeitos do nível de sua atividade sobre os danos esperados com acidentes, uma vez que não responde pelos prejuízos causados.

\footnotetext{
${ }^{65}$ Nível 1 de atividade $\rightarrow$ custos sociais totais é igual a $3+10=13$. Nível $2 \rightarrow 6+20=26$. Nível $3 \rightarrow 9+30=39$ e assim por diante
} 
Ademais, o autor optará pelo nível de atividade que maximize o seu retorno privado, ou seja, a opção que lhe proporciona maior utilidade (no exemplo considerado, seria o nível 4).

Por outro lado, quando se tratar de um regime de responsabilidade objetiva, o autor tem incentivos para considerar os efeitos do nível de atividade sobre os danos esperados com acidentes, visto que responde pelo prejuízo causado. Desse modo, ele optará por adotar o nível ótimo de precaução ${ }^{66}$. "Quanto à atividade, a opção do autor será pelo nível que maximiza o seu retorno privado, qual seja, a que lhe proporciona o maior benefício social líquido [utilidade deduzidos os custos de precaução e o dano esperado]” (BATTESINI, 2011, p. 147). Conclui-se que, diante da regra de responsabilidade objetiva, o autor terá incentivos para adotar os níveis de precaução e de atividade socialmente ótimos, ou seja, que maximizem o bem-estar social ${ }^{67}$.

Sob a regra de responsabilidade subjetiva, entretanto, o autor não tem incentivos para considerar os efeitos do nível de atividade sobre os danos esperados com acidentes. Isso se deve ao fato de que somente será responsável pela reparação dos danos caso não tenha observado os padrões mínimos de precaução estabelecidos pelo sistema jurídico. Quanto ao nível de atividade, o autor optará por aquele que maximiza o seu retorno privado, ou seja, o que lhe proporciona o maior benefício líquido. Conclui-se, portanto, que a regra de responsabilidade subjetiva proporciona incentivos para que o autor adote o nível ótimo de precaução, mas não o nível ótimo de atividade.

Verifica-se que, em contexto de acidente unilateral, a regra de ausência de responsabilidade não proporciona incentivos para que os níveis ótimos de precaução e de atividade sejam adotados. A regra de responsabilidade subjetiva fornece incentivos para a adoção do primeiro, mas não do segundo. A regra de responsabilidade objetiva, por sua vez, fornece incentivos adequados para que o autor adote tanto o nível ótimo de precaução quanto o nível ótimo de atividade.

Sob a perspectiva econômica, se os níveis de precaução e de atividade da vítima não influenciam o risco de acidentes, mas a conduta do autor é determinante, a responsabilidade objetiva será mais eficiente e superior à regra de responsabilidade subjetiva, que, por sua vez, será superior à ausência de responsabilização. Em trecho citado por Eugênio Battesini, Gérman Coloma sustenta que:

a maior eficiência que exibem os regimes baseados na responsabilidade objetiva provém do fato de que ditos sistemas não permitem transferir ao danificado nenhum

\footnotetext{
${ }^{66}$ Se o padrão mínimo de cuidado exigível for igual ao nível ótimo.

${ }^{67} \mathrm{O}$ nível de atividade em que o autor obterá o maior benefício líquido (utilidade menos custos de precaução e danos esperados) corresponderá ao nível de maior bem-estar social (34).
} 
dos custos que os acidentes provoca, e fazem, portanto, que o autor do fato ilícito "internalize" todos os riscos que gera. [...] Os regimes baseados na responsabilidade subjetiva, ao invés, criam uma externalidade que não é levada em conta pelo autor: o maior risco provocado por um maior nível de atividade ${ }^{68}$ (BATTESINI, 2011, p.148).

Vasco Rodrigues vislumbra duas razões para tanto. A primeira razão se refere ao fato de que a responsabilidade subjetiva só resulta em um comportamento eficiente se este for definido como comportamento padrão pelo legislador (ou pelos tribunais), pois o potencial autor tenderá a adotar o comportamento que lhe for exigido (desde que os custos com a adoção da precaução sejam inferiores aos danos decorrentes do dano que terá que reparar). Contudo, o sistema jurídico não dispõe de informações suficientes para determiná-lo de forma precisa $^{69}$. A segunda razão diz respeito aos custos com a sua implementação, particularmente, se o comportamento do potencial autor envolver aspectos difíceis, ou impossíveis, de serem observados (RODRIGUES, 2007, p. 97).

\subsection{Acidentes Bilaterais}

Em acidentes bilaterais, a vítima e o potencial autor podem adotar medidas para reduzir a probabilidade e a severidade dos danos, e a eficiência exige que ambos o façam. $\mathrm{O}$ exemplo mais comum são os acidentes de trânsito, nos quais, com frequência, ambas as partes podem atuar de maneira preventiva.

Steven Shavell sustenta que a versão formal do modelo que considera o nível de precaução em acidentes bilaterais é uma extensão natural do modelo anterior ${ }^{70}$. Agora, a determinação dos níveis ótimos de precaução assume caráter bilateral, ou seja, tanto o do autor quanto o da vítima devem ser identificados.

\footnotetext{
${ }^{68}$ Este inconveniente da responsabilidade subjetiva poderia ser evitado se o comportamento padrão também incluísse um determinado nível de atividade. Esta não é, no entanto, uma solução habitual, pois o legislador se depararia com algumas dificuldades: 1) para estabelecer o nível de atividade eficiente precisaria conhecer não só os custos associados aos acidentes como os benefícios gerados pela atividade; 2) uma vez consumado o acidente, o tribunal precisaria examinar não só o nível de precaução do causador como também o seu nível de atividade (RODRIGUES, 2007, p.108).

${ }^{69}$ Ele acrescenta que "uma complicação adicional, nesta matéria, é que o comportamento eficiente não é igual para todos os indivíduos porque as precauções podem ter custos diferentes para diferentes indivíduos. Por exemplo, o comportamento eficiente do Fernando Alonso na estrada é, presumivelmente, diferente do meu. A defesa do interesse do conjunto da sociedade exigiria, por isso, a definição de comportamentos padrão diferentes para diferentes indivíduos. Mas fazê-lo envolve dificuldades muito substanciais, tanto a nível da definição dos padrões, como da verificação do seu cumprimento. O comportamento padrão é, por isso, normalmente definido de forma única, tendo em conta o comportamento que poderia ser esperado de uma pessoa razoável com capacidades normais" (RODRIGUES, 2007, p.96)

${ }^{70}$ Potenciais autores escolherão o nível de cuidado $\mathrm{x}_{\mathrm{a}}$, as vítimas escolherão o nível $\mathrm{x}_{\mathrm{v}}$, a probabilidade de acidente é $\mathrm{p}\left(\mathrm{x}_{\mathrm{a}}\right.$, $\left.\mathrm{x}_{\mathrm{v}}\right)$, o custo por unidade de precaução é $c_{a}$ e $c_{v}$, respectivamente, para o autor e para a vítima, e o objetivo social é minimizar $\left(c_{a} \cdot x_{a}+c_{v} \cdot x_{v}\right)+p\left(x_{a}, x_{v}\right) \cdot D$. Assume-se que os níveis ótimos de cuidado $\mathrm{x}_{\mathrm{a}}{ }^{*} \mathrm{e} \mathrm{x}_{\mathrm{v}}{ }^{*}$ são positivos e únicos. Como mencionado anteriormente, tais níveis podem ser determinados quando os custos marginais (associados aos níveis de precaução adotados pelo autor e pela vítima) se igualam aos respectivos benefícios marginais (associados à redução dos danos esperados), $\left(\mathrm{c}_{\mathrm{a}} \cdot \mathrm{X}_{\mathrm{a}}\right)+\left(\mathrm{c}_{\mathrm{v}} \cdot \mathrm{x}_{\mathrm{v}}\right)=-\mathrm{p}\left(\mathrm{x}_{\mathrm{a}}, \mathrm{x}_{\mathrm{v}}\right)$.D (BATTESINI, 2011; COOTER e ULEN, 2010; SHAVELL, 2003).
} 
O objetivo social continua sendo a minimização dos custos sociais totais que, em contexto de acidentes bilaterais, equivalem ao somatório dos custos de precaução do autor e da vítima e dos danos esperados. Assume-se que os níveis ótimos de cuidado das partes refletem a sua possibilidade conjunta de redução dos riscos de acidente e de seus gastos com prevenção (SHAVELL, 2003, Capítulo 2 - p.5). Para simplificar a análise, suponha que, em vez de três níveis de precaução, há somente dois, adotar medidas de cuidado ou não. O prejuízo é igual a $\$ 100$. Considere a tabela 3 a seguir:

\begin{tabular}{|c|c|c|c|c|c|c|}
\hline \multicolumn{2}{|c|}{$\begin{array}{c}\text { Nível de precaução } \\
\text { autor }\end{array}$} & \multicolumn{2}{c|}{$\begin{array}{c}\text { Custo de precaução } \\
\text { vítima }\end{array}$} & $\begin{array}{c}\text { Probabilidade } \\
\text { de acidente }\end{array}$ & $\begin{array}{c}\text { Dano } \\
\text { esperado }\end{array}$ & $\begin{array}{c}\text { Custos } \\
\text { sociais } \\
\text { totais }\end{array}$ \\
\hline Nenhuma & Nenhuma & 0 & 0 & $15 \%$ & 15 & 15 \\
\hline Nenhuma & Precaução & 0 & 2 & $12 \%$ & 12 & 14 \\
\hline Precaução & Nenhuma & 3 & 0 & $10 \%$ & 10 & 13 \\
\hline Precaução & Precaução & 3 & 2 & $6 \%$ & 6 & 11 \\
\hline
\end{tabular}

Fonte: SHAVELL, Steven. Analysis of Accident Law. Foundation of Economic Analysis of Law. 2003, Capítulo $2-$ p.5.

Nota-se que o nível ótimo ocorre quando ambas as partes adotam medidas de precaução (os custos sociais totais são iguais a 11). Quando somente o autor as adota, os danos esperados equivalerão a 10. Por outro lado, se a vítima também se prevenir, a um custo de 2, os danos esperados reduzirão em 4. Entretanto, há outros exemplos nos quais somente o autor pode tomar medidas de cuidado ou somente a vítima (ou nenhum deles). Essas possibilidades não serão trabalhadas porque a maioria das situações reais exige que ambas as partes adotem medidas preventivas (SHAVELL, 2003, Capítulo $2-$ p.5).

Em acidentes bilaterais, frequentemente, a maneira como uma parte se comporta dependerá do comportamento da outra. Por exemplo, em acidentes de trânsito, a atenção dos motoristas em relação aos ciclistas tende a depender do grau de cautela com que estes estão a guiar, e vice-versa. O fato de autor e vítima interagirem, "seja de forma cooperativa, conflituosa ou simplesmente não cooperativa, permite que a determinação dos níveis ótimos de precaução possa, também, ser realizada mediante utilização da teoria dos jogos ${ }^{71,}$ (BATTESINI, 2011, p. 135). Considere a tabela 4:

\footnotetext{
${ }^{71}$ Desenvolvida a partir das contribuições de John von Neumann, Oskar Morgenstern e John Nash, a teoria dos jogos é uma ferramenta matemática utilizada no estudo da interação estratégica entre pessoas, em situações nas quais a escolha de um indivíduo depende da escolha de outro e vice-versa (MACKAAY, 2000, P.91). Heico Kerkmeester, em trecho citado por Eugênio Battesini, aduz que a "ideia básica inerente à teoria dos jogos é a de que situações de interação social podem ser modeladas como jogos, como xadrez ou pôquer, dado que os
} 


\begin{tabular}{|c|c|c|c|}
\hline Nível precaução & Vítima - baixo (0) & Vítima - médio (2) & Vítima - elevado (4) \\
\hline Autor - baixo (0) & $20(20)$ & $17(19)$ & $14(18)$ \\
\hline Autor - médio (2) & $15(17)$ & $12(16)$ & $11(17)$ \\
\hline Autor - elevado (4) & $12,5(16,5)$ & $11(17)$ & $10(18)$ \\
\hline
\end{tabular}

Fonte: BATTESINI, Eugênio. Direito e Economia: Novos Horizontes no Estudo da Responsabilidade Civil no Brasil. p. 135.

As estratégias do autor e da vítima podem ser a adoção do nível de precaução baixo, médio ou elevado, sendo que os respectivos custos das estratégias (custos com a prevenção) estão indicados nos parênteses próximos. Os resultados das combinações estratégicas são apresentados ao centro, com indicação dos danos esperados e, entre parênteses, dos custos agregados (soma dos danos esperados e dos custos das estratégias de precaução do autor e vítima) (BATTESINI, 2011, p. 135).

Consta-se que o nível eficiente de precaução ocorre quando o autor e a vítima optam pela adoção simultânea do nível médio de precaução (os custos sociais esperados são 16). Frequentemente, tal escolha também representa a melhor estratégia para as partes, uma combinação em que ambas contam com incentivos para aderir. Fala-se em um equilíbrio de Nash (BATTESINI, 2011, p. 135).

Apresentado o modelo formal que considera os níveis de precaução de ambas as partes, e caracterizada a existência de um nível ótimo de cuidado (conjunto), passa-se a analisar os incentivos criados pelas regras de responsabilização para que autor e vítima o adotem.

A regra de ausência de responsabilidade civil faz com que a vítima internalize os custos totais do dano e o autor o externalize, de modo que este não terá incentivos eficientes para adotar medidas de cuidado. A vítima, por outro lado, terá incentivos para se prevenir, uma vez que arcará com os prejuízos decorrentes do acidente ${ }^{72}$. Isto ocorre tanto nos acidentes unilaterais quanto nos bilaterais. A partir de tais considerações, é possível concluir que a ausência de responsabilidade não constitui mecanismo eficiente para a prevenção de acidentes.

indivíduos interagem, possuem diversas alternativas de ação e realizam escolhas sobre como agir tentando obter o melhor resultado para si, levando em consideração as possíveis ações dos outros indivíduos". O seu objetivo é prever as escolhas estratégicas que os jogadores irão realizar, ou seja, a solução do jogo. Para tanto, dois conceitos são fundamentais: o de estratégia dominante e o de equilíbrio de Nash. Diz-se que uma estratégia é dominante quando a melhor resposta de um jogador é a mesma independentemente das demais. O equilíbrio de Nash, por sua vez, ocorre quando a estratégia de cada jogador é a melhor resposta à estratégia do outro (BATTESINI, 2011, p. 81-82).

${ }^{72}$ Constata-se que a estratégia dominante, dada pelo autor, é a adoção do nível baixo de cuidado, o que faz com que a vítima opte pela adoção de nível de precaução elevado, uma combinação estratégica que não conduz a um equilíbrio eficiente (BATTESINI, 2011, p. 136). 
Sob a regra de responsabilidade objetiva, o autor arcará com os danos decorrentes de um eventual acidente, por isso terá incentivos para adotar medidas de prevenção. A vítima, por outro lado, não o terá ${ }^{73}$. Verifica-se que a regra de responsabilidade objetiva não constitui mecanismo eficiente de prevenção de acidentes, visto que não cria incentivos para que a vítima também adote medidas de cuidado.

No entanto, a possibilidade de exclusão do nexo de imputação ou do nexo causal por culpa da vítima (respectivamente, culpa contributiva e culpa exclusiva da vítima), bem como de redução do montante indenizatório proporcional a sua culpa, modificam a alocação do risco de danos. Assim, os incentivos para autor e vítima se prevenirem se alteram. Na defesa da negligência contributiva (contributory negligence), por exemplo, se a vítima adotar nível de cuidado inferior ao fixado pelo sistema jurídico (considere que o parâmetro estabelecido seja equivalente ao nível ótimo de precaução), o autor não será considerado responsável e os danos com acidentes recairão sobre ela. Por outro lado, se adotar o mínimo de cuidado exigido, a responsabilidade do autor prevalecerá ${ }^{74}$.

Quando há a possibilidade de redução do montante indenizatório proporcional à culpa da vítima, cada um dos envolvidos responderá por parte do dano, levando em conta a sua contribuição para a ocorrência do acidente. Considere que o sistema jurídico estabeleça um parâmetro de cuidado equivalente ao nível ótimo de precaução. Se a vítima adotar um nível inferior ao ótimo, os danos serão repartidos considerando a sua proporção de culpa. Assim, ela também terá incentivos para se prevenir ${ }^{75}$. Conclui-se que, em contexto de acidentes bilaterais, a regra de responsabilidade objetiva com redução do valor da indenização proporcional à culpa cria incentivos para que as partes adotem o devido cuidado.

Sob a regra de responsabilidade subjetiva, como já mencionado, o autor adotará medidas preventivas a fim de se exonerar da reparação de eventual dano que venha a ocorrer em virtude de sua atividade. Considere que o sistema jurídico estabeleça um parâmetro mínimo de cuidado equivalente ao nível ótimo de prevenção. Se o autor não o adotar, ele será responsável pela reparação dos danos. Contudo, se adotar um nível de precaução igual ou

\footnotetext{
73 Agora, a estratégia dominante, dada pela vítima, é a adoção de um nível baixo de cuidado, o que faz com que o autor opte pelo nível elevado de precaução, uma combinação estratégica que não conduz a um equilíbrio eficiente (BATTESINI, 2011, p. 137). Steven Shavell ressalta que, no entanto, as vítimas teriam incentivos para adotar medidas de cuidado se não fossem ou não pudessem ser plenamente compensadas por suas perdas, como quando envolve a possibilidade de ferimentos graves ou morte (SHAVELL, 2003, Capítulo 2 - p.6).

${ }^{74}$ Quando há a possibilidade de defesa que leve em conta o grau de culpa da vítima, a estratégia dominante, dada por ela, será a adoção do nível médio de precaução, o que faz com que o autor também opte por adotar o nível médio de precaução. Esta combinação conduz a um equilíbrio eficiente e também se apresenta como a melhor estratégia para ambos, uma vez que tanto o autor quanto a vítima contam com incentivos para atuar nesse sentido. Trata-se, então, de um equilíbrio de Nash (BATTESINI, 2011, p.138).

${ }^{75}$ Novamente, a estratégia dominante, dada pela vítima, é a adoção do nível médio de precaução, o que faz com que o autor também o adote. Essa combinação estratégica conduzirá a um equilíbrio eficiente (BATTESINI, 2011, p.138).
} 
superior ao ótimo, ele não será responsabilizado ${ }^{76}$. Diante disso, a vítima também irá se prevenir, uma vez que, assumindo que o autor também o faça, ela terá que arcar com os eventuais prejuízos. Portanto, a regra de responsabilidade subjetiva também criará incentivos para que as partes envolvidas em atividades de risco adotem medidas preventivas.

Quando há a previsão de defesa (exclusão do nexo de imputação ou do nexo de causalidade, redução do valor indenizatório proporcional à culpa da vítima, entre outras) aliada a uma regra de responsabilidade, a alocação do risco é modificada, bem como os incentivos para a adoção de medidas preventivas por parte do autor e da vítima. Sob uma regra de responsabilidade objetiva com possibilidade de defesa, ambos os envolvidos na atividade de risco irão se prevenir. Contudo, Steven Shavell ressalta que a previsão de tais defesas é uma adição desnecessária à regra de responsabilidade subjetiva no que diz respeito à geração de incentivos para que a vítima adote medidas de prevenção:

[...] pois as vítimas já atuam nesse sentido quando a regra vem desacompanhada da defesa. Sob a regra de responsabilidade subjetiva simples, potenciais autores adotam o devido cuidado para evitar a responsabilização. Consequentemente, as vítimas suportarão os seus prejuízos, o que lhes proporciona incentivos para que também adotem o cuidado apropriado. Portanto, não há a necessidade de fornecer outros incentivos para que adotem o devido cuidado (SHAVELL, 2003, Capítulo 2 - p.8).

O regime de responsabilidade objetiva, em contexto de acidentes bilaterais, não conduz a um resultado socialmente ótimo, pois falha ao não criar incentivos para que a vítima atue de modo a evitar o risco de acidentes. Por isso, torna-se necessária a adição de outros mecanismos para que ela também adote o nível ótimo de cuidado ${ }^{77}$.

Conclui-se que as regras de responsabilidade subjetiva e objetiva com defesa que leve em consideração o comportamento da vítima criam incentivos para que as partes atuem no sentido de evitar o risco de acidentes. Diante de tal conclusão, a escolha entre uma e outra se desloca, "essencialmente, para o plano da justiça corretiva e da equidade nas relações sociais" $^{, 78}$ (BATTESINI, 2011, p. 144).

Como mencionado na análise dos modelos de acidentes unilaterais, o nível de atividade também tem influência sobre o risco de acidentes. Em contexto de acidentes

\footnotetext{
${ }^{76}$ Agora, a estratégia dominante é dada pelo autor, que adotará o nível ótimo de precaução. Tal conduta faz com que a vítima também adote o nível ótimo de cuidado. Essa combinação estratégica é eficiente e se apresenta como a melhor estratégia para ambos. Logo, eles terão incentivos para aderir a ela (BATTESINI, 2011, p. 139).

${ }^{77}$ Cooter e Ulen sustentam que não é possível "escapar desse dilema dividindo os custos do dano entre vítima e seu causador. Dividir os custos do dano entre eles faz com que cada um deles externalize parte do dano, de modo que ambos tenham incentivos para uma precaução deficiente" (COOTER; ULEN, 2010, p. 337). A melhor alternativa é a adoção de defesas que levem em consideração a conduta da vítima.

${ }^{78}$ É importante destacar que cada regra terá um efeito distinto sobre a alocação dos danos. Sob a regra de responsabilidade subjetiva, a adoção de medidas de cuidado por parte do autor implica a trasladação dos custos do dano para a vítima, bem como, diante da responsabilidade objetiva, os prejuízos são deslocados para o autor. Isso deve ser levado em consideração na escolha entre uma regra e outra, pois, como ressalta Vasco Rodrigues, "o acidente gera custos pelos quais alguém tem que responder; se não é o causador, é a vítima" (RODRIGUES, 2007, p. 92).
} 
bilaterais, os níveis de atividade da vítima e do autor influenciam a probabilidade e a severidade dos danos.

Considere que um aumento no nível de atividade do autor e da vítima, aumenta a utilidade de ambos, mas também resulta em um incremento proporcional da probabilidade de acidentes. Assim, se um ciclista percorre mais um quilômetro, ele aumenta a sua utilidade, porém as chances de se envolver em um acidente também aumentam.

Sob a regra de responsabilidade objetiva com defesa que considere a conduta da vítima, autor e vítima têm incentivos para adotar o nível ótimo de precaução ${ }^{79}$. Diante de tal disposição legal, caso a vítima adote o mínimo de cuidado exigível, os danos serão suportados pelo autor. Logo, ele terá incentivos para adotar o nível ótimo de precaução, bem como o de atividade. Por outro lado, na medida em que a vítima é compensada pelos prejuízos que sofre, ela pode vir a desenvolver sua atividade de maneira demasiada ${ }^{80}$. Portanto, a responsabilidade objetiva com defesa que considere a conduta da vítima fornece incentivos para que ela adote o nível ótimo de cuidado, mas não o de atividade.

A regra de responsabilidade subjetiva também cria incentivos para que as partes envolvidas em atividades de risco adotem níveis ótimos de precaução. Contudo, como o autor não será responsabilizado caso adote o nível de cuidado estabelecido, ele pode vir a desenvolver a sua atividade de forma demasiada. A vítima, por outro lado, diante da conduta do autor, optará por adotar o nível adequado de atividade, pois suportará seus próprios prejuízos $^{81}$.

Nota-se que não há regra de responsabilidade que proporcione incentivos para que a vítima e o autor adotem, simultaneamente, nível ótimo de atividade:

Essencialmente, o problema é que, para os autores serem induzidos a escolher o nível correto de atividade, eles devem suportar todas as perdas dos acidentes; e para que as vítimas escolham o nível correto de atividade, elas também devem suportar todas as perdas dos acidentes. No entanto, é da natureza das normas de responsabilidade que ambas as condições não podem ser mantidas simultaneamente, pois autor e vítima não pode cada um suportar todas as perdas do acidente ${ }^{82}$ (SHAVELL, 1980, p.7).

A escolha entre uma regra e outra dependerá do que for considerado mais benéfico para uma sociedade: reduzir o nível de atividade da vítima ou do autor. Isso dependerá de

\footnotetext{
${ }^{79}$ Caso o sistema jurídico estabeleça que o padrão de precaução exigível seja equivalente ao nível ótimo.

${ }^{80}$ A vítima empreenderá a sua atividade sempre que a utilidade dela decorrente for superior aos custos com precaução.

${ }^{81}$ Empreenderá sua atividade até o ponto em que o dano esperado supere o proveito dela decorrente.

${ }^{82}$ De acordo com Steven Shavell, três pontos podem ser levantados a partir dessa conclusão. Primeiro, outros métodos (diferentes da responsabilidade civil) podem conduzir a um nível ótimo de atividade. Por exemplo, suponha que o autor pague multas ao Estado equivalente aos danos que cause ou impostos que levem em consideração os danos esperados; e a vítima arque com os seus prejuízos. Assim, ambos adotariam níveis de cuidado e de atividade ótimos. Segundo, essa conclusão depende da suposição de que o sistema jurídico não pode incorporar o nível de atividade ao conceito de culpa. Terceiro, isso não deve ser interpretado como algo negativo, pois quanto mais variáveis são incorporadas ao modelo original, menos provável será a consecução do resultado ideal. (SHAVELL, 2003, Capítulo 2 - p.20)
} 
cada caso. Por exemplo, quando a atividade do potencial autor cria riscos substanciais, apesar da adoção de medidas de cuidado, é socialmente desejável que seja controlada.

Cooter e Ulen ressaltam que, de fato, há dificuldades em alcançar dois objetivos (aumentar a precaução e reduzir o nível de atividades perigosas) com uma única política pública. Normalmente, recorre-se a dois mecanismos, como a responsabilidade civil e a tributação (COOTER; ULEN, 2010, p. 344).

\subsection{Flexibilização dos pressupostos considerados nos modelos}

Uma nova análise dos efeitos das regras de responsabilidade civil pode ser realizada com a incorporação de outros fatores como o nível de informação sobre o risco da atividade, a influência dos seguros e dos custos administrativos. A flexibilização de determinados pressupostos dos modelos teóricos básicos "permite evidenciar como opera o sistema de responsabilidade civil quando se consideram dimensões mais amplas do que o nível de precaução e o nível de atividade das partes envolvidas em atividades com risco de acidente" (BATTESINI, 2011, p.156).

Agora, o rigor formal dos modelos é amenizado de modo a considerar que as partes contam com diferentes níveis de informação acerca da probabilidade e severidade dos danos; diferentes níveis de aversão ao risco, bem como que suas escolhas são influenciadas pelos custos administrativos ${ }^{83}$. Desse modo, os modelos "ganham em complexidade e perdem em poder preditivo à medida que novas variáveis são incorporadas à análise" (BATTESINI, 2011, p. 156).

\subsubsection{Nível de informação}

O primeiro pressuposto a ser flexibilizado é o de que autor e vítima são perfeitamente informados acerca da probabilidade e da severidade dos danos associados aos diversos níveis de precaução e de atividade. É importante destacar que o nível de informação de que dispõem terá impacto sobre o funcionamento do sistema jurídico de alocação de danos.

\footnotetext{
${ }^{83}$ Neste trabalho, não será abordada a flexibilização dos pressupostos da racionalidade e da existência de outras políticas públicas que atuem sobre o número de acidentes.
} 
A partir dessa análise é possível ingressar em um novo campo de investigação: as relações de mercado. Por exemplo, o nível de informação dos consumidores será relevante tanto para a eficiência dos incentivos proporcionados pelas regras de responsabilização quanto para a própria dinâmica mercadológica.

Para a análise das implicações do nível de informação, bem como de sua distribuição entre as partes envolvidas em uma atividade com risco de acidentes, considere que: o autor é uma empresa que comercializa seus produtos ou serviços em um mercado competitivo e que a vítima se relaciona com a empresa contratualmente ou via sistema de preços (consumidor). A distribuição de informações pode ser simétrica (quando as partes são perfeitamente informadas sobre o risco da atividade) ou assimétrica (quando o autor é perfeitamente informado e a vítima dispõe de informação imperfeita, subestimando os riscos inerentes à atividade).

Novas variáveis também serão consideradas neste novo contexto: o preço e os custos de produção dos produtos. O bem-estar social, agora, levará em consideração os custos e benefícios sociais associados à produção e equivalerá à soma das utilidades de todas as partes envolvidas em atividades com risco de acidentes (empresas, consumidores, entre outras), deduzidos os respectivos custos de prevenção e danos esperados.

O principal aspecto da análise é que a disposição dos consumidores em adquirir um produto ou serviço será afetada por sua percepção sobre a situação de risco. Desse modo, as empresas contam com incentivos para reduzi-lo, não apenas para evitar a responsabilização, mas também para ganhar competitividade (BATTESINI, 2011, p. 158).

Mitchell Polinsky explora um exemplo bastante didático, que ajudará a entender como o nível de informação do consumidor acerca da situação de risco interage com o sistema de responsabilidade civil.

Uma fábrica produz dois tipos de refrigerantes: em lata e em garrafa. Considere que os consumidores não têm preferência entre um e outro; logo, o preço será o único fator relevante para a sua decisão. A produção do refrigerante em garrafa é mais barata, o custo por unidade equivale a $\$ 0,40$. O refrigerante em lata, por sua vez, custa $\$ 0,43$. Contudo, o primeiro tem o dobro de probabilidade de causar acidente quando comparado com o segundo (respectivamente, 1 caso a cada 100.000 produtos vendidos e 1 caso a cada 200.000). Cabe ressaltar que os danos causados por refrigerantes em garrafa são mais graves do que os causados por refrigerantes em lata, de modo que os prejuízos equivalem, respectivamente, a $\$ 10.000$ e $\$ 4.000$. 
Assim, constata-se que o dano esperado com acidentes por unidade de produção é maior para as garrafas do que para as latas, respectivamente, $\$ 0,10$ e $\$ 0,02$. Conclui-se que o custo total por unidade de produto é maior para as garrafas do que para as latas, respectivamente, $\$ 0,50$ e $\$ 0,45$ (soma do custo unitário de produção e do custo esperado com acidentes por unidade). Sob a perspectiva da maximização do bem-estar social, é preferível a produção de refrigerante em lata, uma vez que apresenta menor custo total unitário (BATTESINI, 2011, p.158).

Suponha que, quando os consumidores dispõem de informação perfeita, eles terão conhecimento dos riscos oferecidos pelos produtos, bem como dos custos esperados com acidentes. Além disso, serão capazes de identificar se o preço do produto reflete ou não o potencial risco de acidentes.

Considere que o preço do produto equivale ao custo unitário total (não são considerados outros fatores, tais como a margem de lucro do fabricante). Assim, no exemplo mencionado, o comportamento dos consumidores será pautado pelos dados traduzidos no preço integral ( $\$ 0,50$ e $\$ 0,45$, respectivamente, os preços integrais do refrigerante em garrafa e em lata).

Primeiramente, serão analisados os efeitos das regras de responsabilidade civil quando os consumidores contam com informação perfeita acerca do risco. Em tal contexto, as empresas serão conduzidas a adotar um nível ótimo de cuidado ${ }^{84}$ até mesmo diante da ausência de responsabilização.

Sob este regime, os danos decorrentes de eventuais acidentes serão suportados pelos consumidores. No entanto, como são capazes de identificar se o preço dos produtos reflete o potencial risco de acidentes, optam por aquele que apresenta o menor preço integral. No exemplo considerado, a opção que maximiza a sua utilidade será o refrigerante em lata, que apresenta menor preço integral $(\$ 0,45)$.

As empresas terão incentivos para disponibilizar no mercado produtos cujos preços reflitam os custos diretos de produção e os danos esperados com acidentes:

Se as empresas adotam o nível de cuidado inferior ao exigido, seus consumidores potenciais irão identificar tal situação [...] Consequentemente, eles irão procurar os produtos de seu interesse em outro lugar, ou seja, irão optar por comprar das empresas concorrentes que adotam o devido cuidado e ofereçam os produtos a preços integrais mais baixos, embora a um preço de mercado mais alto (SHAVELL, 2003, Capítulo 3 - p.5).

\footnotetext{
${ }^{84}$ Considere que o nível de precaução adotado pela empresa reflete o nível de confiabilidade e de segurança dos produtos levados ao mercado.
} 
Steven Shavell sustenta que a força da concorrência conduzirá as empresas a adotar o nível ótimo de precaução não apenas diante da ausência de responsabilização, mas igualmente diante da responsabilidade subjetiva e da responsabilidade objetiva ${ }^{85}$ (SHAVELL, 2003, Capítulo 3 - p. 5). Os consumidores também adotarão o nível ótimo de cuidado, uma vez que conhecem os potenciais riscos com acidente. Ademais, a dinâmica de mercado também ensejará resultados eficientes quanto ao nível de atividade da empresa, pois os consumidores comprarão uma quantidade socialmente ótima de produtos, independentemente da ausência ou presença de responsabilidade civil. Isso se deve ao fato de que só adquirirão os produtos se os seus respectivos preços refletirem o potencial risco de acidente.

Conclui-se que, quando os consumidores dispõem de informação perfeita, o próprio mercado proporcionará resultados eficientes quanto aos níveis de precaução e de atividade da empresa, seja qual for o regime de responsabilidade adotado.

No entanto, quando a percepção dos consumidores acerca dos riscos inerentes a um produto é deficiente, os incentivos criados pelas regras de responsabilidade são significativamente alterados. Em tal contexto, não conseguem identificar se o preço dos produtos comercializados reflete, ou não, o potencial risco de acidentes, bem como o subestimam.

Agora, serão analisados os efeitos das regras de responsabilidade civil quando os consumidores dispõem de informação imperfeita acerca do risco. Diante da ausência de responsabilidade, os danos com acidentes recaem sobre os consumidores. Como mencionado, por não disporem de informações suficientes, subestimam os riscos oferecidos pelos produtos e não identificam se o preço os reflete. Logo, optarão pelo produto menos seguro, que apresenta menor preço de mercado ${ }^{86}$.

Constata-se que as empresas não contarão com incentivos para produzir de forma eficiente, pois disponibilizarão produtos menos seguros no mercado, vendidos a preços que consideram apenas o custo direto de produção. Shavell destaca que "nenhuma empresa desejará incorrer em custos adicionais com a segurança se os consumidores não reconhecem e não as recompensam pagando mais pelos produtos". Portanto, nesse contexto, "a responsabilidade é necessária para induzir as empresas a adotarem o nível ótimo de cuidado" (SHAVELL, 2003, Capítulo 3 - p.6).

\footnotetext{
${ }^{85}$ Eugênio Battesini ressalta que, sob o regime da responsabilidade objetiva, além dos estímulos de mercado, as empresas têm incentivos institucionais para incorporar os custos esperados com acidentes ao preço de mercado (BATTESINI, 2011, p.161). Uma vez que são objetivamente responsáveis por eventuais danos que venham a ocorrer, as empresas optarão por adotar medidas de precaução e diluirão seus respectivos custos nos preços dos produtos. Também adotarão o nível de atividade adequado.

${ }^{86}$ Considerando o exemplo de Polinsky, o consumidor optará pelo refrigerante em garrafa, que é comercializado no mercado a um preço inferior ao refrigerante em lata (respectivamente, $\$ 0,40$ e $\$ 0,43$ ), o que também induzirá um consumo em quantidade excessiva, em face da desconsideração dos custos esperados com acidentes (BATTESINI, 2011, p.162).
} 
Conclui-se que, quando não há responsabilização e o consumidor conta com informação imperfeita, não há incentivos (de mercado ou institucional) para que as empresas adotem níveis de precaução e de atividade ótimos, pois optarão por comercializar produtos menos seguros, em quantidade superior à ótima.

Sob a regra de responsabilidade subjetiva, por outro lado, as empresas contam com incentivos para adotar o nível ótimo de precaução, comercializando produtos mais seguros, a fim de não arcar com a reparação dos danos decorrentes de acidentes. Entretanto, os resultados não serão ótimos quanto ao nível de atividade. Como os consumidores não identificam se os preços dos produtos refletem ou não o potencial de risco, a dinâmica de mercado não fornecerá incentivos para que sejam comercializados a um preço que incorpore o custo esperado com acidentes. Esta situação conduz a um consumo superior à quantidade ótima:

[...] sob ausência de responsabilização ou sob a regra de responsabilidade subjetiva, a aquisição de produtos por parte dos consumidores será superior a quantidade ótima. Se o consumidor superestima os riscos, também superestimará o preço integral e pode decidir não comprar o produto quando, na verdade, a sua utilidade excede o seu preço integral. Se o consumidor subestima os riscos, o problema oposto pode ocorrer; eles podem adquirir mais do que a sua utilidade exigiria (SHAVELL, 2003, Capítulo 3 - p.6).

Portanto, quando os consumidores têm uma percepção deficiente acerca dos riscos envolvidos no consumo de um produto, a regra de responsabilidade subjetiva cria incentivos para a adoção do nível ótimo de precaução, mas não terá êxito quanto à adoção do nível ótimo de atividade.

Sob o regime da responsabilidade objetiva, assim como ocorre quando os consumidores dispõem de informação perfeita, são gerados incentivos para a adoção de níveis ótimos de precaução e de atividade. Na medida em que os danos com os acidentes recaem sobre as empresas, estas terão incentivos para adotar medidas de segurança e optarão por comercializar produtos mais seguros. Por conseguinte, também atuarão de acordo com o nível ótimo de atividade, uma vez que disponibilizarão os produtos no mercado a um preço que incorpora o custo esperado com acidentes (BATTESINI, 2011, p.163). Nesse sentido, Cooter e Ulen destacam que essa conclusão:

[...] oferece a justificativa básica para responsabilizar objetivamente os fabricantes pelo dano que produtos defeituosos causam aos consumidores: o preço da responsabilização será embutido no preço, direcionando, assim, os consumidores para a eficiência apesar de terem informações imperfeitas (COOTER; ULEN, 2010, p.357). 
É importante destacar que, na relação de consumo, a distribuição de informação é assimétrica, pois os fabricantes, via de regra, detêm um conhecimento maior acerca dos riscos envolvidos no consumo de seus produtos quando comparados com os consumidores.

Geralmente, os níveis de precaução e de atividade do consumidor não são tão determinantes em acidentes com produtos, exceto quando se tratar de bens de consumo duráveis, hipótese em que poderia ser considerado o modelo de acidentes bilaterais. Neste contexto, não apenas o nível de precaução adotado pelos consumidores, como também a quantidade de produtos adquiridos e a sua frequência de uso, influenciarão a probabilidade e a severidade os danos decorrentes de eventuais acidentes ${ }^{87}$.

Como mencionado, quando o consumidor dispõe de informação perfeita, ambas as partes adotarão níveis ótimos de precaução e de atividade, independentemente da regra de responsabilidade considerada. Por outro lado, quando o consumidor dispõe de informação imperfeita, verifica-se que as regras de ausência de responsabilidade, de responsabilidade subjetiva e de responsabilidade objetiva não produzem resultados eficientes. No entanto, estes poderão ser obtidos mediante uma regra de responsabilidade objetiva com defesa que considere o comportamento da vítima (exclusão do nexo causal por culpa exclusiva da vítima; redução do valor da indenização proporcional a sua culpa, entre outras). Shavell registra que, na realidade, não há regra de responsabilidade eficiente a ser aplicada nesse contexto (SHAVELL, 2003, Capítulo 3 - p.9).

A regra de responsabilidade objetiva, contudo, pode se revelar socialmente mais desejável quando um dos objetivos ambicionados por uma sociedade for a criação de incentivos para o desenvolvimento de produtos mais seguros (SHAVELL, 2003, Capítulo 3 p.9).

\subsubsection{Nível de aversão ao risco}

O segundo pressuposto dos modelos teóricos a ser flexibilizado é o de que as partes envolvidas em atividades arriscadas são neutras em relação ao risco. Quando adotam a posição de neutralidade perante o risco, tomam as suas decisões considerando apenas os custos e os benefícios envolvidos na atividade. Contudo, muitas vezes, autor e vítima não

\footnotetext{
${ }^{87}$ A probabilidade e a severidade dos danos decorrentes de um acidente com cortador de grama, por exemplo, parecem ser influenciadas não só pelo cuidado adotado pelo consumidor, mas também pela freqüência com que escolhe cortar a grama (BATTESINI, 2011, p. 165).
} 
estão dispostos a assumir riscos, sobretudo quando as perdas esperadas são elevadas (BATTESINI, 2011, p. 171).

Steven Shavell destaca que o problema com acidentes envolve não apenas o objetivo de reduzir os seus riscos, mas também o de alocá-los adequadamente, para que a pessoa avessa ao risco não tenha que suportá-los (SHAVELL, 2003, Capítulo 5 - p.1). A parte que tem aversão ao risco se preocupa não só com o valor esperado do prejuízo, mas também com a sua possível magnitude ${ }^{88}$. Geralmente, esses indivíduos recorrem a mecanismos de proteção como o seguro. Eles podem, inclusive, optar por reduzir o nível de atividade e, em casos mais extremos, deixar de realizar a atividade de risco. Isso afeta "a alocação dos recursos no mercado, a utilidade esperada dos indivíduos e, por consequência, o nível de bem-estar social” (BATTESINI, 2011, p.171):

o bem-estar social depende não apenas dos fatores enfatizados nos capítulos
anteriores - positivamente, os benefícios obtidos pelas partes ao exercerem suas
atividades e, negativamente, os custos de precaução e dos danos esperados com
acidentes -, mas também se a parte aversa ao risco o suporta. Segue-se que, sob
uma solução socialmente ideal para o problema dos acidentes, duas coisas serão
verdade: ou as partes avessas ao risco não se engajarão em atividades de risco
socialmente desejáveis ou não suportarão os riscos, o que quer dizer, os riscos serão
distribuídos mediante contratos de seguro ou serão deslocados para a parte neutra a
ele (SHAVELL, 2003, Capítulo 5 - p.2).

A solução para o problema da alocação dos riscos de acidentes pode ser obtida com o deslocamento do risco da parte avessa para a parte neutra a ele, ou com a sua repartição entre as partes, situação que reduz a magnitude dos danos para ambas (BATTESINI, 2011, p.171). Em tal contexto, os mecanismos de distribuição e de alocação de riscos, em especial o sistema de responsabilidade civil e de seguro, exercem um importante papel. Assim, serão analisados os efeitos da combinação de ambos os sistemas sobre a conduta das partes.

Diante da ausência de responsabilidade e de seguro, o autor não assume os riscos, logo, não terá incentivos para reduzi-lo. A vítima, por sua vez, arcará com as perdas decorrentes de acidentes. Em tal hipótese, a alocação de riscos socialmente desejável exigiria que o autor fosse avesso ao risco e a vítima neutra a ele.

Sob a regra de responsabilidade subjetiva e na ausência de seguro, a conclusão é semelhante à anterior. Quando o autor adota as medidas de precaução exigidas, os riscos são direcionados para a vítima. Nesse sentido, a alocação eficiente de risco exigiria que o autor fosse avesso ao risco e a vítima neutra a ele.

\footnotetext{
${ }^{88}$ Uma pessoa com aversão ao risco considera uma situação envolvendo 5\% de chance de perder 20.000 pior que uma envolvendo $10 \%$ de chance de perder 10.000, enquanto uma pessoa neutra ao risco será indiferente (BATTESINI, 2011, p. 171).
} 
Quando se tratar de regra de responsabilidade objetiva, em contexto de ausência de seguro, os riscos serão direcionados para o autor. Logo, a alocação de riscos será eficiente se o autor for neutro ao risco e a vítima avessa a ele. Geralmente, as empresas são neutras ao risco, uma vez que o seu patrimônio costuma ser expressivo quando comparado com as perdas esperadas com acidentes (SHAVELL, 2003, Capítulo 5 - p.2). Se o autor for avesso ao risco, ele "pode ser conduzido a adotar um nível de precaução excessivo", bem como "pode ser desencorajado a se engajar em atividades com risco de acidentes socialmente desejáveis" (SHAVELL, 2003, Capítulo 5 - p.3).

Os incentivos criados pelas regras de responsabilidade civil são alterados quando autor e vítima podem obter seguro contra acidentes ${ }^{89}$. Para a análise que se segue, considere que o seguro é acessível às partes e proporciona cobertura integral dos danos.

Sob as regras de ausência de responsabilização ou de responsabilidade subjetiva, os efeitos da alocação de risco sobre a vítima avessa a ele serão amenizados pela cobertura proporcionada pelo seguro (BATTESINI, 2011, p.174).

Por outro lado, quando a responsabilidade é objetiva, a vítima já se encontra implicitamente assegurada pelo sistema normativo, uma vez que os riscos de acidente são suportados pelo autor (SHAVELL, 2003, Capítulo 5 - p.4). Em tal contexto, se o autor for avesso ao risco, celebrará um contrato de seguro. Os efeitos da responsabilidade objetiva sobre a alocação de risco também serão amenizados pela cobertura proporcionada pelo seguro.

Conclui-se que, se o seguro é perfeito e acessível às partes, qualquer regime de responsabilidade civil adotado será eficiente quanto à alocação do risco, uma vez que o seguro afasta o risco da parte que é avessa a ele. No entanto, é um sistema que tem eficácia relativa:

Em geral, o seguro transfere os riscos da parte segurada para a seguradora. Transferir é outro nome para externalizar. A externalização do risco dá ao segurado um incentivo para reduzir suas precauções. A indústria de seguros chama a redução da precaução causada pelo seguro de risco moral ${ }^{90}$ (COOTER; ULEN, 2010, p. 368).

As partes que dispõem de seguro contra acidentes tendem a adotar um nível de precaução inferior ao que adotariam caso tivessem que arcar com os danos. Esse efeito é

\footnotetext{
${ }^{89}$ De acordo com Cooter e Ulen, “o seguro é um sistema privado de direito da responsabilidade civil que realoca os custos de acidentes de acordo com contratos entre segurados e seguradoras" (COOTER; ULEN, 2010, p. 367). Duas espécies de seguro serão consideradas. A primeira modalidade será um seguro para a vítima, ou seja, cobrirá os seus eventuais danos. Nesse sentido, se a vítima for avessa ao risco, ela contratará a cobertura completa. A segunda modalidade será um seguro para o autor, ou seja, cobrirá as suas despesas quando reconhecida a sua responsabilidade. Se o autor for avesso ao risco, ele contratará a cobertura contra responsabilidade.

${ }^{90}$ As seguradoras usam diversos métodos para reduzir o risco moral, especialmente aumentar as franquias e prêmios. Apesar de reduzirem o risco moral, nenhum consegue eliminá-lo. Além disso, tais mecanismos acabam por afastar os riscos bons e manter os riscos ruins, fenômeno denominado de "seleção adversa" (COOTER; ULEN, 2010, p. 369).
} 
socialmente indesejável, pois enfraquece os incentivos criados pelo sistema de responsabilidade civil quanto à adoção dos níveis ótimo de precaução e de atividade.

\subsubsection{Custos administrativos}

O terceiro pressuposto a ser flexibilizado considera que as partes envolvidas em atividades com risco de acidentes não são influenciadas pelos custos $\operatorname{administrativos}^{91}$ ao tomarem suas decisões. Contudo, tais custos, além de representarem um dispêndio substancial de recursos, afetam os incentivos criados pelas regras de responsabilização. Cabe ressaltar que o valor total dos custos administrativos dependerá do número de acidentes e dos custos unitários de resolução ${ }^{92}$.

Diante da ausência de responsabilização, tendo em vista que os danos que recaem sobre a vítima não são realocados, não há a incidência de custos administrativos. Por outro lado, a aplicação das regras de responsabilidade subjetiva e objetiva implica custos.

O número total de ações tende a ser maior sob o regime de responsabilização objetiva quando comparado com o de responsabilização subjetiva. Sob o primeiro regime, a vítima terá incentivos para reivindicar indenização sempre que o seu prejuízo exceder os custos esperados com o processo. Sob o segundo regime, a vítima não terá incentivos para ajuizar uma ação com tanta frequência, visto que terá que provar a culpa do autor.

No entanto, a média de custos administrativos despendidos por ação tende a ser maior diante de um regime de responsabilização subjetiva, pois, como mencionado, há um elemento adicional, a culpa do autor, cuja prova pode conduzir a desentendimentos maiores. Steven Shavell salienta que a comparação da magnitude dos custos administrativos diante de uma regra ou outra é ambígua em termos teóricos:

\footnotetext{
Alguns diriam que, sob a regra de responsabilidade objetiva, haveria um número maior de ações, mas outros sustentariam que a média de custos envolvidos na resolução de casos sujeitos à regra de responsabilidade subjetiva é maior diante da grande probabilidade de serem levados a julgamento e de demandarem uma resolução mais dispendiosa (SHAVELL, 2003, Capítulo 5 - p.4).
}

\footnotetext{
${ }^{91}$ Os custos administrativos podem ser entendidos como os custos (legais ou não) com os quais as partes deverão arcar para solucionar os seus conflitos, o que inclui os custos de oportunidade, as despesas com advogado, os gastos para acionar o Poder Judiciário, entre outros. Tais custos serão despendidos não apenas em casos que vão a julgamento, mas também naqueles em que as partes decidem entrar em um acordo fora da esfera judicial.

${ }_{92}$ Associados à forma de resolução do conflito, se negocial (acordo ou sistema de seguro) ou se litigiosa (via sistema judicial de responsabilidade civil). A primeira se revela menos onerosa do que a segunda (BATTESINI, 2011, p. 179).
} 
Os custos administrativos associados ao sistema de responsabilidade civil são altíssimos. Nesse sentido, o emprego de regras de responsabilização só será considerado socialmente desejável se os benefícios sociais dele resultantes (como a redução do número de acidentes) excederem os seus respectivos custos administrativos (SHAVELL, 2003, Capítulo $5-\mathrm{p} .4)$. 


\section{$4 O$ papel da responsabilidade civil}

A teoria econômica defende que, a partir da análise de tais modelos, é possível compreender o funcionamento de um sistema de responsabilidade civil, bem como avaliá-lo. Além disso, a análise econômica da responsabilidade civil se propõe a examinar a estrutura do sistema jurídico, a fim de formular regras que contribuam para a consecução de objetivos socialmente relevantes, dentre eles, a prevenção de acidentes. Alia-se à teoria jurídica, mas inova ao defender novas funções e metas para esse instituto de direito privado.

\subsection{A função desempenhada pela responsabilidade civil sob a perspectiva da teoria jurídica}

Todo sistema de responsabilidade civil deve ter uma razão de ser, ou seja, deve desempenhar um papel. A teoria jurídica aponta duas funções essenciais da responsabilidade civil: a reparação e a prevenção. Duas outras atribuições também são consideradas: a punitiva e a informativa.

Embora a teoria jurídica reconheça a existência dessas outras atribuições, a reparação dos danos desempenha um papel central no sistema de responsabilidade civil. No passado, "nada parecia mais lógico, mais racional ou mais justo do que determinar que quem causasse a outrem um dano teria o dever de o reparar" (MORAES, 2007, p. 205). Ainda hoje, a compensação da vítima é considerada o principal objetivo desse campo do direito privado:

O anseio de obrigar o agente, causador do dano, a repará-lo inspira-se no mais elementar sentimento de justiça. $\mathrm{O}$ dano causado pelo ato ilícito rompe o equilíbrio jurídico-econômico anteriormente existente entre o agente e a vítima. Há uma necessidade fundamental de se restabelecer esse equilíbrio, o que se procura fazer recolocando o prejudicado no status quo ante. [...] Observa o insigne Antônio Montenegro que a teoria da indenização de danos só começou a ter uma colocação em bases racionais quando os juristas constataram, após quase um século de estéreis discussões em torno da culpa, que o verdadeiro fundamento da responsabilidade civil devia-se buscar na quebra do equilíbrio econômico-jurídico provocado pelo dano (CAVALIERI FILHO, 2010, p.13)

É importante ressaltar que, durante muito tempo, a obrigação de reparar tinha sua origem na culpa do autor ${ }^{93}$. Atualmente, não há que se falar em indenização sem a existência

\footnotetext{
${ }^{93}$ Maria Celina Bodin de Moraes faz interessante colocação acerca da responsabilidade por ato ilícito durante os séculos XVIII e XIX: “[...] a responsabilidade, enquanto noção jurídica, somente poderia existir quando derivada de comportamento voluntário, negligente ou doloso, do agente ofensor. A partir de então, a teoria do ato ilícito, qual manifestação da vontade humana, correlacionou-se, íntima e estruturalmente, às concepções vigentes de justiça e liberdade. Sendo o ato uma afirmação de liberdade, ele será 'ilícito' onde comece a liberdade do outro"
} 
de dano. Pode existir responsabilidade sem culpa, mas não pode haver responsabilidade sem dano $^{94}$ (CAVALIERI FILHO, 2010, p. 73).

A responsabilidade civil, além de permitir a compensação da vítima por eventuais prejuízos que venha a suportar, também atua na prevenção de danos. A função preventiva é considerada por muitos autores como um efeito colateral benéfico do sistema de responsabilização ${ }^{95}$.

Em consonância com os demais propósitos da responsabilidade civil, a teoria jurídica vislumbra ainda uma outra função: a punitiva. Eugênio Battesini sustenta que a punição consistiria na imposição ao autor de ônus pecuniário adicional aos danos efetivamente verificados $^{96}$ (BATTESINI, 2011, p. 105). Entretanto, alguns autores afirmam que a reparação do dano já conta com um duplo aspecto: um compensatório, para confortar a vítima, e um punitivo, cujo objetivo é "impor uma penalidade exemplar ao ofensor, constituindo esta na diminuição de seu patrimônio material e na transferência da quantia para o patrimônio da vítima" 97 (MORAES, 2007, p. 219).

Sustenta-se que as funções compensatória e punitiva se aliam para prevenir a ocorrência de danos. Muitos autores defendem que esta última atribuição da responsabilidade civil se distinguiria das demais por se vincular a um objetivo utilitarista, a prevenção de danos futuros e não a retribuição de danos passados (MORAES, 2007, p. 225-226).

Por fim, a teoria jurídica também destaca o papel informativo da responsabilidade civil. Nesse sentido, o sistema de responsabilização, ao estabelecer parâmetros de conduta, forneceria informações acerca dos comportamentos adequados a serem adotados.

\footnotetext{
(MORAES, 2007, p. 199). Acrescenta que "a liberdade então, era a razão mesma da responsabilidade; se não há ato de vontade, não há responsabilidade" (MORAES, 2007, p. 199).

${ }^{94}$ Segundo Maria Celina Bodin de Moraes, Orlando Gomes chama tal mudança na teoria da responsabilidade civil de "giro conceitual do ato ilícito para o dano injusto", o que permitiu a reparação de outros danos que não aqueles decorrentes da prática de um ato ilícito (MORAES, 2007, p. 177).

95 "Em matéria de responsabilidade civil, a prevenção é um epifenômeno da reparação dos danos, pois se desestimula comportamentos ou resultados danosos com a sua atribuição aos seus responsáveis" (LOPES, 2006, p. 343).

${ }^{96} \mathrm{O}$ que remete a ideia dos punitives damages, comuns na tradição do Common Law.

${ }^{97}$ Pontes de Miranda não concorda com tal entendimento. Em trecho citado por Maria Celina Bodin de Moraes, o referido autor sustenta que “a teoria da responsabilidade pela reparação dos danos não há que se basear no propósito de sancionar, de punir, as culpas, a despeito de se não atribuir direito à indenização por parte da vítima culpada. O fundamento, no direito contemporâneo, está no princípio de que o dano sofrido tem que ser reparado, se possível. A restituição é que se tem por fito, afastando qualquer antigo elemento de vingança. [...] em sentido amplo, indenização é que se há de prestar para se pôr a pessoa na mesma situação patrimonial, ou, por incremento do patrimônio, no mesmo estado pessoal em que estaria se não houvesse produzido o fato ilícito [...]. O juiz que condena à reparação não pune [...] (MIRANDA apud MORAES, 2007, p. 261-262). Muitos autores demonstram certa resistência a ideia de função punitiva da responsabilidade civil, pois, para eles, a punição é tarefa do Direito Penal.
} 


\subsection{A função desempenhada pela responsabilidade civil sob a perspectiva da teoria econômica}

Os modelos descritos no capítulo anterior evidenciam que a análise de custos permeia toda a teoria econômica da responsabilidade civil. Como mencionado anteriormente, em contexto de acidentes, os custos de transação são bastante elevados, o que inviabiliza a negociação prévia (acerca da adoção de medidas de prevenção adequadas, entre outras coisas) na maior parte dos casos. Diante de tal hipótese, torna-se indispensável a utilização de outros mecanismos para solucionar os problemas das externalidades negativas criadas pelas atividades que envolvem risco de acidentes. Dentre eles, Eugênio Battesini destaca a regulamentação administrativa, as sanções criminais, os instrumentos de natureza tributária, o sistema de seguro e o sistema de responsabilidade civil (BATTESINI, 2011, p. 101).

$\mathrm{O}$ referido autor os distingue de acordo com o momento de atuação. Tais mecanismos podem produzir efeitos ex ante ou ex post à ocorrência do dano (externalidade negativa). Na atuação ex ante, destaca Battesini, o principal propósito é prevenir os danos, como ocorre na regulamentação administrativa e nos direitos de propriedade. Já na atuação ex post, busca-se a sua reparação, é o caso dos sistemas de responsabilidade civil e de seguro ${ }^{98}$ (BATTESINI, 2011, p. 102).

De acordo com a teoria econômica, embora a responsabilidade civil também atue na reparação dos danos, sua principal atribuição se dá no âmbito da prevenção de acidentes. Entende-se que é melhor prevenir o dano para que não seja necessário repará-lo. Nesse sentido, Battesini ressalta que:

\footnotetext{
Sob o ponto de vista social, constata-se que, efetivada a reparação, o dano proporcionado pelo acidente não deixa de existir, ele apenas é trasladado da vítima para o autor. Não havendo o real retorno à situação anterior, mas a mera transferência do dano, Hans-Bernd Shäfer e Claus Ott consignam que "o princípio da compensação não é suficiente como guia" para um sistema de responsabilidade civil [...] (BATTESINI, 2011, p.104).
}

Steven Shavell ressalta que o propósito da responsabilidade civil, sob a concepção tradicional, é a compensação da vítima. Acrescenta que, raramente, alguém sustenta que a sua principal função seja dissuadir certas condutas. Ainda assim, ele defende que a redução do risco de acidentes por meio de tal dissuasão é o seu verdadeiro propósito (SHAVELL, 2003, Capítulo $5-$ p.8).

\footnotetext{
${ }^{98}$ A aplicação de cada mecanismo dependerá de um conjunto de circunstâncias, dentre elas, o nível de informação do Poder Público e os custos com sua implementação.
} 
Quando o referido autor fala em "propósito" de um sistema de responsabilidade civil, ele quer dizer a diferença que tal sistema pode fazer em termos de resultados. Nesse sentido, a reparação dos prejuízos suportados pela vítima não pode ser considerada o principal objetivo de um regime de responsabilização, uma vez que o sistema de seguro, público ou privado, também pode compensá-las por eventuais danos que venham a ocorrer. Portanto, a principal diferença que o sistema de responsabilidade pode fazer, em termos de resultados, é criar incentivos para a segurança e, como evidenciado nos modelos econômicos, pode gerá-los independentemente da existência ou não de seguro (SHAVELL, 2003, Capítulo 5 - p.9).

Santos Pastor, em trecho citado por Eugênio Battesini, sustenta que, atualmente, o valor de um sistema de responsabilidade civil deve ser aferido pelos resultados obtidos no desempenho de sua função preventiva ${ }^{99}$, bem como nas situações em que os demais mecanismos de compensação não conseguem atuar ou, atuando, sejam inferiores (BATTESINI, 2011, p.107). Sob a perspectiva econômica, o sistema de responsabilização cria incentivos para que as partes envolvidas em atividades com risco de acidentes invistam em prevenção, desenvolvam atividade em um nível que atenda aos interesses sociais e obtenham informações adequadas sobre o risco.

Alguns autores tratam da função preventiva da responsabilidade civil sob uma abordagem mais ampla, a partir da análise de custos. Robert Cooter e Thomas Ulen defendem que:

A finalidade econômica da responsabilidade civil é induzir os autores e vítimas de
lesões a internalizarem os custos do dano que pode ocorrer em consequiência da falta
de cuidado. O direito da responsabilidade civil internaliza esses custos fazendo o
causador da lesão indenizar a vítima. Quando os autores de atos ilícitos em potencial
internalizam os custos do dano que causam, eles têm incentivos para investir em
segurança no nível eficiente. A essência econômica do direito da responsabilidade
civil consiste em seu uso da responsabilização para internalizar externalidades
criadas por custos de transação elevados (COOTER; ULEN, 2010, p. 322).

A teoria econômica sustenta que o sistema de responsabilidade civil desempenha uma função de bem-estar social que se caracteriza por maximizar o benefício líquido proporcionado pelas atividades que envolvam risco (o benefício total proporcionado à sociedade deduzidos os custos sociais dos acidentes). Nesse sentido, Guido Calabresi sustenta que qualquer sistema de responsabilidade civil tem por fim a consecução de duas metas: a justiça e a redução dos custos dos acidentes. Esta, de acordo com ele, seria a sua principal função.

\footnotetext{
${ }^{99}$ É importante destacar que a função preventiva não constitui exclusividade do sistema de responsabilidade civil. A regulamentação administrativa em matéria de segurança também é um mecanismo eficiente para a redução de acidentes.
} 
A meta de minimizar a soma dos custos com precaução e dos danos esperados pode ser dividida em três sub-objetivos ${ }^{100}$. O primeiro é a redução do número e da severidade dos acidentes. Calabresi o denomina de redução primária de custos. Acrescenta que pode ser alcançada de duas maneiras: mediante a proibição de certas atividades que possam causar acidentes, ou, tornando-as mais "caras"101 e, portanto, menos atrativas, de acordo com a extensão dos danos que ensejam. O segundo, denominado redução secundária de custos, diz respeito à minimização dos encargos sociais (algo mais amplo, como os custos de

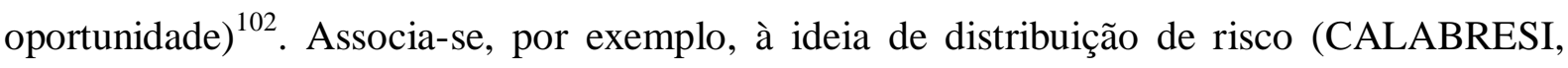
1970, p.27).

De acordo com a teoria econômica, as regras de responsabilização não visam apenas à redução dos riscos de acidentes, mas também a sua alocação e distribuição. Fábio Ulhoa afirma que a responsabilidade objetiva, por exemplo, cumpre a função específica de socializar custos de certas atividades (COELHO, 2010, p.286).

Guido Calabresi inclui a compensação da vítima na análise da redução secundária dos custos. Contudo, ressalta que, embora tenha utilizado a expressão "secundária", não quer dizer que está depreciando a sua importância. Ele assevera que não há dúvidas de que a forma como as vítimas são compensadas após a ocorrência do dano seja crucial. Essa redução só é dita secundária no sentido de que somente será considerada quando as medidas adotadas na redução primária (prevenir acidentes) falharem (CALABRESI, 1970, p.28).

Por fim, trata do terceiro sub-objetivo, denominado de redução terciária de custos, que envolve a minimização dos custos administrativos. Diz-se "terciária" porque a sua finalidade é diminuir os custos envolvidos na consecução das duas primeiras metas.

Essas metas, muitas vezes, são incompatíveis. Por exemplo, há um certo ponto em que a redução do número de acidentes gera custos superiores aos que economiza. Nesse sentido, é importante destacar que "uma sociedade não almeja evitar a ocorrência de acidentes a qualquer custo, mas sim controlar os custos dos acidentes de maneira consistente com o conjunto de objetivos sociais" (BATTESINI, 2011, p. 51). Assim, Calabresi sustenta que o sistema de responsabilidade, ou outro mecanismo de atuação sobre acidentes, deve buscar a melhor combinação das reduções primária, secundária e terciária, considerando que algo será abdicado para que tal minimização de custos seja alcançada (CALABRESI, 1970, p. 29).

\footnotetext{
${ }^{100}$ Calabresi sustenta que essa divisão é apenas analítica, pois o principal objetivo é minimizar os custos dos acidentes de maneira justa (CALABRESI, 1970, p.31).

101 "Caras" no sentido de que a utilidade de tais atividades pode ser reduzida diante dos custos que impõem.

${ }^{102}$ Calabresi sustenta que os economistas, ao contrário dos juristas, tendem a tratar a redução secundária dos custos como "justiça". A razão é que esse exame usualmente ingressa no campo da comparação interpessoal de utilidade e assim não é passível de ser objeto da análise econômica tradicional. Ele acrescenta que optou por tratar como "redução de custo" porque o que pode ser dito acerca dessa abordagem é muito mais concreto do que pode ser dito sobre um conjunto de objetivos tratado como justiça (CALABRESI, 1970, p. 28).
} 


\subsection{Qual é o verdadeiro propósito da responsabilidade civil?}

Muitos teóricos do direito têm concentrado suas investigações sobre a responsabilidade civil. Uma das principais questões levantadas diz respeito ao fundamento ético-jurídico desse campo do direito privado. "Terá tal fundamento passado a ser o da solidariedade social, cumprindo postulados de justiça distributiva, ou, ao invés, deve-se considerar inalterado o seu núcleo essencial, consistente na tradicional função ressarcitória, atinente à justiça retributiva?” (MORAES, 2007, p. 324)

Esta pergunta enseja uma interessante discussão acerca do papel da responsabilidade civil proposto pela análise econômica e a correspondente resistência que tem enfrentado no meio acadêmico.

Guido Calabresi sustenta que os dois principais objetivos de um sistema de responsabilidade civil são a justiça e a redução de custos com acidentes. Essa dicotomia fomentou uma polarização dos teóricos em torno de duas concepções: a de justiça corretiva e a de justiça distributiva ${ }^{103}$. Cada uma reserva um papel distinto para a Economia no estudo do Direito $^{104}$.

Como ressalta Steven Shavell, a maioria dos acadêmicos, juízes e até dos cidadãos assume que a compensação justa da vítima é a principal função de um sistema de responsabilidade. Tanto que as vítimas, ao ajuizarem suas ações, buscam, em grande medida, a reparação dos danos que sofreram. Isso revela um apelo, quase que intuitivo, à noção de justiça corretiva, de que o ofensor deve compensar a sua vítima, pelo menos sob a regra de responsabilidade subjetiva (SHAVELL, 2003, Capítulo 5 - p.8).

Atualmente, duas correntes modernas de estudo da responsabilidade civil se destacam no meio acadêmico. Uma delas é formada por aqueles que defendem que o sistema de responsabilização busca a dissuasão do risco, que compreendida de forma mais ampla, remete à ideia de prevenção. A outra é formada por aqueles que acreditam que o sistema de responsabilidade civil é um meio para a realização de justiça corretiva entre as partes.

\footnotetext{
${ }^{103}$ A justiça corretiva considera como unidade básica de análise a relação jurídica privada, preocupando-se com o restabelecimento do equilíbrio interno violado pelo acidente. Este, por sua vez, será alcançado mediante a trasladação do dano da vítima para o autor. Assim, sob a perspectiva da justiça corretiva, a responsabilidade civil atua como um mecanismo de compensação de danos. A justiça distributiva, por outro lado, transcende a relação jurídica privada, pois se volta para a forma com que os recursos são distribuídos em sociedade. Nesse sentido, preocupa-se com a distribuição eficiente dos custos sociais dos acidentes, considerando as condições de cada indivíduo para evitar o risco, de modo que aquele que tem maiores chances de evitá-lo deve arcar com a maior parte dos custos. Portanto, sob a perspectiva da justiça distributiva, o sistema de responsabilização atua como mecanismo de distribuição de riscos e a busca do restabelecimento do equilíbrio interno da relação privada ocupa um segundo plano diante de outros objetivos socialmente desejáveis (BATTESINI, 2011 , p. 116 117).

${ }^{104}$ De acordo com Eugênio Battesini, a primeira reserva um papel subsidiário à Economia. A segunda, por outro lado, reserva-lhe um papel mais destacado, pois o conhecimento econômico será indispensável na formulação e na estruturação dos objetivos almejados por um sistema de responsabilidade civil (BATTESINI, 2011, p. 117).
} 
Até meados da década de 70, os propósitos da responsabilidade civil não eram objeto de discussão entre os acadêmicos. Frequentemente, as regras de responsabilização se justificavam em termos de justiça, tipicamente tratada como algo intuitivo (SCHWARTZ, 1997, p. 1.802). Anos mais tarde, no entanto, esse cenário mudou. Surgiu o interesse pelas teorias que interpretavam a responsabilidade civil como uma expressão do que Aristóteles denominava de justiça corretiva. Defensores mais recentes dessa corrente têm oferecido interpretações mais extensivas com base nos trabalhos de filósofos morais como Kant e Hegel.

Surgiram também aqueles que enfatizavam a dissuasão (prevenção) como o principal objetivo da responsabilidade civil. Eles faziam parte de um novo movimento que surgia: a Análise Econômica do Direito. Contudo, o propósito da dissuasão não despertou o interesse dos estudiosos dessa área do direito privado. Os autores que insistiam em defender esse aspecto da responsabilidade civil "nadavam contra a corrente" (SCHWARTZ, 1997, p.1805).

No entanto, os trabalhos de Guido Calabresi e Richard Posner, que propunham a aplicação de princípios econômicos à análise normativa das regras de responsabilidade, chamaram a atenção de muitos. Em contrapartida, autores como George Fletcher, Richard Wright, Richard Epstein, Ernest Weinrib e Jules Coleman se propuseram a fazer uma análise moral da responsabilidade civil, em clara oposição à teoria econômica.

Eles sustentam que a abordagem econômica, com destaque para a eficiência, é moralmente obtusa e que a própria estrutura do sistema de responsabilização refuta qualquer entendimento de que a dissuasão seja um objetivo adequado ${ }^{105}$ (SCHWARTZ, 1997, p.1807). Outros autores, entretanto, apenas demonstraram um interesse passageiro pela nova proposta.

Por outro lado, a justiça corretiva também foi negligenciada ou, até mesmo, desprezada por muitos adeptos da teoria econômica da responsabilidade civil ${ }^{106}$. Alguns sustentam que o sistema de responsabilização não deve se apoiar em um "senso de justiça" ou em imperativos morais. Outros defendem que a justiça corretiva perdeu espaço como propósito primordial da responsabilidade civil diante do crescimento do sistema de seguros (SCHWARTZ, 1997, p.1808). Tais considerações renderam diversas críticas por parte da corrente oposta.

\footnotetext{
${ }^{105}$ Fletcher e Epstein sustentam que a análise econômica, como um todo, não é apenas incompleta, mas também equivocada ((SCHWARTZ, 1997, p.1815).

${ }^{106}$ Gary Schwartz destaca que a metodologia econômica de analisar os problemas a partir da noção de eficiência e de classificar seus demais elementos como apenas questões que envolvem a distribuição de riqueza, apesar de dar destaque para considerações acerca da justiça distributiva, tende a desconsiderar a possibilidade de realização de justiça corretiva. Essa desconsideração provoca revolta entre os defensores da corrente oposta (SCHWARTZ, 1997, p.1809).
} 
Weinrib e Coleman sustentam que, uma vez reconhecida a responsabilidade civil como expressão da justiça corretiva, a estrutura do sistema de responsabilização mostrar-se-á incompatível com a racionalidade presente na ideia de dissuasão. Tal conclusão decorre da análise que fizeram de várias características estruturais do sistema de responsabilidade civil $^{107}$.

Gary Schwartz ressalta que é possível separar dois aspectos de suas observações, um positivo e um negativo. O primeiro diz respeito ao fato de que a justiça é inerente à estrutura do sistema de responsabilidade. O segundo é que a prevenção não deve ser considerada um objetivo relevante. De acordo com o referido autor, a primeira afirmação está correta e qualquer esforço para desconsiderar a justiça é injustificado e insatisfatório (SCHWARTZ, 1997, p.1.816). A maior parte das pessoas ainda compreende o sistema de responsabilidade civil em termos morais, como um mecanismo para identificar e combater condutas consideradas erradas.

Entretanto, o aspecto negativo - o de que a prevenção não pode ser considerada um dos propósitos da responsabilidade civil - não faz sentido. Para a teoria econômica, o importante não é determinar quem arcará com o dano, mas evitar que este ocorra em primeiro lugar. Ou melhor, o essencial não é a imputação da responsabilidade ex post, mas a perspectiva de responsabilização ex ante. Se o potencial autor pode prever a sua responsabilização em certas situações, esta perspectiva terá sobre ele um efeito positivo em termos de prevenção ${ }^{108}$.

Muitos questionam a capacidade de dissuasão das regras de responsabilidade civil. Gary Schwartz aponta algumas das principais críticas. Uma delas sugere que tais regras são "supérfluas" como mecanismo de desestímulo, pois podem existir outros incentivos para a dissuasão de condutas arriscadas. Por exemplo, pode existir um incentivo moral, ou seja, um indivíduo pode agir de maneira adequada para não criar riscos para outras pessoas, ou até

\footnotetext{
${ }^{107}$ Apontam diversas observações. Primeira, a responsabilidade não será imputada a qualquer pessoa que aja de maneira "ilícita", mas somente àquela cuja conduta produza dano. Isso é compatível com a lógica da justiça, mas se afasta da lógica da prevenção. Segunda, a indenização do autor não é medida pelo risco que ele cria, mas pela extensão do dano sofrido pela vítima. Novamente, isso faz sentido para a lógica da justiça corretiva, mas não para a perspectiva econômica. Terceira, a ação de indenização é ajuizada pela vítima, é ela que leva o caso ao conhecimento do Judiciário, o que faz sentido sob a ótica da justiça corretiva, mas também pode ser explicada em termos econômicos. Na medida em que são dados incentivos para que a vítima ajuíze uma ação, eventualmente, também servirá para fins de dissuasão. Quarta, a responsabilidade recairá sobre a parte cuja conduta "ilícita" tenha causado o dano. Enquanto a exigência do nexo de causalidade é compatível com a teoria da justiça corretiva, para os propósitos econômicos, é um requisito deficiente, pois o foco da imputação deve ser a parte que poderia ter evitado o risco da melhor maneira (best risk avoider), que pode ser ou não a efetiva causadora do acidente (SCHWARTZ, 1997, p.1.814-15).

${ }^{108}$ Gary Schwartz aponta o seguinte exemplo para esclarecer a proposta econômica: "nos casos em que o réu foi claramente negligente na adoção de medidas de prevenção, mas, mesmo assim, não é possível afirmar que o dano teria sido evitado se ele as tivesse adotado. Sob a perspectiva da justiça corretiva, não há uma razão adequada para responsabilizá-lo. Um economista encara essa situação de maneira diferente. Negar a responsabilização de réus negligentes diante de incertezas acerca do nexo de causalidade pode enfraquecer os incentivos criados para a adoção de condutas mais cuidadosas. Em contrapartida, imputar responsabilidade apesar dessas incertezas não en sejaria o problema inverso de excesso de dissuasão (overdeterrence). Ao invés disso, os potenciais autores teriam uma razão a mais para não agirem de maneira inadequada. (SCHWARTZ, 1997, p. 1.817-18)
} 
mesmo para si. Ademais, as regulamentações de segurança já atingiriam esse propósito (SCHWARTZ, 1994, p.382).

Outra crítica sugere que o sistema de responsabilidade civil não seria causa suficiente para a dissuasão, isto é, teria efeitos insignificantes sobre o esforço em se prevenir acidentes. Os seguros, por exemplo, interviria entre o potencial autor e a imputação de responsabilidade de modo a reduzir ou eliminar os incentivos criados pela ameaça de responsabilização (SCHWARTZ, 1994, p.383).

Além disso, ressaltam que a maior parte das condutas negligentes decorre de lapsos inadvertidos, genuinamente acidentais, ou seja, não decorrem da escolha racional dos indivíduos. Logo, as regras de responsabilidade civil não teriam efeito sobre esse grupo de comportamento. Acrescentam ainda que as limitações cognitivas e psicológicas podem impedir que as pessoas atuem de forma racional em face de uma regra de responsabilidade. Por exemplo, elas, simplesmente, desconhecem as regras e suas implicações ou desconsideram a chance de serem responsabilizadas (SCHWARTZ, 1994, p.383).

Gary Schwartz sustenta que tais objeções sobre a eficácia das regras de responsabilidade sobre a prevenção de acidentes revelam como é difícil generalizá-las ${ }^{109}$. Princípios éticos e morais parecem atuar de forma poderosa sobre médicos, mas atuam de maneira distinta sobre motoristas, pois muitos deles não parecem preocupados com o bemestar dos demais. A segurança pessoal, por outro lado, tem um efeito mais intenso sobre eles. Os incentivos de mercado, por exemplo, podem ser mais importantes para os fabricantes de produtos. Embora existam vários outros incentivos, a responsabilidade civil tem a capacidade de fazer com que eles interajam de um modo mais benéfico ${ }^{110}$. Além disso, o sistema de responsabilidade civil pode tirar proveitos das regras previstas nas regulamentações administrativas e vice-versa ${ }^{111}$.

Quanto ao argumento de que o sistema de responsabilização teria seus efeitos atenuados pelo sistema de seguro, é importante ressaltar que muitos dos potenciais autores de danos não são segurados. No que diz respeito às condutas negligentes adotadas de forma inadvertida, Gary Schwartz reconhece que elas não são dissuadidas de maneira perfeita. Entretanto, isso não quer dizer que não possam ser evitadas de maneira alguma. Por exemplo, os defeitos de fabricação de produtos podem decorrer de falhas inadvertidas nas linhas de montagem, mas a maioria deles é detectada pelo controle de qualidade realizado pelos

\footnotetext{
${ }^{109}$ Por exemplo, uma objeção não se aplica da mesma maneira nos contexto de acidente de trânsito e defeito em produtos.

${ }^{110}$ Por exemplo, as ações de indenização geram publicidade, chamando a atenção dos consumidores para os riscos de determinados produtos, o que estimula uma reação positiva do mercado (SCHWARTZ, 1994, p.384)

111 A teoria da negligência evidencia que a responsabilidade civil pode ser um mecanismo de aplicação do disposto nas regras de regulamentação. Isso é comum nos acidentes de trânsito (SCHWARTZ, 1994, p.384).
} 
fabricantes. Ademais, apenas uma parte de todas as condutas que geram dano pode ser classificada como inadvertida $^{112}$ (SCHWARTZ, 1994, p.386).

A capacidade cognitiva e psicológica das pessoas pode ter influência sobre a maneira como irão atuar em situações que envolvam risco. Elas podem subestimá-lo, mas também podem superestimá-lo. Certamente, há aspectos negativos em se superestimar o risco, mas isso não conduzirá a uma falha na adoção de medidas de cuidado.

Alguns teóricos sustentam que a eficácia dissuasiva da responsabilidade civil é ampla tal como sugerida pelos modelos econômicos. Contudo, esse posicionamento mais radical não se sustenta. Prevalece o entendimento de que o sistema de responsabilização não previne os acidentes da maneira como os modelos descrevem, mas, ainda assim, promove significativa dissuasão. Embora o sistema de responsabilidade civil seja considerado imperfeito como mecanismo de prevenção de acidentes, as demais estratégias (como a regulamentação administrativa) também o são.

Saber como a responsabilidade civil atua, em termos de criação de incentivos, exige uma análise empírica. Steven Shavell reconhece que há poucos estudos estatísticos nesse sentido. Entretanto, há uma razão muito mais ampla para o estudo teórico dos efeitos da responsabilidade sobre o comportamento das pessoas $^{113}$ (SCHWARTZ, 1994, p.425).

Superada essa primeira etapa da discussão - se o sistema de responsabilização é eficaz ou não como mecanismo para prevenção de acidentes -, é importante examinar a possibilidade de combinar as atribuições da responsabilidade civil consideradas por ambas as correntes. Gary Schwartz analisou alguns regimes da responsabilidade civil e buscou verificar se eles poderiam ser interpretados a partir da noção de justiça, de prevenção, ou, em alguma medida, da combinação de ambas.

A responsabilidade subjetiva, como mencionado anteriormente, ocupa um papel central no sistema de responsabilidade civil. Para a teoria econômica, a culpa pode ser descrita segundo a Fórmula de Hand, na qual há uma ponderação entre os custos com a prevenção do risco e danos esperados. Sob a perspectiva econômica, essa formulação faz muito sentido, pois cria incentivos eficientes para investimentos adequados em segurança e para a redução de riscos.

Apesar de sua clara implicação econômica, o parâmetro de culpa formulado por Hand também pode ser explicado em termos morais e éticos. Geralmente, os potenciais

\footnotetext{
${ }^{112}$ Os motoristas podem, de maneira distraída, tirar os olhos da pista e causar acidentes. No entanto, dirigir embriagado ou com excesso de velocidade são, frequentemente, escolhas deliberadas dos motoristas.

${ }^{113}$ Gary Schwartz destaca que "muito da análise econômica moderna é um esforço que vale a pena porque, mais do que revelar o impacto das regras de responsabilidade sobre as condutas dos indivíduos no mundo real, promove um estimulante exercício intelectual" (SCHWARTZ, 1994, p.426).
} 
autores de danos arcam com o ônus da prevenção. A escolha deles em adotar ou não medidas de cuidado demonstra se dão um peso maior aos seus próprios interesses ou ao bem-estar dos demais indivíduos. Se optam pela primeira alternativa, a sua conduta pode ser censurada por ser eticamente imprópria ${ }^{114}$ (SCHWARTZ, 1994, p. 1.820).

A responsabilidade objetiva também pode ser explicada a partir da noção de justiça corretiva. A maioria das hipóteses sujeitas às regras desse regime evidencia que a conduta do autor do dano é causa suficiente para a ocorrência de acidentes, ou seja, geralmente, é a parte que detém as melhores condições para evitá-lo, adotando os níveis adequados de cuidado e de atividade ou mesmo se abstendo de realizá-la. Nesses casos, a imposição de responsabilidade objetiva faz sentido tanto sob a perspectiva econômica quanto sob a perspectiva da justiça corretiva (SCHWARTZ, 1994, p.1821).

Fábio Ulhoa Coelho destaca que ambas as regras de responsabilidade civil desempenham a função preventiva, porém, de maneira distinta. Ele ressalta que, para compreender essa diferença, convém examinar as atribuições específicas de cada uma: a responsabilidade subjetiva sanciona atos ilícitos e a objetiva viabiliza a socialização de risco.

A responsabilidade subjetiva visa a coibir condutas negligentes, antissociais. A obrigação de indenizar representa a punição do causador do dano pela prática do ato ilícito ${ }^{115}$, daí decorre a função sancionatória da referida regra. Sob a responsabilidade objetiva, no entanto, o causador do dano pode ser responsabilizado ainda que não tenha incorrido em qualquer ilicitude (COELHO, 2010, p. 285). Muitas vezes, ele atuou de maneira diligente, mas o dano não poderia ter sido evitado. Portanto, sua obrigação de indenizar não pode ser encarada sobre esse viés sancionatório, uma vez que não decorre de uma conduta indesejável. Por outro lado, será considerado responsável pela reparação do prejuízo porque ocupa uma posição econômica que lhe permite socializar os custos com eventuais acidentes ${ }^{116}$.

O referido autor aduz que a sanção imposta pela responsabilidade subjetiva (compensação da vítima) tem por finalidade evitar novos danos da mesma natureza. Por exemplo, o motorista obrigado a reparar o dano decorrente de sua imprudência no trânsito,

\footnotetext{
${ }^{114}$ Em certa medida, os potenciais autores podem ser conduzidos a também levar em consideração o bem-estar dos demais indivíduos.

${ }^{115} \mathrm{Um}$ aspecto importante nesse sentido é o fato de que a indenização, embora deva corresponder ao dano, pode ser nivelada de acordo com a culpa de quem o causou.

${ }^{116}$ Fábio Ulhoa destaca que a responsabilidade civil objetiva cumpre a função específica de socializar custos de certa atividade. Acrescenta que a responsabilidade por acidente de consumo ilustra bem o mecanismo. O referido autor sugere um exemplo: "Pense no fornecimento de energia elétrica, feito por inúmeros cabos que atravessam o País [...] Essa imensa rede, ao mesmo tempo em que proporciona uma imensurável gama de comodidade (desde banho quente diário até operações financeiras via internete) a quase todos os brasileiros, também os expõe a riscos consideráveis. [...] Pois bem, a responsabilidade por indenizar os danos associados ao fornecimento de energia elétrica pode ser imputada à concessionária porque ela ocupa uma posição econômica que lhe permite, sem dificuldade, socializar os custos correspondentes entre os beneficiários do fornecimento. Cada consumidor, ao pagar a sua conta de luz, irá desembolsar um pouco mais pela energia, para que todos tenhamos a garantia de indenização no caso de acidente de consumo. [...] Em consequencia, quem se ben eficia da atividade arca com os riscos a ela associados. A responsabilidade civil objetiva realiza, desse modo, a socialização de custos" (COELHO, 2010, p. 286).
} 
tende, em tese, a se tornar mais cauteloso. Nesse sentido, a função sancionatória pode se expressar também pela ideia de prevenção, desestimulando condutas ilícitas causadoras de prejuízo ao interesse alheio (COELHO, 2010, p. 287). A responsabilidade objetiva, por sua vez, não desempenha tal função.

Fábio Ulhoa sustenta que, aparentemente, por não sancionar condutas, a mencionada regra não apresentaria um caráter preventivo, pois, se nenhum outro comportamento era exigível do autor, a imputação de responsabilidade não teria o efeito de desestimular a conduta originária. Entretanto, essa conclusão não se sustenta. Embora não desempenhe uma função sancionatória, a responsabilidade objetiva previne acidentes à sua maneira:

O mecanismo preventivo é diverso do que opera a responsabilidade subjetiva, mas existe. Em vez de proibir a conduta originadora dos danos e sancionar a transgressão, a lei estimula o agente a buscar a prevenção como meio de redução dos seus custos. Na competição empresarial, todos sabem, estar em condições de vender produto de igual qualidade do concorrente por preço mais baixo é fator decisivo. Se um empresário consegue reduzir a margem estatística de acidentes de consumo inevitáveis associados ao seu produto, ele poderá praticar preço menor que os dos concorrentes que não conseguiram a mesma redução ${ }^{117}$ (COELHO, 2010, p. 288).

Tais considerações evidenciam que a análise dos propósitos da responsabilidade civil não pode considerar o sistema de responsabilização como um todo. Como ressalta Schwartz, é possível que esse campo do direito privado tenha se desenvolvido de forma confusa e desordenada, considerando o propósito de prevenção em algumas ocasiões e de realização de justiça corretiva em outras (SCHWARTZ, 1994, p.1826). Isso não quer dizer que ambos os aspectos não possam ser considerados. É um erro pensar que optar por um deles implica a renúncia do outro.

Para Guido Calabresi, a justiça deve ser um dos objetivos almejados por um sistema de responsabilidade civil ${ }^{118}$. Contudo, não é um propósito igual à minimização de custos. $\mathrm{A}$ justiça funciona como uma espécie de veto ou restrição sobre o que pode ser feito para que tal redução seja atingida. Visto dessa forma, ela é um teste final pelo qual todo sistema de responsabilização deve passar (CALABRESI, 1970, p. 24).

Um sistema injusto não pode ser adotado simplesmente porque previne acidentes ou reduz custos de forma eficiente, bem como não pode ser dito justo por exclusão dos demais.

\footnotetext{
${ }^{117}$ Flavia Portella Püschel destaca que a "responsabilidade objetiva tem um papel preventivo reduzido, quando se aplica a fatos cuja ocorrência independe do comportamento cuidadoso do agente. No entanto, embora não seja possível eliminar todos os riscos, é certo que eles podem ser maiores ou menores, dependendo do modo como a atividade é exercida. O sujeito que controla a fonte de risco pode, por meio de certas medidas, reduzir o risco ao nível mais baixo possível. A imposição de responsabilidade é um incentivo para que ele o faça" (PÜSCHEL, 2005, p. 98)

${ }^{118}$ Entendida por ele de maneira mais ampla, não apenas a justiça corretiva. Ele ressalta que a justiça é o objetivo mais difícil de ser alcançado. Calabresi destaca interessante afirmação de Edmond Cahn. De acordo com esse autor, é muito mais fácil descrever exemplos de injustiça do que exemplos de justiça. Igualmente, é muito mais fácil argumentar que um sistema que ainda não foi testado solucionará algumas injustiças atuais do que prever as injustiças que ele poderá criar (CALABRESI, 1970, p. 24-25)
} 
"Um sistema de redução de custos economicamente ótimo pode ser totalmente ou parcialmente inaceitável por nos parecer injusto e nenhum argumento acerca de sua eficiência faria muito para salvá-lo" (CALABRESI, 1970, p. 26). A justiça não pode ser ignorada na discussão sobre o sistema de responsabilidade civil, pois é necessária a sua estruturação.

Certamente, prevenir acidentes é algo positivo e, muitas vezes, promover a segurança pode ser melhor do que oferecer uma compensação depois que o dano ocorre. Nesse sentido, a teoria econômica tem muito a oferecer. Assim, antes de reparar uma injustiça (um dano injusto) é melhor impedir que ela ocorra. O sistema de responsabilidade civil pode ser encarado sob essa perspectiva instrumental, pelo menos quando se tratar de responsabilidade subjetiva $^{119}$. Essa consequência confere à função de prevenção um importante componente de justiça.

Gregory Keating aponta outro importante aspecto. De acordo com ele, um dos objetivos do sistema de responsabilidade civil é encontrar um equilíbrio adequado entre o direito de liberdade de um potencial autor e o direito à segurança (à integridade física, psíquica e patrimonial) de uma vítima potencial (SCHWARTZ, 1997, p.1.832).

Diante de tais considerações, prevenir acidentes também deve interessar aos defensores da justiça corretiva ${ }^{120}$. Ambos os propósitos de um sistema de responsabilidade civil, realização de justiça e prevenção de acidentes, devem ser compreendidos como complementares e não concorrentes.

\subsection{A existência de um sistema de responsabilidade civil é justificável?}

Como mencionado na seção anterior, um sistema de responsabilidade civil pode se propor a realizar justiça corretiva ou a prevenir acidentes (ou reduzir custos), ou ambos. Contudo, Posner e Landes ressaltam que manter um sistema de responsabilização implica custos altíssimos $^{121}$. A questão que surge é saber se esses custos são justificados por quaisquer vantagens ou benefícios que o sistema venha a trazer.

Se o sistema de responsabilidade civil, de fato, promove a dissuasão de condutas que podem gerar risco, tal como os modelos econômicos sugerem, provavelmente, os seus

\footnotetext{
${ }^{119}$ No regime de responsabilidade subjetiva, na medida em que o sistema de responsabilização previne condutas negligentes, também evita a ocorrência de injustiças.

120 "Moreover, since preventing injustice from occurring seems clearly more desirable - more 'just' - than merely calling for compensation after the fact, this justice dimension in tort law's deterrence function seems especially worthy of respect" (SCHW ARTZ, 1997, p.1.832).

${ }^{121}$ De acordo com eles, "o sistema de responsabilidade civil é um mecanismo de seguro extremamente caro" (LANDES; POSNER, 1987, p. 
benefícios justificariam os seus custos. Contudo, a realidade é diferente. O sistema de responsabilização não é perfeito.

Pode-se afirmar que o sistema de responsabilidade civil também tem promovido a compensação de vítimas de acidentes. Alguns autores sustentam que os seus custos seriam justificáveis diante da possibilidade de realizar justiça corretiva. Entretanto, há uma variedade de fatores que complicam a análise, por exemplo, muitas vítimas acabam insatisfeitas com os resultados dos processos ${ }^{122}$.

Gary Schwartz sustenta que não há uma resposta clara para essa questão ${ }^{123}$. Steven Shavell, por outro lado, sustenta que a função primordial do sistema de responsabilidade civil é reduzir os riscos de acidente. Logo, esta redução deve ser a justificativa para mantê-lo. No entanto, ressalta que os benefícios dele decorrentes não são suficientes para superar os respectivos custos, ou seja, sua conveniência social líquida é questionável. Diante dessa conclusão, aduz que a regulamentação de segurança é uma alternativa disponível para a conquista de tal propósito $^{124}$ (SHAVELL, 2003, Capítulo 5 - p. 9).

Há diversas propostas de reforma. A mais radical propõe a extinção de todo o sistema de responsabilidade. Seus proponentes sustentam que o problema central é como compensar as vítimas adequadamente e de forma barata. De acordo com eles, tal objetivo poderá ser atingido por meio de um seguro social financiado pelo Estado a partir das reservas de impostos. Sugerem a criação de um fundo ${ }^{125}$. Acrescentam que essa alternativa pode, inclusive, ser considerada justa, pois os ricos pagariam impostos mais altos.

A iniciativa mais ousada foi a adotada pela Nova Zelândia, que, em 1974, aboliu o sistema de responsabilidade civil por danos decorrentes de acidentes, substituindo-o por um sistema público de seguro (sistema de socialização de riscos). Coube ao Estado garantir a compensação das vítimas, independentemente da aferição da conduta do autor (MORSELLO, 2006, p.16). Um mecanismo mais célere e mais barato ${ }^{126}$.

\footnotetext{
${ }^{122}$ Gary Schwartz enfatiza que a justiça é algo mais abstrato e que não pode ser equacionada de modo a incluir todas as experiências das vítimas (SCHWARTZ, 1997, p.1.826).

123 "É uma questão aberta saber se os benefícios com a prevenção criada pelo sistema de responsabilidade civil se justificam diante dos custos substanciais com a sua implementação. Igualmente, é uma questão aberta saber se as vantagens obtidas com a realização de justiça corretiva independem de tal justificação" (SCHWARTZ, 1997, p.1.827).

${ }^{124}$ Guido Calabresi vai mais longe e afirma que o sistema de responsabilidade civil tem se mostrado inadequado para a consecução de quaisquer objetivos, inclusive a justiça (SCHWARTZ, 1997, p.1.826).

${ }^{125}$ Eles propõem que parte desse fundo deveria ser composta de recursos recolhidos de impostos específicos sobre atividades que possam causar acidentes (CALABRESI, 1970, p.6)

${ }^{126} \mathrm{O}$ Accident Compensation Act "teve por escopo principal a justa indenização das vítimas de acidentes, sem a necessidade de que fossem instauradas lides processuais. Estas, aliás, consoante análise à época, representavam altos custos, não resultando na denominada justa compensação" (MORSELLO, 2006, p. 16)
} 
Contudo, a experiência neozelandesa não foi positiva. Ainda que a proposta de socialização de riscos fosse compatível com o princípio da solidariedade social ${ }^{127}$, a função preventiva, característica do sistema de responsabilidade civil, foi consideravelmente mitigada, com o consequente aumento dos encargos sociais (aumento dos déficits públicos, dos prêmios de seguro, entre outros). Não havia incentivos para que as pessoas adotassem medidas de precaução. Diante desse cenário, Marco Fábio Morsello conclui que:

Patente, pois, a insubsistência prática do sistema da ampla e exclusiva socialização dos riscos. Deveras, sob o denominado paradigma pós-moderno, emerge efetiva preocupação com a proteção à pessoa e a seus direitos, cabendo ao Estado velar, no âmbito da ordem pública de proteção, por normas robustecedoras do princípio da prevenção [...] (MORSELLO, 2006, p. 20).

O sistema de seguro, social ou privado, pode funcionar como mecanismo mais eficiente para a compensação de vítimas de danos, mas deixa a desejar no que se refere à criação de incentivos para precaução. É importante destacar que os benefícios com prevenção, em casos nos quais há risco de morte ou lesão grave da vítima ou do autor, são incontestáveis. Em tais hipóteses, quaisquer que sejam os custos com o sistema, não pode ser considerado óbvio em que medida eles superam os respectivos benefícios com segurança (SCHWARTZ, 1994, p. 431).

Maria Celina Bodin de Moraes ressalta que "o objetivo a ser perseguido é oferecer a máxima garantia à pessoa humana, com prioridade, em toda e qualquer situação da vida social em que algum aspecto de sua personalidade esteja sob ameaça ou tenha sido lesado" (MORAES, 2007, p. 182). Nesse sentido, um sistema de responsabilização compatível com esse ideal está longe de perder a sua função, pois a responsabilidade civil acabou por se "revelar a forma mais fácil e justa de tutelar a dignidade, isto é, a integridade psicofísica, a solidariedade e a liberdade humana" (MORAES, 2007, p. 185). Na verdade, esse instituto do direito privado é apenas uma das alternativas que se encontra à disposição de uma sociedade para atuar sobre a prevenção de acidentes, cabendo a ela determinar qual é a melhor combinação dos mecanismos disponíveis (sistema de seguro, regulamentação administrativa, entre outros) para a consecução desse objetivo.

\footnotetext{
${ }^{127}$ Maria Celina Bodin de Moraes ressalta que o princípio da solidariedade social decorre da necessidade "imprescindível da coexistência humana" (solidariedade fática). A solidariedade como valor, por sua vez, decorre da consciência de que há interesses comuns, "interesses esses que implicam, para cada membro, a obrigação moral de "não fazer aos outros o que não se deseja que lhe seja feito"” (MORAES, 2007, p.112).
} 


\section{CONSIDERAÇÕES FINAIS}

A Análise Econômica da responsabilidade civil evidencia uma série de questões interessantes e que merecem atenção. Como ressalta Maria Celina Bodin de Moraes, a necessidade de serem pensadas novas soluções para questionamentos novos e antigos é urgente no campo da responsabilidade civil (MORAES, 2007, p. 185). É uma área do saber jurídico repleta de indagações a espera de respostas e a teoria econômica se propõe a responder algumas delas.

Como mencionado, a responsabilidade civil extracontratual é um dos primeiros campos do direito privado analisado com sucesso mediante a utilização de modelos econômicos. A partir destes, a teoria econômica buscou analisar os incentivos criados pelas regras de responsabilização e seus respectivos efeitos sobre a consecução de objetivos socialmente relevantes, dentre eles, a prevenção de acidentes.

A abordagem econômica se propõe a rever certas concepções consideradas pela teoria jurídica da responsabilidade civil, atribuindo, inclusive, um novo sentido a elas. Sob a perspectiva tradicional, a compensação da vítima é a principal função de um sistema de responsabilidade. A perspectiva econômica, por outro lado, reconhece a importância de tal atribuição, mas defende a prevenção de acidentes como o seu propósito primário.

Aqueles que se posicionam a favor da perspectiva jurídica tradicional apontam que não há evidências de que o sistema de responsabilização atue de forma satisfatória sobre a prevenção de acidentes. Já os defensores da perspectiva econômica sustentam que a compensação das vítimas pode ser assegurada por mecanismos alternativos mais eficientes e mais baratos, como o sistema de seguro.

A experiência neozelandesa demonstrou que um sistema de compensação não funciona sozinho, pois não atua sobre a redução dos riscos de acidentes. Isso reforça a função preventiva da responsabilidade civil. Contudo, qualquer sistema de responsabilização que vise tão somente à prevenção de acidentes será considerado insuficiente. A maior parte das pessoas esperam que os seus danos sejam reparados.

Tais atribuições de um sistema de responsabilidade civil não devem ser encaradas como incompatíveis. Não é preciso optar por uma delas. No entanto, é importante reconhecer que a justiça corretiva oferecerá respostas mais satisfatórias em algumas hipóteses e a prevenção em outras. Outro ponto que merece destaque diz respeito fato de que a regras de responsabilização atuam de maneira distinta sobre a prevenção de acidentes. A responsabilidade subjetiva, ao sancionar a prática do ato ilícito, desestimula a sua prática. A 
responsabilidade objetiva, por outro lado, ao tratar a reparação do dano como custo de uma atividade, previne acidentes como medida de racionalidade econômica.

Impedir que os danos ocorram parece ser melhor do que ter que repará-los, mas o sistema de responsabilidade civil não é perfeito, ou seja, não evitará todos os acidentes. Por isso, a prevenção e a compensação devem ser compreendidas como metas complementares e não concorrentes. É importante prevenir a ocorrência de danos ${ }^{128}$, principalmente quando a vida e a integridade física das partes envolvidas são colocadas em risco. Por outro lado, sempre existirão prejuízos a serem reparados. Trata-se apenas de dois momentos distintos de um mesmo processo: prevenir a ocorrência de acidentes; caso a prevenção falhe e um dano venha a ocorrer, deve ser reparado.

Maria Celina Bodin de Moraes sustenta que o "ciclo da responsabilização se completou" (MORAES, 2007, p.326). Ela aduz que a nova configuração do instituto da responsabilidade civil não permite que se confira o mesmo fundamento retributivo, ou exclusivamente ressarcitório, a essa disciplina. Ao contrário, a possibilidade de sua atuação em um plano mais amplo (além da relação privada), considerando o bem-estar social, revelase cada vez mais importante, principalmente, quando a proteção da pessoa humana for um aspecto fundamental a ser considerado. Qualquer sistema de responsabilidade civil que se proponha a cumprir esse ideal sempre terá um papel a desempenhar.

\footnotetext{
${ }^{128}$ Sempre que a sua prevenção se justificar em termos de custos, exceto quando se tratar da hipótese mencionada (risco de morte ou de lesão grave), pois não é tão óbvio em que medida os custos não justificariam os benefícios com segurança.
} 


\section{REFERÊNCIAS}

ALVAREZ, Alejandro Bugallo. Análise Econômica do Direito: Contribuições e Desmistificações. Direito, Estado e Sociedade. v.9. n 29. p. 49-68. jul/dez 2006.

BATTESINI, Eugênio. Direito e Economia: Novos Horizontes no Estudo da Responsabilidade Civil no Brasil. São Paulo: LTr, 2011.

CAVALIERI FILHO, Sergio. Programa de Responsabilidade Civil. 9ª ed. São Paulo: Atlas, 2010.

CALABRESI, Guido. The Cost of Accidents: A Legal and Economic Analysis. Student Edition. New Haven and London: Yale University Press, 1970.

CALABRESI, Guido; HIRSCHOFF, Jon T. Toward a Test for Strict Liability in Torts. Faculty Scholarship Series. The Yale Law Journal. Volume 81. nº 6. May 1972. Disponível em: http://migre.me/70E2r. Data de acesso: 04.11.11.

CALABRESI, Guido; MELAMED, A. D. Property Rules, Liability Rules, and Inalienability: One View of the Cathedral. Harvard Law Review. Volume 85. no 6. April 1972. Disponível no site: https://www.amherst.edu/media/view/123372/original/CalabresiMelamed.PDF. Data de acesso: 24.10.11.

COELHO, Fábio Ulhoa. Curso de Direito Civil. Volume 2. $4^{\text {a }}$ ed. São Paulo: Saraiva, 2010.

COOTER, Robert; ULEN, Thomas. Direito e Economia. Tradução de Luis Marcos Sander e

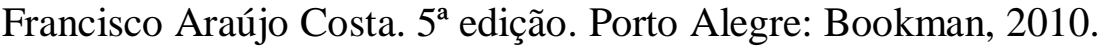

DWORKIN, Ronald. A Visão Econômica do Direito. Uma Questão de Princípio. Tradução de Luís Carlos Borges. São Paulo: Martins Fontes, 2000.

GONÇALVES, Carlos Roberto. Direito Civil Brasileiro: Responsabilidade Civil. Volume

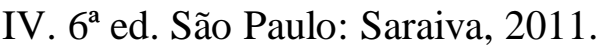

KAPLOW, Louis; SHAVELL, Steven. Property Rules versus Liability Rules: An Economic Analysis. Harvard Law Review. Volume 109. no 4. February 1996. p. 713-790. Disponível em: http://migre.me/70Ep7. Data de acesso: 24.10.11.

LANDES, Willian M.; POSNER, Richard A. The Economic Structure of Tort Law. Cambridge, Massachusetts, and London, England: Harvard University Press, 1987.

LOPES, Othon de Azevedo. Responsabilidade Jurídica: Horizontes, Teoria e Linguagem. São Paulo: Quartier Latin, 2006.

MACKAAY, Ejan. History of Law and Economics. In: BOUCKAERT, Boudewijn; DE GEEST, Gerrit (eds.). Encyclopedia of Law and Economics. Volume 1. University of Ghent: 2000. Disponível no site: http://encyclo.findlaw.com/0200book.pdf. Data de acesso: 08.10.11. 
MORAES, Maria Celina Bodin de. Danos à Pessoa Humana: Uma Leitura CivilConstitucional dos Danos Morais. Rio de Janeiro: Renovar, 2007.

MORSELLO, Marco Fábio. A responsabilidade civil e a socialização do risco. O sistema neozelandês e a experiência escandinava. Revista da Escola Paulista da Magistratura, ano 7 , $\mathrm{n}^{\mathrm{o}}$ 2, p. 13-22, julho/dezembro 2006. Disponível no site: http://www.epm.tjsp.jus.br/FileFetch.ashx?id arquivo=20522. Data de acesso: 10.11.2011.

POSNER, Richard A. Capítulo 12: A abordagem econômica do direito. Problemas de Filosofia do Direito. Tradução de Jefferson Luiz Camargo. São Paulo: Martins Fontes, 2007.

Economic Analysis of Law. $6^{\text {th }}$ edition. New York: Aspen Publishers, 2003.

PÜSCHEL, Flavia Portella. Funções e Princípios Justificadores da Responsabilidade Civil e o art. 927, § único do Código Civil. Revista Direito GV. v.1. n.1. maio/2005. p. 91-107. Disponível no site: http://www.direitogv.com.br/subportais/raiz/RDGV_01_p091_108.pdf. Data de acesso: 10.11.2011.

RODRIGUES, Vasco. Análise Econômica do Direito: Uma Introdução. Coimbra: Almedina, 2007.

SHAVELL, Steven. Strict Liability versus Negligence. The Journal of Legal Studies. Volume 9. $\mathrm{n}^{\mathrm{o}}$ 1. January 1980. p. 1-25. Disponível no site: http://www.er.uqam.ca/nobel/r20310/eco8510/Shavell_JLegStud1980.pdf. Data de acesso: 30.10.11.

Economic Analysis of Accident Law. Foundation of Economic Analysis of Law. Cambridge, MA: Harvard University Press, 2003. Working Paper n. 9694 of National Bureau of Economic Research. Disponível no site: http://www.nber.org/papers/w9694. Data de acesso: 22.09.2011.

SCHWARTZ, Gary T. Reality in Economic Analysis of Tort Law: Does Tort Law really deter? UCLA Law Review. $\mathrm{n}^{\circ}$. 42. 1994. p. 377-444. Disponível no site: http://heinonline.org/HOL/LandingPage?collection=journals\&handle=hein.journals/uclalr42\& $\underline{\text { div }=17 \& \text { id }=\& p a g e}=$. Data de acesso: 31.08 .2011$.

Mixed Theories of Tort Law: Affirming Both Deterrence and Corrective Justice.

Texas Law Review. $\mathrm{n}^{\mathrm{o}}$. 75. 1997. p. 1.801-1.835. Disponível no site: http://heinonline.org/HOL/LandingPage?collection=journals\&handle=hein.journals/tlr75\&div $=63 \&$ id $=\&$ page $=$. Data de acesso: 21.10 .2011 . 